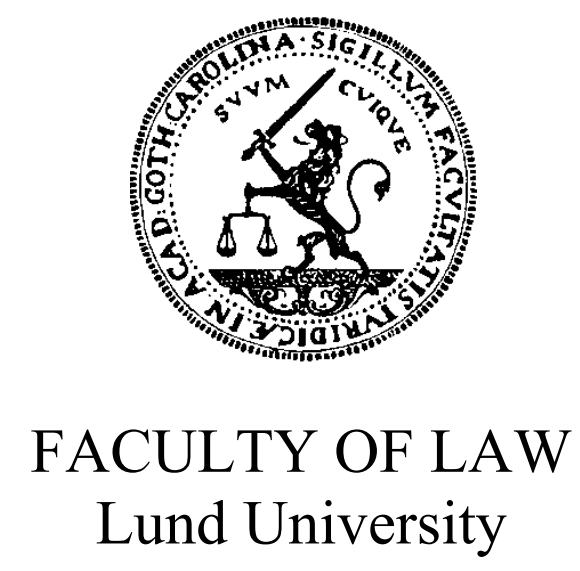

Amanda Bills

\title{
The Relationship Between Third-Party Countermeasures and the Security Council's Chapter VII Powers: Enforcing Obligations Erga Omnes in International Law
}

\author{
JURM02 Graduate Thesis \\ Graduate Thesis, Master of Laws Program \\ 30 Higher Education Credits
}

Supervisor: Britta Sjöstedt

Semester of Graduation: Period 1 Spring Semester 2019 


\section{Contents}

Summary 3

Sammanfattning 4

Acknowledgements $\quad 5$

Abbreviations 6

1 Introduction $\quad 7$

$\begin{array}{ll}1.1 \text { Background } & 7\end{array}$

$\begin{array}{ll}1.2 \text { Purpose and Research Questions } & 10\end{array}$

$\begin{array}{ll}1.3 \text { Delimitations } & 11\end{array}$

$\begin{array}{ll}1.4 \text { Methodology } & 12\end{array}$

$\begin{array}{ll}1.5 \text { Materials and Previous Research } & 14\end{array}$

$\begin{array}{ll}1.6 \text { Structure } & 15\end{array}$

2 Community Interests in International Law 16

$\begin{array}{ll}2.1 \text { Introduction } & 16\end{array}$

2.2 Community Interests in International Law 17

2.2.1 The Emergence of Community Interests 17

2.2.2 Obligations Erga Omnes and Norms Jus Cogens 20

2.2.3 International 'Crimes' in Draft Article 19 [1996] 21

2.3 Community Interests and the UN Charter 22

2.3.1 The UN Charter as a Constitution of the International Community 22

2.3.2 The Security Council under Chapter VII of the UN Charter 24

$\begin{array}{ll}2.4 \text { Conclusion } & 27\end{array}$

3 Third-Party Countermeasures in International Law 29

$\begin{array}{ll}3.1 \text { Introduction } & 29\end{array}$

3.2 Third-Party Countermeasures in the Law of State Responsibility 30

3.2.1 Countermeasures as Enforcement of International Law $\quad 30$

3.2.2 Third-Party Countermeasures in International Law 34

3.3 Third-Party Countermeasures in State Practice 40 
3.3.2 Third-Party Countermeasures in Response to Violations of Human Rights and International Humanitarian Law

3.3.3 Third-Party Countermeasures in Response to Violations of the Prohibition of the Use of Force

3.4 Legal Conditions and Procedural Safeguards 48

4 The Relationship between Third-Party Countermeasures and the Security Council's Chapter VII Enforcement Powers 53

4.1 Introduction 53

4.2 The Relationship between ARSIWA and the UN Charter 55

4.2.1 Primacy of Obligations under the UN Charter 55

4.2.2 Implied Limitations under the UN Charter 58

4.2.3 The Security Council as an Institutional Safeguard 60

$\begin{array}{ll}4.3 \text { Case Studies } & 61\end{array}$

4.3.1 Introduction $\quad 61$

4.3.2 Sudan (1997-present) 63

4.3.2.1 Background 63

4.3.2.2 Security Council Enforcement Measures 64

4.3.2.3 Third-Party Countermeasures 66

4.3.2.4 Analysis $\quad 68$

4.3.3 Libya (2011-present) $\quad 69$

4.3.3.1 Background $\quad 69$

4.3.3.2 Security Council Enforcement Measures $\quad 70$

4.3.3.3 Third-Party Countermeasures 72

4.3.3.4 Analysis $\quad 74$

$\begin{array}{ll}4.4 \text { Conclusion } & 75\end{array}$

5 Conclusion $\quad 77$

Bibliography $\quad 82$

$\begin{array}{lr}\text { Table of Cases } & 106\end{array}$ 


\section{Summary}

This thesis has examined the relationship between third-party countermeasures under the law of state responsibility and UN Security Council enforcement measures under Chapter VII of the UN Charter. Third-party countermeasures are a concept that refers to the use of countermeasures by a state other than the injured state in response to breaches of obligations erga omnes or erga omnes partes, providing states with 'a necessary middle ground between war and words' to enforce the obligations of concern to the international community as a whole. However, the right to take third-party countermeasures is a deeply divisive topic in the law of state responsibility. A significant source of this controversy relates to the uncertain relationship between thirdparty countermeasures and the Security Council's enforcement powers under Chapter VII of the UN Charter. It has been suggested that recognising a regime of third-party countermeasures "would install a "do-it-yourself" sanctions system that would threaten the [collective] security system based on Chapter VII of the Charter of the United Nations', undermining the institutional balance established thereunder. As state practice indicates with increasing clarity that the right to third-party countermeasures is emerging under customary international law, it is necessary to consider in further detail the legal position of such measures in relation to the Security Council's mandate for the maintenance of international peace and security. It is submitted that the right of individual states to take third-party countermeasures is not precluded or subject to other limitations when taken in response to situations where the Security Council is either actively seized with a matter or taking enforcement action under Chapter VII of the UN Charter. In fact, in a number of instances, third-party countermeasures have been taken concurrently with Security Council enforcement measures without coming into conflict with or undermining the effective application of the latter. As such, the risks relating to the use of third-party countermeasures in relation to the Security Council do not appear to have materialised in practice. The uncertain relationship between third-party countermeasures and Security Council enforcement measures therefore appears to be mostly a theoretical or ideological problem without significant risks in practice. 


\section{Sammanfattning}

Denna uppsats har undersökt förhållandet mellan tredjestatskontraåtgärder (på engelska third-party countermeasures) enligt statsansvarsreglerna och FN:s säkerhetsråds mandat att vidta åtgärder mot enskilda stater enligt kapitel VII i FN-stadgan. Tredjestatskontraåtgärder innebär att en stat utan att vara skadad av folkrättsbrottet ifråga vidtar kontraåtgärder mot en annan stat som brutit mot förpliktelser erga omnes eller erga omnes partes. Detta har ansetts utgöra en 'nödvändig medelväg mellan väpnad konflikt och ord' för att upprätthålla vissa gemensamma intressen inom det internationella samfundet. Rätten att vidta tredjestatskontraåtgärder är en djupt kontroversiell och polariserande fråga inom statsansvarsrätten, främst på grund av det osäkra förhållandet mellan tredjestatskontraåtgärder och säkerhetsrådets möjlighet att vidta åtgärder enligt kapitel VII i FN-stadgan. Tredjestatskontraåtgärder har beskrivits som ett allvarligt hot mot det folkrättsliga systemet för kollektiv säkerhet, med påtaglig risk att underminera den institutionella balansen som etablerats i FN-systemet. I takt med att statspraxis av tredjestatskontraåtgärder allt tydligare ger uttryck för en sedvanerättslig rätt till tredjestatskontraåtgärder blir det nödvändigt att närmare överväga hur sådana åtgärder förhåller sig till säkerhetsrådets mandat för upprätthållandet av internationell fred och säkerhet. Slutsatsen av denna är att individuella staters rätt att vidta tredjestatskontraåtgärder inte utesluts eller på annat sätt begränsas när tredjestatskontraåtgärder vidtas i situationer där säkerhetsrådet antingen är engagerat eller har vidtagit åtgärder enligt kapitel VII i FN-stadgan. I själva verket finns det i statspraxis flera exempel på situationer där enskilda stater har vidtagit tredjestatskontraåtgärder samtidigt som säkerhetsrådets har agerat, utan att detta har gett upphov till konflikt eller underminerat säkerhetsrådets mandat. De risker som tidigare påpekats verkar därmed inte ha förverkligats. Det osäkra förhållandet mellan tredjestatskontraåtgärder och säkerhetsrådets mandat för internationell fred och säkerhet under kapitel VII i FN-stadgan framstår snarast som ett teoretiskt och eventuellt ideologiskt grundat problem utan större risker i praktiken. 


\section{Acknowledgements}

This thesis marks the end of my five years as a law student in Lund. I am grateful for all the opportunities I have had during my studies and for the encouragement of friends and family along the way. As one of my close friends in Lund has repeatedly told me throughout our studies (quoting a rather famous anthropomorphic teddy bear), '[y]ou're braver than you believe, stronger than you seem, and smarter than you think'.

First, I would like to thank my supervisor, Britta Sjöstedt, for all her support throughout the different stages of the writing process, from narrowing down my topic to valuable discussions and advice. Thank you for showing confidence in my writing.

My close group of friends in Lund have made these past few years considerably more colourful, whether by arranging elaborate birthday celebrations or simply having lunch together and commiserating about the state of our work. Thank you for your friendship.

My fellow editors at Juridisk Publikation, in particular the editorial team in Lund, have always been a welcome distraction from my studies. I will miss all our intense discussions on various points of law and obscure grammatical rules and being part of such a diverse, intelligent and driven group of law students.

I would also like to thank all friends and colleagues that I have met along the way, from my exchange studies in Lyon, to my internship at the Permanent Mission of Sweden in Geneva, and beyond.

Finally, I would like to thank my extraordinary family for their unwavering support throughout these past years: my parents, for listening to me ramble on about law, and my brother, for all of our end-of-term road trips and adventures in Skåne. I could not have done it without you.

Lund, 15 June 2019

Amanda Bills 


\section{Abbreviations}

\begin{tabular}{|c|c|}
\hline \multirow[t]{2}{*}{ ARSIWA } & Draft Articles on the Responsibility of States for \\
\hline & Internationally Wrongful Acts (2001) \\
\hline \multirow[t]{2}{*}{ ARSIWAC } & Draft Articles on the Responsibility of States for \\
\hline & Internationally Wrongful Acts, with Commentaries (2001) \\
\hline CFSP & European Union Common Foreign and Security Policy \\
\hline EU & European Union \\
\hline GATT & General Agreement on Tariffs and Trade (1994) \\
\hline GATS & General Agreement on Trade in Services \\
\hline $\mathrm{HRC}$ & United Nations Human Rights Council \\
\hline $\mathrm{ICC}$ & International Criminal Court \\
\hline ICCPR & International Covenant on Civil and Political Rights \\
\hline ICJ & International Court of Justice \\
\hline IDI & Institut de droit international \\
\hline ILC & International Law Commission \\
\hline MPEPIL & Max Planck Encyclopedia of International Law \\
\hline NATO & North Atlantic Treaty Organisation \\
\hline OAU & Organisation for African Unity \\
\hline \multirow[t]{2}{*}{ OHCHR } & United Nations Office of the High Commissioner for Human \\
\hline & Rights \\
\hline $\mathrm{OIC}$ & Organisation of Islamic Cooperation \\
\hline PCIJ & Permanent Court of International Justice \\
\hline UN & United Nations \\
\hline UNGA & United Nations General Assembly \\
\hline UNSC & United Nations Security Council \\
\hline UNSCR & United Nations Security Council Resolution \\
\hline UN Charter & Charter of the United Nations \\
\hline US & United States of America \\
\hline YbkILC & Yearbook of the International Law Commission \\
\hline VCLT & Vienna Convention on the Law of Treaties \\
\hline WTO & World Trade Organisation \\
\hline
\end{tabular}




\section{Introduction}

\subsection{Background}

'In reality, article 54 was not about countermeasures: it was about sanctions, it was incompatible with the Charter and it was neither lex lata nor lex ferenda. Perhaps a new category would need to be invented for it: lex horrenda.'

The statement above was made by Mr. Brownlie during the final stages of the ILC's codification of the law of state responsibility, in response to Special Rapporteur Crawford's proposal for a regime of 'collective countermeasures' in the draft Articles on State Responsibility. ${ }^{2}$ The regime of collective countermeasures, subsequently known as third-party countermeasures, ${ }^{3}$ would allow states other than the injured state(s) to resort to countermeasures in response to breaches of obligations erga omnes, or to intervene on behalf of an injured state. ${ }^{4}$ Third-party countermeasures would provide states with 'a necessary middle ground between war and words', 5 and avoid placing 'further pressure on States to intervene in other, perhaps less desirable ways' for the enforcement of collective interests. ${ }^{6}$ The proposal was met with strong criticism in the ILC as well as by states in the Sixth Committee, primarily due to the dangers of allowing a potentially very large group of states the right to intervene in other states' internal affairs and the possibly detrimental effects of such measures on the Security Council's mandate for the maintenance of international peace and security under Chapter VII of the UN Charter. ${ }^{7}$ In the ILC, Mr. Brownlie described the concept of third-party countermeasures as a 'neologism' of international law, a 'completely invented' legal category that 'would install a "do-it-yourself" sanctions system that would threaten the security system based on Chapter VII of the Charter of the United

\footnotetext{
${ }^{1}$ YbkILC (2001), Vol. I, 35, para. 2 (Mr. Brownlie); Brownlie (2008), 515.

${ }^{2}$ Crawford, Third Report on State Responsibility (2000), paras. 105-106.

${ }^{3}$ Dawidowicz (2017), 31-34.

${ }^{4}$ Crawford, Third Report on State Responsibility (2000), 105-106; Crawford (2013), 703-706.

${ }^{5}$ UNGA, Report of the Secretary-General, In Larger Freedom: Towards Development, Security and Human Rights for All (2005), 30, para. 109.

${ }^{6}$ Crawford, Third Report on State Responsibility (2000), para. 405.

${ }^{7}$ Sicilianos (2005), 484-490.
} 
Nations' and that might sooner or later extend also to the use of force. ${ }^{8}$ Several states in the Sixth Committee stressed that the regime of third-party countermeasures was in principle 'open to abuse' by powerful states, and that such measures were merely 'sanctions under another name'. ' Moreover, there was 'no imperative need' to create a parallel mechanism of enforcement to that already exercised by the Security Council under Chapter VII of the UN Charter. ${ }^{10}$

In short, by allowing a regime of third-party countermeasures as a matter of state responsibility law, 'under the banner of law, chaos and violence would come to reign among states, and international law would turn on and rend itself with the loftiest of intentions'. ${ }^{11}$ For these reasons and following the ILC's conclusion that state practice of third-party countermeasures was simply too obscure, the ILC found itself unable at the time of adoption to include a right to third-party countermeasures in the final version of ARSIWA, adopted on second reading in 2001. ${ }^{12}$ Instead, it opted for a rather ambiguously worded savings clause in Article 54 ARSIWA that neither endorsed nor precluded the right to third-party countermeasures in international law. ${ }^{13}$

The right to use third-party countermeasures was and remains one of the most controversial topics in the law of state responsibility. ${ }^{14}$ In legal doctrine, the concept of third-party countermeasures is understood to refer primarily to the use of countermeasures by one state against another in response to a breach of an international obligation owed to the international community as a whole (i.e. obligations erga omnes), ${ }^{15}$ and are taken in defence of some common interest of the international

\footnotetext{
${ }^{8}$ YbkILC (2001), Vol. I, 35, paras. 2 and 5 (Mr. Brownlie).

${ }^{9}$ See the statements made in the Sixth Committee by India (UN Doc. A/C.6/55/SR.15, 5-6), paras. 39, 31; and to the same effect; and those by China (UN Docs. A/CN.4/515, 69-70; A/C.6/56/SR.11, 10); Botswana (UN Doc. A/C.6/55/SR/15, 10, para. 63); Tanzania (UN Doc. A/C.6/55/SR.14, 9, paras. 4647); and Mexico UN Doc. A/CN4/515/Add.1, 9-10).

${ }^{10}$ See Mexico's statement (UN Doc. A/CN4/515/Add.1, 9-10), noting that that the response to such violations of international law was already defined by Chapter VII of the UN Charter, meaning it would be unacceptable to introduce a parallel enforcement mechanism.

${ }^{11}$ Weil (1983), 432-433.

${ }^{12}$ ILC, Draft Articles on the International Responsibility of States for Internationally Wrongful Acts (2001) [cit. ARSIWA]. See also Crawford, Fourth Report on State Responsibility (2001), paras. 70-74.

${ }^{13}$ ILC, Commentary to ARSIWA (2001), Article 54, paras. 6-7 [cit. ARSIWAC].

${ }^{14}$ See Gaja (2010), 957, 962; and Tams (2010), 390 and 397.

${ }^{15}$ Barcelona Traction, Light and Power Company, Limited, ICJ (1970) paras. 33-34 [cit. Barcelona Traction].
} 
community. ${ }^{16}$ State practice indicates that third-party countermeasures are an increasingly common phenomenon in contemporary international relations in response to breaches of norms expressing community interests, particularly in the fields of human rights and humanitarian law. ${ }^{17} \mathrm{~A}$ right to third-party countermeasures therefore appears to be emerging under customary international law. ${ }^{18}$ Alongside this development, the emphasis placed on collective interests in contemporary international law has led the Security Council to increasingly assert its own enforcement competences for breaches of community interests such as obligations erga omnes or peremptory norms of international law. ${ }^{19}$ In doing so, the Security Council has integrated breaches of international law into its determinations of a threat to the peace under Article 39 of the UN Charter, drawing on expansive interpretations of its mandate for the maintenance of international peace and security to provide a collective or institutionalised response to breaches of this nature. ${ }^{20}$ The possibility for overlapping enforcement competences has been illustrated also in practice, in which individual states have taken third-party countermeasures in the absence of effective enforcement by the Security Council. ${ }^{21}$ In 2012, following the lack of an effective response to the then unfolding situation in Syria, the US Secretary of State Clinton called for the states part of the Friends of Democratic Syria group to take measures against President Al-Assad, explaining that '[when f]aced with a neutered Security Council, we have to redouble our efforts outside of the United Nations with those allies and partners who support the Syrian people's right to have a better future'. ${ }^{22}$ Third-party countermeasures have also been taken concurrently with Security Council enforcement under Chapter VII of the UN Charter, most recently in response to the situation in Libya. ${ }^{23}$ Despite the possibility for overlapping enforcement competences at the individual and institutional levels, the legal

\footnotetext{
${ }^{16}$ Alland (2002), 1221-1223.

${ }^{17}$ See Chapter 3.3.

${ }^{18}$ Dawidowicz (2017), 282-284; Tams (2005), 249-251; Katselli Proukaki (2010), 201-209.

${ }^{19}$ Gowlland-Debbas (2001), 1-29; see also UNSCR 161 B on Congo; and UNSCR 418 (1977) on South

Africa, both of which took into account essentially internal situations involving violations of human rights and/or the right to self-determination.

${ }^{20}$ See UNGA Res. 60/1.

${ }^{21}$ Dawidowicz (2006), 417-418.

22 'Clinton Calls for "Friends of Democratic Syria" to Unite Against Bashar al-Assad', The Guardian (5 February 2012).

${ }^{23}$ See Chapter 4.3.3, below.
} 
position of third-party countermeasures in relation to the Security Council's enforcement competences remains uncertain. ${ }^{24}$

If both the law of state responsibility and the UN Charter system of collective security now provide for the legal consequences resulting from serious breaches of international law, then it is necessary to reconsider the arguments made in the ILC and by states in the Sixth Committee regarding the relationship between third-party countermeasures and the Security Council's enforcement powers under Chapter VII of the UN Charter. This relationship raises complex issues relating to the coexistence and coordination of two distinct bodies of law in response to breaches of obligations erga omnes (partes). Fundamentally, this is a question of whether the enforcement of norms and obligations expressing community interests should take place within a unilateral or institutional framework. ${ }^{25}$ The question is therefore closely related not only to the issue of ensuring the effective enforcement of common interests of the international community, but also more broadly to the need to preserve the coherence of the international legal order. ${ }^{26}$

\subsection{Purpose and Research Questions}

The purpose of this thesis is to investigate the relationship between the use of thirdparty countermeasures, taken by individual states under the law of state responsibility, and the Security Council's enforcement powers, under Chapter VII of the UN Charter. As was stated above, the relationship between the two raises a number of complex legal issues that relate to the need for a balance between the effective enforcement of community interests and the preservation of coherence in the international legal order.

For these purposes, this thesis will address the following research question:

Does the triggering of Security Council enforcement action under Chapter VII of the UN Charter (a) preclude the right of individual states to adopt third-party

\footnotetext{
${ }^{24}$ Dawidowicz (2017), 255-256; Gowlland-Debbas (2010), 122, 124; Sicilianos (2010), 1140-1142; Palchetti (2014) 1234-1236; Crawford (2013), 709; and HRC, Report by Special Rapporteur Jazairy (2015), 17-18.

${ }^{25}$ Gowlland-Debbas (2010), 126.

${ }^{26}$ ILC, Report on the Fragmentation of International Law (2006), paras. 481-483, 491-493.
} 
countermeasures, or (b) imply an obligation of individual states to end or modify thirdparty countermeasures already adopted in response to the same situation?

Each main body chapter of this thesis will aim to address a sub-question with the aim of clarifying the legal argumentation for the response to the main research question. These are the following:

- What is the role of the Security Council within the UN Charter framework for collective security in enforcing and protecting the shared values and interests of the international community? (Chapter 2)

- What is the status in international law of the right of states to take third-party countermeasures in response to a breach of community interests? (Chapter 3)

- What is the relationship between the use of third-party countermeasures under the law of state responsibility and Security Council enforcement measures in accordance with Chapter VII of the UN Charter? (Chapter 4)

\subsection{Delimitations}

The scope of this study is limited to aspects relevant to the relationship between thirdparty countermeasures and Security Council enforcement in response to breaches of obligations erga omnes. As a number of studies have already been devoted to the topic of determining the permissibility in international law of the use of third-party countermeasures, this study will not focus on an assessment of state practice to this end. The use of state practice in Chapters $3^{27}$ and $4^{28}$ has the more limited aim of presenting and systematising previous research to illustrate the relationship between third-party countermeasures and the Security Council's enforcement powers. This study is also limited to the use of third-party countermeasures in the situations envisaged under Article 48 ARSIWA, that is, responses to breaches of obligations erga omnes by a noninjured state within the meaning of Article 42 ARSIWA. While the concept of norms jus cogens has some overlap, in terms of the interests protected, with obligations erga omnes, the hierarchically superior nature of norms jus cogens is different to the matter

\footnotetext{
${ }^{27}$ See Chapter 3.3.

${ }^{28}$ See Chapter 4.3.
} 
of legal standing to enforce a breach of international law and is not directly relevant to the purpose and research questions of this study. Therefore, norms jus cogens will only be dealt with in their relationship to obligations erga omnes.

This thesis aims to study non-forcible measures in response to breaches of community interests, and accordingly the use of measures involving the use of force, whether in the form of countermeasures or Security Council enforcement, are excluded from its scope. Further, this study does not aim to place the use of third-party countermeasures within the context of the Responsibility to Protect, and as such references to this framework will only be made were relevant to the overall purpose of determining the legal position of such measures in relation to Security Council enforcement measures. Political or policy considerations, although key considerations in a state's decision to take countermeasures, are not considered at length. Also excluded from the scope of this thesis are the consequences of non-forcible measures, in particular the adverse human rights impact of such measures, as this does not impact the assessment of the law on either state responsibility or collective security.

\subsection{Methodology}

The method used for this thesis is the legal doctrinal method. ${ }^{29}$ The legal doctrinal method is concerned with the analysis of the sources of law in order to identify existing law. It is a method associated with positivist legal research, meaning that it considers the law as it is rather than examining its morality or the effectiveness. For the purposes of this thesis that is concerned with determining the legal position of third-party countermeasures in relation to the Security Council's enforcement powers this is a strength as it allows for the separation of the law in itself from its effects or application. However, in the context of international law, it also has some weaknesses, in particular that this method might not allow for the taking into account of certain extra-legal interests that may influence state behaviour.

\footnotetext{
${ }^{29}$ Hutchinson (2015), 130-138.
} 
This thesis has studied the sources of international law to determine the lex lata of the use of third-party countermeasures in relation to the Security Council's enforcement powers under Chapter VII of the UN Charter. As such, this study has focused on an analysis of international treaties, custom and general principles of law, with international case law as a subsidiary means for the determination of the rules of law, in accordance with Article 38 of the Statute of the ICJ. ${ }^{30}$ The main frameworks analysed are the UN Charter, regarding the system of collective security, and the rules of customary international law governing countermeasures as a matter of state responsibility.

In order to interpret the sources of international law, legal doctrine is used to clarify the meaning of the law. This thesis has also taken into account arguments relating to the coherence of the international legal order, primarily those raised in the ILC's 2006 report on the fragmentation of international law. ${ }^{31}$ The starting-point of this thesis is therefore that the international legal order forms a coherent system and should be systematised to this end.

This thesis also considers instances of state practice with the aim of illustrating the international law governing the use of countermeasures and to highlight any discrepancies between theory and practice regarding the use of third-party countermeasures. It must be restated that this study does not aim to prove or disprove the existence of elements of opinio juris, and the discussion of state practice must be read in the light of this important limitation of scope. A few methodological challenges of the assessment of state practice must be addressed. The practice of third-party countermeasures is generally obscure, as states rarely offer precise legal justification for their actions. In some cases, states provide the rationale for the measures taken in the trigger statement preceding the response. The lack of clarity in state practice means that previous studies of state practice must therefore be read critically, taking into account the possibility of misinterpretation.

\footnotetext{
${ }^{30} \mathrm{UN}$, Charter of the United Nations and the Statute of the International Court of Justice, 24 October 1945, 1 UNTS XVI, Article 38.

${ }^{31}$ ILC, Report on the Fragmentation of International Law (2006), paras. 481-483, 491-493.
} 
The choice of the legal doctrinal method is motivated for two reasons. The first reason is that the legal position of the right to third-party countermeasures and the role of such measures in the context of enforcing of norms or obligations expressing community interests are currently unclear and in need of further clarification. Secondly, the legal debate on the use of countermeasures in the broader context of the enforcement of obligations erga omnes is controversial with arguments often closer to politics than law. Therefore, it is necessary to separate law from politics to order to provide an answer regarding the law to the question about the relationship between third-party countermeasures and Security Council's enforcement powers. The extra-legal considerations of this relationship are briefly considered within the context of the case studies, which are used to highlight and problematize the results of the legal doctrinal method in determining the status of the law in other sections of the thesis.

\subsection{Materials and Previous Research}

The materials used for this thesis are relevant treaties as well as the texts codifying customary international law, primarily the relevant provisions of the UN Charter and ARSIWA. The commentaries to these documents are used as interpretative tools. As this thesis studies the Security Council's enforcement measures, notice has also been taken of the derivative obligations of the UN Charter, specifically the legally binding decisions of the Security Council. A number of secondary sources have been consulted to clarify the meaning of countermeasures under general international law. ${ }^{32}$

The research on third-party countermeasures is limited in number but generally of a comprehensive nature. Previous research has focused primarily on the assessment of the permissibility or legality of third-party countermeasures under general international law and the identification of elements of opinio juris. ${ }^{33}$ There is currently little research on the nature of the relationship between third-party countermeasures and Security Council enforcement measures, despite significant attention accorded the topic in debates during

\footnotetext{
${ }^{32}$ On non-forcible countermeasures, see Zoller (1984); Elagab (1988); and Sicilianos (1990).

${ }^{33}$ On state practice of third-party countermeasures, see Tams (2005), 207-251; Dawidowicz (2006), 350407; Katselli Proukaki (2010), 90-209; and Dawidowicz (2017), 111-238.
} 
the ILC's codification of the law of state responsibility. ${ }^{34}$ The commentaries on this relationship are brief and rarely offer complete legal justification, which warrants further study of this topic. ${ }^{35}$ The limited amount of previous research is possibly because attention has for obvious reasons focused on the permissibility of third-party countermeasures. If the right to third-party countermeasures is emerging under customary international law, then it is crucial to consider the implications of such a right in relation to international institutions such as the Security Council.

\subsection{Structure}

Following the introduction, there are three main chapters and then a final chapter with some concluding remarks.

Chapter 2 deals with what can be described as the collective dimension of international law. It introduces the concept of community interests and considers the role of the Security Council for the protection and enforcement of such interests. This collective dimension is crucial to understanding the legal interests of third states in enforcing obligations erga omnes, explaining why individual states may have a legal interest in enforcing obligations of this nature.

Chapter 3 considers the use of third-party countermeasures by individual states in response to breaches of obligations erga omnes. Countermeasures can be tentatively described as unilateral coercive measures taken by one state against another in response to a breach of international law, with view of ensuring the return to legality. The chapter is split into two parts. The first part considers the theoretical framework applicable to countermeasures as well as third-party countermeasures, and the second part considers state practice to illustrate the discrepancy between theory and practice.

Chapter 4 analyses the relationship between the use of third-party countermeasures and Security Council enforcement measures. This chapter is split into two parts, similar to those of Chapter 3. The first part considers the theoretical framework of the relationship

\footnotetext{
${ }^{34}$ Cf. Gowlland-Debbas (2010) 115-138.

${ }^{35}$ See Dawidowicz (2017), 255-262; Tams (2005), 264-268; and Calamita (2009), 1437-1441.
} 
between third-party countermeasures and the Security Council's enforcement powers. The second part examines two case studies in which third-party countermeasures were taken concurrently with Security Council enforcement measures under Chapter VII of the UN Charter.

Finally, Chapter 5 offers some concluding remarks.

\section{Community Interests in International Law}

\subsection{Introduction}

The emergence of community interests that are shared among states in the international community reflects the progressive development of international law from a system consisting of the 'minimal law' ${ }^{36}$ necessary to enable the peaceful coexistence of states, to a legal order based on cooperation that promotes the shared interests of the international community. ${ }^{37}$ The emergence of an international community of states as a concept of international relations changed the international legal balance in such a way so that a state, which violated fundamental principles of international law, would now be faced with the international community as a whole. ${ }^{38}$ Within the limits of its mandate under Article 24 of the UN Charter for the maintenance of international peace and security, the Security Council has assumed an active role in enforcing obligations established for the protection of a collective interest, drawing on increasingly expansive interpretations of the notion of a threat to the peace to protect such interests. ${ }^{39}$ In particular, the Security Council has increasingly taken measures in response to serious breaches of human rights and humanitarian law, integrating human rights designation criteria into its resolutions. ${ }^{40}$ These activities can be described as a form of centralised or collective response to serious breaches of international law. ${ }^{41}$

\footnotetext{
${ }^{36}$ Allot (1990), 324.

${ }^{37}$ Villalpando (2010), 391; referencing Friedmann (1964), 60-62 and 367.

${ }^{38}$ Greig (2002), 563-566.

${ }^{39}$ Gowlland-Debbas (2001), 1-29.

${ }^{40}$ Ugarte and Genser (2014), 14-21.

${ }^{41}$ Gowlland-Debbas (2010), 116 and 126-128.
} 
This chapter will provide a background to the concept of community interests in international law and the role of international institutions in protecting such interests. First, it considers the emergence of community interests as a concept of international law and their doctrinal expressions. Second, it considers the role of international institutions in protecting and enforcing community interests, with emphasis on the UN Charter and the enforcement mandate of the Security Council under Chapter VII of the UN Charter.

\subsection{Community Interests in International Law}

\subsubsection{The Emergence of Community Interests}

Community interests refer to the values or interests that are of common concern to all states or a group of states within the international community. Community interests may be further defined as '[a] consensus according to which respect for certain fundamental values is not to be left to the free disposition of states individually inter se, but is recognised and sanctioned by international law as a matter of concern to all States' ${ }^{42}$ Interests of this nature are found in a number of areas, not least in the areas of international peace and security, solidarity between developed and developing countries, protection of the environment and the concept of a 'common heritage of mankind', and in the international concern for the protection of human rights. ${ }^{43}$ The emergence of community interests in international law reflects the intensification of international relations and the need for increased cooperation between states to protect their shared values or interests. ${ }^{44}$ This builds on a conceptualisation of international law as serving not only the interests of individual states, but also the common interests of states and the international community. ${ }^{45}$

\footnotetext{
${ }^{42}$ Simma (1994), 233-235. See also Jessup (1948), 2.

${ }^{43}$ Simma (1994), 236-243.

${ }^{44}$ Benvenisti and Nolte (2018), 4.

${ }^{45}$ Gabcikovo-Nagymaros Project (Hungary/Slovakia), ICJ (1997), 7, Separate Opinion of Judge Weeramantry, $88-119$, at 115 , considering that ' $[\mathrm{w}] \mathrm{e}$ have entered an era in which international law subserves not only the interests of individual states, but looks beyond them and their parochial concerns to the greater interests of humanity and planetary welfare'.
} 
Traditionally, international law had the more limited function of delimiting the respective spheres of sovereignty of states on the basis of the principles of state sovereignty and non-intervention. ${ }^{46}$ Relations between states were traditionally limited without significant instances of cooperation. In this context, international law served mostly to resolve conflicts in the exercise of territorial jurisdiction. ${ }^{47}$ International norms therefore centred on the preservation of each state's sovereign rights rather than the achievement of shared values or objectives. ${ }^{48}$ As such, the legal relationships were bilateral in nature and built on the principle of reciprocity, existing between pairs of states only. ${ }^{49}$ The increase in inter-state relations led to more structured cooperation between states and to a new category of collective interests that could not be fulfilled by traditional means. ${ }^{50}$ Interests of this nature included protection of common goods or values, such as international peace and security, humanity, or the environment, the attack on which by one state would be damaging to all other members of the international community, the protection of which could not be secured in a fragmented way. ${ }^{51}$ In international legal theory, the concept of community interests has been used to refer to extra-legal values that go beyond the sovereignty of individual states, conceptualising community interests as part of the development in the direction of a multilateral public order on a shared or common basis. ${ }^{52}$

The recognition of certain community interests in the normative content and structure of contemporary international law is now established feature in international law. ${ }^{53}$ The legal expression of community interests can be found in the concept of communitarian norms (or community interest norms), which can be described as legal norms established in the collective interest and that are binding either on all states or on a group of states. ${ }^{54}$ An early example is the Genocide Convention, adopted in 1948, which lays down an obligation on states to take steps for the prevention and punishment of

\footnotetext{
${ }^{46}$ Cassese (2005), 13-15.

${ }^{47}$ Villalpando (2010), 390.

${ }^{48}$ Island of Las Palmas (Netherlands, US), arbitral award (1982), 838.

${ }^{49}$ Cassese (2005), 13-15.

${ }^{50}$ Villalpando (2010), 390-394.

${ }^{51}$ Simma (1994) 235-236; and Villalpando (2010) 391-392.

${ }^{52}$ For an overview, see Feichtner, 'Community Interest', MPEPIL, paras. 7-12.

${ }^{53}$ Besson (2018), 36. See further Simma,(1994); and Gaja (2013).

${ }^{54}$ Cassese (2005), 15-17; and Villalpando (2010), 390-392.
} 
genocide. ${ }^{55}$ In its Advisory Opinion Reservations to the Convention on Genocide, the ICJ clarified that under legal regimes of this nature 'States do not have any interests of their own; they merely have, one and all, a common interest, namely, the accomplishment of those high purposes which are the raison d'etre of the [Genocide Convention]'. ${ }^{56}$ Obligations in the Genocide Convention could not be reduced into meaningful reciprocal legal relationships, as the obligations to prevent and punish genocide are not owed in relation to any state but to the community of states and established in the collective interest. ${ }^{57}$ Therefore, the protection of community interests through legal norms marks the departure from the traditional legal order based on bilateralism and the principle of reciprocity, to an international legal order that promotes certain higher interests shared by all states of the international community. ${ }^{58}$

While contemporary international law has in some respects moved beyond exclusively bilateral legal relationships, these bilateral structures still constitute the basis on which new developments are taking place. ${ }^{59}$ International legal obligations continue to exist in principle between individual states in a 'bilateral minded' ${ }^{60}$ international legal system, one in which state sovereignty and non-intervention continue to be fundamental principles. In the majority of legal relationships, therefore, only the state that is the carrier of the right in the bilateral sense is entitled to the full range of legal redress in the event of a breach of the obligation in question. ${ }^{61}$ As such bilateralism protects individual states from unlawful interference, but leaves the enforcement of a breach to the state whose subjective rights have been infringed. ${ }^{62}$

\footnotetext{
${ }^{55}$ Convention on the Prevention and Punishment of the Crime of Genocide (1948).

${ }^{56}$ Reservations to the Convention on Genocide, ICJ (1951), 23.

${ }^{57}$ YbkILC (1958), Vol. II, 44, para. 91; ILC, Report on the Fragmentation of International Law (2006), para. 385. See also the S.S Wimbledon (UK et al. v. Germany), PCIJ (1923), in which the PCIJ accorded legal standing to states not directly affected by a breach but that had a legal interest in ensuring compliance with the international regime of the freedom of navigation, an early expression of nonreciprocal legal relationships.

${ }^{58}$ Katselli Proukaki (2010), 11, 16-17.

${ }^{59}$ Simma (1994), 229-230.

${ }^{60}$ Riphagen, Third Report on State Responsibility (1982) para. 91, 97-8.

${ }^{61}$ Reparation for injuries suffered in the service of the United Nations, ICJ (1949), 181-182.

${ }^{62}$ See, for example, Cassese (2005), 13-15.
} 


\subsubsection{Obligations Erga Omnes and Norms Jus Cogens}

International law has developed concepts that are doctrinal expressions of community interests, including the concepts of peremptory norms of international law (norms jus cogens) and of obligations owed to the international community (obligations erga omnes or erga omnes partes). ${ }^{63}$ Peremptory norms of international law were first recognised at the adoption of VCLT in 1969, as legal norms 'accepted and recognised by the international community of States as a whole' and 'from which no derogation is permitted', overriding conflicting norms of international law. ${ }^{64}$ The reference to the 'international community' reveals the shift in international law towards recognising certain higher interests in the name of the international community and the development of an international public order. ${ }^{65}$ The concept of obligations erga omnes appeared a year later in the 1970 Barcelona Traction case, ${ }^{66}$ and has certain similarities with the concept of peremptory norms of international law. ${ }^{67}$ In a now famous obiter dictum, ${ }^{68}$ the ICJ drew an essential distinction between obligations arising between states on a bilateral and reciprocal basis, and 'obligations of a State towards the international community as a whole' which are 'the concern of all States' and for whose protection all states can be held to have a legal interest. ${ }^{69}$ The concept of obligations erga omnes refers to the group of states to which an obligation is owed, and therefore does not reflect hierarchical superiority in relation to conflicting obligations. ${ }^{70}$ Although the concepts of obligations erga omnes and norms jus cogens have different legal consequences, they are related to one another in terms of that they both protect interests of a collective nature. A rule from which no derogation is permitted is normally also of such a fundamental nature that all states can be held to have a legal interest in its performance, meaning that there may be overlap between the two. The obligations exemplified in the Barcelona Traction dictum as erga omnes include norms of a peremptory character and illustrate the relationship between the two, including 'the outlawing of acts of aggression and of genocide, as also from the principles and rules

\footnotetext{
${ }^{63}$ Simma (1994), 285-286.

${ }^{64} \mathrm{UN}$, Vienna Convention on the Law of Treaties (1969), Article 53.

${ }^{65}$ Orakhelashvili (2006), 27-28.

${ }^{66}$ Barcelona Traction, paras. 33-34. For further analysis of this case, see Ragazzi (1997), 8-12.

${ }^{67}$ See, for example, Kadelblach, (2006), 26-28.

${ }^{68}$ On the significance of the obiter dictum character of the statement, Tams (2005), 167-173.

${ }^{69}$ Barcelona Traction, paras. 33-34.

${ }^{70}$ See Gaja (1989), 151-160.
} 
governing the basic rights of the human person, including protection from slavery and racial discrimination' ${ }^{71}$

The legal significance of the Barcelona Traction dictum lies in the distinction between different types of legal obligations, namely those owed in bilateral legal relationships and those that are of concern to a community of states. ${ }^{72}$ The passage has been described as 'a great leap forward ${ }^{73}$ in the development of a common core of norms for the protection of communal values and interests beyond the traditional bilateral structures of international law. ${ }^{74}$ However, the ICJ has so far remained silent on the enforcement of obligations erga omnes. ${ }^{75}$

\subsubsection{International Crimes in Draft Article 19 [1996]}

In brief, community interests had a significant influence on the ILC's codification of the law of state responsibility. ${ }^{76}$ This was reflected particularly in the differentiated regimes of state responsibility on the basis of the importance of the obligation breached, which aimed to operationalize the regimes of norms jus cogens and obligations erga omnes. Draft Article 19 [1996] drew a distinction between international crimes and international delicts. ${ }^{77}$ The concept of international crimes, or state crimes, essentially consisted of breaches of norms jus cogens, including norms relating to the maintenance of international peace and security, self-determination, obligations safeguarding the human being such as those prohibiting slavery, genocide and apartheid as well as obligations to preserve the human environment. ${ }^{78}$ The differentiated regime of responsibility for international crimes and international delicts was eventually dropped and was replaced by a single regime of state responsibility for all types of international legal obligations. Instead, Article 48 ARSIWA in the current draft provides that states not directly injured by a breach of an international obligation may have a legal interest

\footnotetext{
${ }^{71}$ Barcelona Traction, para. 34.

${ }^{72}$ Ragazzi, (1997), 17.

${ }^{73}$ Simma (1994), 293.

${ }^{74}$ Tams (2005), 2-3; see also East Timor, ICJ (1995), para. 29; and Legal Consequences of the Construction of a Wall in the Occupied Palestinian Territory, ICJ (2004) 155-160.

${ }^{75} \mathrm{Cf}$. IDI, Resolution Obligations and Rights Erga Omnes in International Law (2005).

${ }^{76}$ See Chapter 3.2, below.

${ }^{77}$ ILC, Report of the Drafting Committee: State Responsibility - Draft Articles Provisionally Adopted by the Drafting Committee on Second Reading (1996), draft Article 19 [1996].

${ }^{78}$ See further Gaja (1989), 151-160.
} 
in the compliance of other states with obligations erga omnes and erga omnes partes by virtue of their membership in the international community, allowing those states limited rights of invocation. ${ }^{79}$ The drafting process of the law of state responsibility is considered in further below. ${ }^{80}$

\subsection{Community Interests and the UN Charter}

\subsubsection{The UN Charter as the Constitution of the International Community}

The emergence of community interests in international law has led to institutionalisation, or organisation, of the international community. ${ }^{81}$ This process builds on the notion of an international community of states, denoting 'an overarching system which embodies a common interest of all States and, indirectly, of mankind' ${ }^{82}$ International institutions have had an increasingly important role in formulating and ensuring the compliance of states with existing communitarian norms, but also in allowing for cooperation between states in the area of community interests, creating some form of international solidarity. ${ }^{83}$

The UN Charter is considered to have translated the concept of international community from an abstract and mostly ideological notion 'to something approaching institutional reality ${ }^{84}$ In particular, the UN Charter provides for a highly institutionalised approach to the notion of community interests, not only with regard to responses to illegal uses of force but also community interests within a larger scope. ${ }^{85}$ The Charter not only provides for a framework for the maintenance of international peace and security, but also an overarching network of organisations to deal with a large number of community interests in the economic, social, ecological or humanitarian fields. Outside the framework of the UN Charter, a number of regional organisations as well as

\footnotetext{
${ }^{79}$ ARSIWAC (2001), Article 48, paras. 1-2.

${ }^{80}$ See Chapter 3.2, below.

81 Simma (1994), 235.

82 Tomuschat (1993), 227.

${ }^{83}$ Simma (1994), 283-284; Weil (1983) 433; and Macdonald (1993), 293.

${ }^{84}$ Simma (1994) 258.

85 Ibid., 257.
} 
international institutions have emerged. ${ }^{86}$ In this fragmented view of international institutions protecting common interests of the international community, there are few means for the direct enforcement of norms established in the collective interest, meaning that international institutions remain deficient with respect to the realisation and protection of community interests. ${ }^{87}$

There are several features of the UN Charter that make it similar to that of a constitution of the international community. The UN Charter offers not only a codification of ground rules for the activities of the organisation, but also the principles that govern the overall political system of the international legal order, such as the principles of sovereign equality, the prohibition of the threat or the use of force, good faith and the principle of the intangibility of the domaine réservé of the organisation. The UN Charter also provides a form of division of powers between its principal organs. ${ }^{88}$ The powers of the Security Council in particular depart from the traditional consent-based ground rules of the international legal order, with its authority to adopt decisions that are legally binding not only on member states, but also by interpretation on non-member states. ${ }^{89}$ While the view of the UN Charter as the 'constitution' of the international community is gaining traction in an international legal order increasingly concerned with community interests, the idea has traditionally been treated with great caution. ${ }^{90}$ The main reasons for this are related to the unequal distribution of power between competing and (at least formally) equal sovereign states and their different levels of influence both in the creation of the UN Charter and in its operation, which is in principle an issue of the legitimacy of the UN Charter as a constitutional document for the international community as a whole. ${ }^{91}$ The UN Charter is perhaps best understood as having introduced a 'radical change' in the structure of international law by introducing a set of legal principles that have been interpreted by its principal organs with the text as reference, creating a link between the protection of essential interests and obligations. ${ }^{92}$ As such, the constitutional characteristics of the UN Charter are perhaps best

\footnotetext{
${ }^{86}$ Ibid., 283-284.

${ }^{87}$ Ibid., 285-286.

${ }^{88}$ Ibid., 258-261. See further MacDonald (1987); 199, 128; Macdonald (1988), 196.

${ }^{89}$ Tomuschat (1993), 256; and Dupuy (1993), 617.

${ }^{90}$ Simma (1994), 259-260.

${ }^{91}$ Dupuy (1997), 2-4.

${ }^{92}$ Ibid., 30-33. See also Kirchner (2004), 47, 51.
} 
understood as a rhetorical or ideological tool to promote the unity and coherence of the international legal order for the protection of shared values and interests of the international community.

\subsubsection{The Security Council under Chapter VII of the UN Charter}

The Security Council, with its wide-ranging powers as primarily responsible for the maintenance of international peace and security, has in some respects assumed a role as guarantor of community interests with increasingly expansive interpretations of its mandate. ${ }^{93}$ Under Article 24 of the UN Charter, the Security Council has the primary responsibility for the maintenance of international peace and security, with associated enforcement powers under Chapter VII of the UN Charter. ${ }^{94}$ The mandate can be described as the operational version of the UN's primary purpose of maintaining international peace and security as defined by Article 1(1) of the UN Charter, which serves to further illustrate the Security Council's central role under the UN Charter. ${ }^{95}$ In order to carry out its functions, the Security Council is competent to take enforcement measures under Chapter VII. ${ }^{96}$ Once the Security Council has determined the existence of a threat to the peace, breach of the peace, or an act of aggression under Article 39 of the UN Charter, it is competent to take the measures necessary to maintain or restore international peace and security under Articles 40-42 of the UN Charter. ${ }^{97}$ The decisions of the Security Council are legally binding nature by virtue of Article 25 of the UN Charter. ${ }^{98}$ In case of conflicting obligations, Security Council decisions have priority

\footnotetext{
93 Tomuschat (1993), 256; and Dupuy (1993), 617, considering that 'on a parfois l'impression qu'il [i.e. the Security Council] prétend agir telle une sorte d'organe exécutive de la communauté internationale...'. See also Frowein (1994), 355; Simma (1994), 261-262.

${ }^{94}$ This competence is primary, but not necessarily exclusive, as affirmed by the ICJ in the Legal Consequences of the Construction of a Wall, ICJ (2004), para. 26. The UNGA may be required to take steps for the maintenance of international peace and security under Article 11 of the UN Charter if the Security Council is prevented from acting or has been ineffective in the discharge of its duties. See UNGA Res. 377(V) and Simma (2012), Commentary to Article 24, paras. 17-18 and 19-31.

${ }^{95}$ Simma (2012), Commentary to Article 24, para. 33.

${ }^{96}$ UN Charter, Chapter VII, 'Action with Respect to Threats to the Peace, Breaches of the Peace, and Acts of Aggression'.

${ }^{97}$ Article 39 of the UN Charter: '[t]he Security Council shall determine the existence of any threat to the peace, breach of the peace, or act of aggression and shall make recommendations, or decide what measures shall be taken in accordance with Articles 41 and 42, to maintain or restore international peace and security'.

${ }_{98}$ Article 25 of the UN Charter: '[t]he Members of the United Nations agree to accept and carry out the decisions of the Security Council in accordance with the present Charter'.
} 
over other obligations of international law in accordance with Article 103 of the UN Charter. ${ }^{99}$

The Security Council was given deliberately wide discretionary powers to determine what constitutes a breach of or threat to the peace (or, an act of aggression) under Article 39 of the UN Charter, as well as in choosing how to respond in accordance with Articles 40-42. ${ }^{100}$ As such, the Security Council may be competent to respond to breaches of obligations erga omnes (or other communitarian norms) where they fall within the scope of Article 39 of the UN Charter. ${ }^{101}$ The mandate of the Security Council is in principle limited to interstate situations that involve a breach or a threat to international peace and security. ${ }^{102}$ However, the practice of the Security Council indicates that it has increasingly responded also to what are essentially internal situations within the member states, which fall outside the traditional scope of the Security Council's powers. ${ }^{103}$ This development can be traced back to the resolution on South Rhodesia in 1966, which considered that the systematic violations of human rights and fundamental freedoms and the absence of the rule of law in the country constituted a threat to international peace and security. ${ }^{104}$ Following the end of the Cold War, the Security Council was able to increase its activities under Chapter VII of the UN Charter and broaden its interpretation of the notion of a threat to the peace under Article 39 of the UN Charter. ${ }^{105}$ In a 1991 on Iraq, the Security Council stated that the human rights abuses and repression committed against parts of the civilian population in Iraq would '[lead] to threats against international peace and security', despite being a clearly internal situation. ${ }^{106}$ A year later, in the Summit Declaration of 31 January 1992 , the Security Council explicitly recognised that ' $[\mathrm{t}]$ he absence of war and military

\footnotetext{
${ }^{99}$ Questions of Interpretation and Application of the 1971 Montréal Convention arising from the Aerial Incident at Lockerbie (Libyan Arab Jamahiriya v. United States), ICJ (1998), 126 [cit. Lockerbie], in which the ICJ considered that obligations arising under Security Council resolutions adopted under Chapter VII of the UN Charter had priority over those of the Montréal Convention, see 15, 126. See also Tomuschat (1993) $252 \mathrm{ff}$.

${ }^{100}$ Gowlland-Debbas (2001b), 287. Generally, on the wide discretionary powers of the Security Council, see also Higgins (1963), 266; and Kelsen (1950), 727.

${ }^{101}$ De Hoogh (1996), 114-125.

102 Simma (2012), Commentary to Article 24.

${ }^{103}$ Tsagourias and White (2013), 45-48, 96-98; Gowlland-Debbas (1990), 288.

${ }^{104}$ Gowlland-Debbas (2001a), 1-29. See UNSCR 418 (1977), on South Africa; and UNSCR 161 B

(1961), on Congo, taking into account internal situations involving violations of human rights and/or the right to self-determination.

${ }^{105}$ Frowein (2001), 253.

106 Tsagourias and White (2013), 43; Gowlland-Debbas (2001b), 288-291.
} 
conflicts amongst States does not itself ensure international peace and security. The non-military sources of instability in the economic, social, humanitarian and ecological fields have become threats to peace and security'. ${ }^{107}$ Further, in 2005, the General Assembly adopted at the World Summit the Responsibility to Protect framework, considering that individual states as well as the international community had a special responsibility to protect civilian populations. ${ }^{108}$ The Security Council reaffirmed these principles in Resolution 1674 (2006) on its responsibility to protect civilians in armed conflict from acts of ethnic cleansing, genocide, crimes against humanity, and war crimes in armed conflict. ${ }^{109}$

Other examples of the Security Council's broadened conception of a threat to the peace include resolutions with reference to human rights violations taking place in the context of civil wars, or violations of the right to self-determination, for example in Somalia, Liberia, Georgia, Angola, Rwanda, the Former Republic of Yugoslavia and Haiti. ${ }^{110}$ In response to these situations, the Security Council imposed sanctions based on a finding of a threat to international peace and security, as well as a finding of a breach of international law, although not formally required to do so in accordance with its mandate. ${ }^{111}$ The violation of a norm or obligation expressing a community interest has not in any of these cases constituted the sole basis for Security Council action, but has formed an integrated part in the determination of a threat to the peace under Article 39 of the UN Charter. ${ }^{112}$ This reflects the modern conceptualisation of international peace and security, which includes ethnic cleansing, genocide and other gross violations of human rights, and grave breaches of international humanitarian law, as component parts of the Security Council's peace maintenance function. ${ }^{113}$

\footnotetext{
${ }^{107}$ UNGA Res. 60/1.

${ }^{108}$ Ibid. See also UNGA Res. 63/308.

${ }^{109}$ UNSCR 1674; and UNSCR 1973.

${ }^{110}$ UNSCR 733 (1992), on Somalia; UNSCR 757 (1991), on Bosnia and Herzegovina (the Former Republic of Yugoslavia); UNSCR 788 (1992) on Liberia; UNSCR 841 (1993) on Haiti; UNSCR 858 (1993) on Georgia; UNSCR 864 (1993) on Angola; and UNSCR 918 (1994) on Rwanda. The resolutions on Somalia and Rwanda are both based on human rights concerns, with the Security Council notably failing to take effective enforcement action to prevent the genocide in Rwanda in 1994, see Von Geusau (1999), 6-9.

${ }^{111}$ Gowlland-Debbas (2010), 128; see also Gowlland-Debbas (1990), 288.

${ }^{112}$ De Hoogh (1996), 119-122; Von Geusau (1999), 6-9.

${ }^{113}$ Gowlland-Debbas (2001a), 1-29.
} 
The expanding mandate of the Security Council to include what are essentially internal situations illustrates the shift in contemporary international law in the direction of increasingly recognising community interests as integral parts of the international security fabric. ${ }^{114}$ In this regard, Security Council sanctions have had the function as a form of collective response to violations of norms expressing community interests, institutionalising the enforcement of breaches of this nature. ${ }^{115}$ The mandate of the Security Council must, however, be understood in the rather limited terms of the Security Council's capacity as a political organ. The Security Council is not intended to function as a judicial organ or to make judicial determinations of situations. ${ }^{116}$ While this permits the Security Council to take into account extra-legal considerations and in some cases act preventatively within its mandate for international peace and security, it also means that the Security Council's competences will not necessarily correspond to all breaches of international law, regardless the seriousness of the breach. This is the case in particular where such breaches are not clearly linked to threats to or to breaches of international peace and security. ${ }^{117}$ This point has been clearly illustrated in the failure of the Security Council to act in response to several major international crises, including most recently the massive violations of human rights and humanitarian law in Syria from 2011, or the alleged acts of genocide, war crimes and crimes against humanity committed in Myanmar in 2017-2018. ${ }^{118}$ In this context, it has been observed that 'leaving it up to the "organised international community", i.e. the United Nations, to react to breaches of obligations erga omnes border[s] on cynicism'. ${ }^{119}$

\subsection{Conclusion}

International law has witnessed the progressive development from a limited system of law concerned with the delimitation of state sovereignty to an international legal order based on cooperation and that gives prevalence to certain higher interests that are shared by members of the international community. This is evidenced in part by the emergence

\footnotetext{
${ }^{114}$ Gowlland-Debbas (2001b), 300-301.

${ }^{115}$ Boisson de Chazournes (1996), 149-173.

${ }^{116}$ See Perrin De Brichambaut (2010), 269-270, describing the Security Council as 'a political organ that produces resolutions having legal consequences'.

${ }^{117}$ Dawidowicz (2006), 335; and Sicilianos (1990), 136.

${ }^{118}$ Cf. Simma (1994) 246-248, 264-268 and 268-278.

119 YbkILC (2001), Vol. I, 305, para. 31 (Mr. Simma).
} 
of international legal norms established for the protection of collective interests, such as the 1948 Genocide Convention, but also by their doctrinal expression in the form of norms jus cogens in Article 53 of the 1969 VCLT and obligations erga omnes in the 1970 Barcelona Traction case. Norms jus cogens and obligations erga omnes are similar in their subject matter as both protect community interests, although with quite different legal consequences. The emergence and relatively quick acceptance of new categories of norms and legal obligations established in the collective interest demonstrates not only a rising social awareness among states, but also the recognition that the effective protection of community interests requires cooperation between states through institutional means. The most prominent example in this regard is the UN Charter, with a number of distinct features that make it similar to that of a constitution of the international community, including the codification of core principles governing international relations (i.e. the principles of sovereign equality, the prohibition of the threat or use of force, good faith, and the intangibility of the domaine réservé). The view of the UN Charter as a constitutional document for the international community appears to be based on the need for coherence and constitutionalisation of the international legal to protect certain collective interests.

The Security Council occupies a central role in the UN Charter as primarily responsible for the maintenance of international peace and security, with special enforcement powers under Chapter VII of the UN Charter. It has exercised its enforcement capabilities on the basis of increasingly expansive interpretations of the notion of a threat to the peace under Article 39 of the UN Charter. Serious violations of international law (typically violations of human rights and humanitarian law) have increasingly formed integral parts of the Security Council's decisions to take enforcement measures in accordance with Chapter VII of the UN Charter, even in response to internal situations. In this regard, Security Council responses can be understood as a form of collective response to violations of norms or obligations expressing community interests. However, the Security Council's political mandate means that its competences do not necessarily cover all breaches of such norms. This has been illustrated with particular poignancy in the lack of efficient response to some major international crises, most recently the massive violations of human rights and humanitarian law committed in Syria and Myanmar, for example. If effective 
enforcement of norms and obligations expressing community interests is the main objective, then it is problematic to consider Security Council enforcement measures as a form of collective response to community interests, however central of a role the Security Council currently occupies in this area.

\section{Third-Party Countermeasures in International}

\section{Law}

\subsection{Introduction}

Third-party countermeasures refer to the use of countermeasures by a state other than the injured state in response to a breach of a communitarian norm. ${ }^{120}$ In the absence of a settled terminology, there is a wide variety of terms in legal doctrine to describe this legal category, including collective countermeasures, ${ }^{121}$ third-State countermeasures, ${ }^{122}$ countermeasures of general interest, ${ }^{123}$ countermeasures omnium, ${ }^{124}$ solidarity measures, ${ }^{125}$ as well as multilateral sanctions. ${ }^{126}$ The common denominator for the use of these terms is that they envisage the use of third-party countermeasures as a response to breaches of communitarian norms taken by states acting in their individual capacity and in defence of a collective interest. ${ }^{127}$ Third-party countermeasures have been conceptualised as a means to operationalize multilateral obligations such as obligations erga omnes or erga omnes partes, ${ }^{128}$ allowing states to respond to breaches of such obligations 'in between war and words'. ${ }^{129}$ This is significant because the ICJ in recognising obligations erga omnes and erga omnes partes, in the 1970 Barcelona Traction case, did not offer clarification on the means for the enforcement of such

\footnotetext{
${ }^{120}$ ARSIWAC (2001), Article 54, para. 1; Dawidowicz (2017), 31-34.

${ }^{121}$ Crawford (2013), 703.

${ }^{122}$ Charney (1989), 75; Katselli Proukaki (2010), 2-3; Bird (2011), 899; Hakimi (2014), 119.

123 Alland (2002), 1221; Tams (2005), 199, 242.

${ }^{124}$ Villalpando (2005), 366.

125 Koskenniemi (2001), 337.

${ }^{126}$ YbkILC (2000), Vol. I, 311, para. 81 (Mr. Brownlie), 312, para. 11 (Mr. Momtaz).

${ }^{127}$ See Dawidowicz (2017), 31-34.

${ }^{128}$ Gaja (2013), 130.

${ }^{129}$ UNGA, Report of the Secretary-General, In Larger Freedom: Towards Development, Security and Human Rights for All (2005), 30, para. 109.
} 
obligations and has yet to pronounce itself on this matter. ${ }^{130}$ It may also be recalled from Chapter 2 that the Security Council, although increasingly occupied with the enforcement of community interests, has a limited political mandate. ${ }^{131}$ The legal interest of third states in the compliance of other states with obligations erga omnes is recognised in Article 48 ARSIWA, according to which third states limited rights of invocation by virtue of their membership the international community. ${ }^{132}$ However, third states do not have a clearly recognised right to take third-party countermeasures in the situations envisaged under Article 48 ARSIWA, given the inconclusive position of the savings clause in Article 54 ARSIWA. ${ }^{133}$

This chapter will provide an overview of the legal framework governing countermeasures and the position in international law of third-party countermeasures. This is followed by a systematisation of state practice in this area into two broad categories that concern violations of human rights and humanitarian law and illegal uses of force. Finally, the legal conditions and procedural safeguards on the use of countermeasures are briefly considered as they are applicable to third-party countermeasures.

\subsection{Third-Party Countermeasures in the Law of State Responsibility}

\subsubsection{Countermeasures as Enforcement of International Law}

Countermeasures allow for states, whose rights have been breached, to take measures in response to the internationally wrongful act of another state (i.e. the breach of an international obligation). ${ }^{134}$ They have been further defined as "pacific unilateral reactions, which are intrinsically unlawful, which are adopted by one or more States against another State, when the former consider that the latter has committed an

\footnotetext{
${ }^{130}$ Barcelona Traction, paras. 33-34. See also Chapter 2.2.2, above.

${ }^{131}$ See Chapter 2.3.2, above.

${ }^{132}$ ARSIWAC (2001), Article 48, paras. 1-2.

${ }^{133}$ Ibid., Article 54, paras. 6-7.

${ }^{134}$ ARSIWAC (2001), Introductory Commentary, Part Three, Chapter II, para. 1.
} 
internationally wrongful act which could justify such a reaction' ${ }^{135}$ The right to take countermeasures in response to a breach of an international obligation is recognised by governments and in decisions of international courts and tribunals as a legitimate form of self-help under general international law. ${ }^{136}$ Countermeasures are limited to strictly pacific measures, which reflects the progressive development of international law relating to armed reprisals. ${ }^{137}$ Countermeasures are a means for the implementation of state responsibility and correspond to the initial breach of an international obligation as well as to the failure of the responsible state to fulfil its secondary obligations of cessation and reparation. ${ }^{138}$ The distinguishing feature of countermeasures is that they are intrinsically unlawful, but justified by being a response to a prior illegality. ${ }^{139}$ Countermeasures therefore also function as a circumstance precluding the wrongfulness of the breach of the rights of the responsible state in accordance with Article 22 ARSIWA. ${ }^{140}$ The right to resort to countermeasures is fundamental in the decentralised international legal order as it is the only means equally available to all states to respond to any breach of an international obligation and to pursue reparations for injuries suffered. ${ }^{141}$ Countermeasures are codified as a circumstance precluding wrongfulness in Article 22 ARSIWA, and in Articles 49-53 as a legal faculty given to the injured state in response to the internationally wrongful act of another state. ${ }^{142}$

The right to take countermeasures is in principle reserved for the injured state, in response to the state responsible for the commission of the internationally wrongful act under Article 49 ARSIWA. Injured states are narrowly defined in Article 42 ARSIWA as the states to which the obligation breached is owed, or the state that is specially affected by the breach of a multilateral obligation. ${ }^{143}$ In this regard, ARSIWA draws an

\footnotetext{
135 Alland (2010), 1135.

${ }^{136}$ Lesaffre (2010), 469.

${ }^{137}$ See Case Concerning the Air Service Agreement of 27 March 1946 between the United States of America and France, arbitral award (1978), para. 81; United States Diplomatic and Consular Staff in Tehran, ICJ, 1980, para. 53; Military and Paramilitary Activities in and against Nicaragua, ICJ (1986), para. 201; Gabcikovo-Nagymaros Project case, ICJ (1997), para. 82.

${ }^{137}$ Crawford (2013), 93-95.

${ }^{138}$ Kolb (2017), 173-174.

${ }^{139}$ ARSIWAC (2001), Introductory Commentary to Part Three, Chapter II, para. 3; and Alland (2002), 1221-1222. Countermeasures are thereby distinguished from acts of retorsion, which consists of lawful measures in response to a prior unfriendly or illegal act by another states, see Kolb (2017), 175-176.

${ }^{140}$ ARSIWAC, Article 22, paras. 1-4.

${ }^{141}$ Alland (2010), 1127-1130.

${ }^{142}$ Crawford (2012), 585-586.

${ }^{143}$ Ibid., Article 42, para. 1.
} 
essential distinction between states directly and indirectly injured by a breach of an international obligation. ${ }^{144}$ States that are directly injured by a breach of an international obligation are entitled to the full range of legal remedies available under ARSIWA, including the right to take countermeasures in the event of a breach of an international obligation. The first situation in Article 42 ARSIWA refers to the breach of an obligation in a bilateral legal relationship between the injured state and the state responsible for the breach of an obligation. ${ }^{145}$ The second situation refers to the breach of a multilateral obligation (i.e. obligations erga omnes or erga omnes partes) where the injured state is differently affected by the breach than other states in the same multilateral legal relationship. ${ }^{146}$ Multilateral obligations of this nature can be described as 'bilateralizable', meaning that a bilateral legal relationship is created between the specially affected state and the responsible state by operation of the law of state responsibility in the event of a breach of an international obligation. ${ }^{147}$ This narrow definition of an injured state builds on the traditional bilateral conception of international law and relationships between states and serves to identify the states implicated by a breach of international law in order to limit the rights of invocation and enforcement to directly injured states. ${ }^{148}$ States other than the injured state have limited rights of invoking breaches of international law where they concern obligations erga omnes (partes) in accordance with Article 48 ARSIWA. ${ }^{149}$

The unilateral character of countermeasures allows states considerable flexibility in interpreting the illegality triggering the right to respond, as well as choosing how to respond to the breach. ${ }^{150}$ Countermeasures are in principle liable to abuse by states seeking to enforce or even to coerce other states, which is aggravated by the flexible definition of countermeasures, the controversial history of countermeasures as associated with forcible reprisals and further by the existence of factual inequalities

\footnotetext{
${ }^{144}$ ARSIWAC, Article 49, paras. 1-9, and Article 42, para. 1; see Shaw, (2017), 605-606.

${ }^{145}$ Ibid., Article 42, paras. 2-3.

${ }^{146}$ Ibid., Article 42, paras. 12-13.

${ }^{147}$ Sicilianos (2002), 1133-1134.

${ }^{148}$ ARSIWAC (2001), Article 42, paras. 4-15; Sachariew (1988), 277-278; Simma, (1989), 823; Annacker (1994), 136; and Hutchinson (1988) 154-155; and generally, Bollecker-Stern (1973).

${ }^{149}$ ARSIWAC (2001), Article 42, paras. 1-3.

${ }^{150}$ Crawford (2013), 685-686; see also ARSIWAC (2001), Introductory Commentary to Part Three, Chapter II, para. 5, concerning that ARSIWA draws no distinction between 'reciprocal' countermeasures and other countermeasures.
} 
between states. ${ }^{151}$ Moreover, a state's decision to take countermeasures will rarely, if ever, be subjected to the scrutiny of an international court or tribunal. ${ }^{152}$ The risks of abuse are mitigated to some extent by a set of legal conditions and procedural safeguards that limit the (lawful) use of countermeasures. ${ }^{153}$ The limitations include the procedural requirements of notification and negotiation prior to the resort to countermeasures, as well as substantive conditions including, inter alia, limitations in the permissible object and purpose, obligations not affected by countermeasures, and proportionality between the countermeasures and the initial internationally unlawful act. ${ }^{154}$ The most important substantive limitation is on the object and purpose of countermeasures to induce the responsible state to comply with its international obligations. ${ }^{155}$ This temporary nature is also reflected in the requirement to terminate the countermeasure once the objective has been achieved, with some degree of reversibility so as to leave the underlying obligation intact. ${ }^{156}$ This is what distinguishes countermeasures from the termination or suspension of treaty relations in response to a material breach in accordance with Article $60 \mathrm{VCLT}$, the recourse to which affects the substantive legal obligations of the states parties so as to restore the contractual balance between them. ${ }^{157}$ By contrast, countermeasures are primarily intended as a tool of enforcement of a right that has been breached, leaving the underlying obligation intact. ${ }^{158}$ In the light of recent developments in international law in the direction of a multilateral dimension of responsibility, the question has been raised whether states other than the injured state should be entitled to respond to breaches of communitarian norms on behalf of the international community (as defined in Article 48 ARSIWA). ${ }^{159}$ The issue of countermeasures by states other than the injured state, third-party countermeasures, is examined in the section below. ${ }^{160}$

\footnotetext{
${ }^{151}$ Crawford (2013), 686.

152 Alland (2010), 1129.

${ }^{153}$ Crawford, Third Report on State Responsibility (2001), paras. 77-78; and Crawford, Fourth Report on State Responsibility (2001), paras. 14-15.

${ }_{154}$ Articles 49-53 ARSIWA.

155 Article 49 ARSIWA.

${ }^{156}$ ARSIWAC (2001), Article 49, paras. 6-7.

${ }^{157}$ On the respective scope of the codified law of treaties and the law of state responsibility, see ARSIWAC (2001), Introductory Commentary to Part One, Chapter VI, paras. 3 and 7.

${ }_{158}$ ARSIWAC (2001), Introductory Commentary to Part Three, Chapter II, para. 4.

${ }^{159}$ Akehurst (1970), 1; Charney (1989), 57; Simma (1994), 217; Frowein (1994), 345.

${ }^{160}$ See Chapter 3.2.2.
} 


\subsubsection{Third-Party Countermeasures in International Law}

The use of third-party countermeasures is one of the most controversial issues in the law of state responsibility. ${ }^{161}$ Third-party countermeasures could ensure the protection of the common interests of the international community. ${ }^{162}$ The dangers of recognising a right to third-party countermeasures relate to fears of providing a pretext for power politics by effectively legitimizing intervention contrary to the principle of non-intervention under Article $2(7)^{163}$ of the UN Charter, all under the guise of lawful countermeasures. In general, the use of third-party countermeasures is also considered to have potentially disruptive effects on the institutional balance established under the UN Charter. ${ }^{164}$

In 2001, the ILC reserved its position on third-party countermeasures by adopting a savings clause on the matter in Article 54 ARSIWA. The provision somewhat ambiguously provides that the chapter on countermeasures 'does not prejudice the right of any State, entitled under article 48, paragraph 1, to invoke the responsibility of another State, to take lawful measures against that State to ensure cessation of the breach and reparation in the interest of the injured State or of the beneficiaries of the obligation breached'. ${ }^{165}$ The ILC Commentary to ARSIWA clarifies that, at the time of adoption, state practice was simply too sparse to include a provision on the right to states to take third-party countermeasures in the situations envisaged under Article 48 ARSIWA. ${ }^{166}$ Consequently, Article 54 ARSIWA neither endorses nor precludes that a right to third-party countermeasures may arise as a result of the further development of international law and the formation of customary international law. ${ }^{167}$ In order to understand the position of the ILC in Article 54 ARSIWA, it is necessary to first briefly consider the ILC's codification of the law of state responsibility. ${ }^{168}$

\footnotetext{
${ }^{161}$ Gaja (2010), 957, 962; and Tams (2010), 390, 397.

${ }^{162}$ Gaja (1989), 156; and Gaja (2013), 130. See further also Frowein (1994), 423; Alland (2002), 1239;

Villalpando (2005), 371, 410, Orakhelashvili (2006), 272; Katselli Proukaki (2010), 10, 281-281; and Tams (2005), 158.

${ }^{163}$ Article 2(7) of the UN Charter provides that '[n]othing contained in the present Charter shall authorize the United Nations to intervene in matters which are essentially within the domestic jurisdiction of any state or shall require the Members to submit such matters to settlement under the present Charter...'. ${ }_{164}$ Dawidowicz (2017), 8-13.

${ }^{165}$ Article 54 of ARSIWA.

${ }^{166}$ ARSIWAC (2001), Article 54, paras. 3-7.

${ }^{167}$ Ibid., para. 7.

${ }^{168}$ For a comprehensive overview of the codification process, see further Sicilianos (2005) 447-500; and on third-party countermeasures, Dawidowicz (2017), 72-110.
} 
The first version of the draft Articles, adopted in 1996, contained a series of provisions that appeared to (at least implicitly) recognise a right to third-party countermeasures in response to breaches of communitarian norms. ${ }^{169}$ Draft Article 19 [1996] established a differentiated regime of state responsibility on the basis of the relative importance of the obligation breached: international crimes, for breaches of obligations of fundamental importance to the international community as a whole; and international delicts, for the broader category of internationally wrongful acts of lesser importance. ${ }^{170}$ The provision reflected proposals made by Special Rapporteur Ago early in the codification process. ${ }^{171}$ State crimes entailed all the legal consequences of any other internationally wrongful act as well as certain further consequences, such as the obligations of non-recognition, non-assistance and non-cooperation. ${ }^{172}$ In the event of the commission of an international crime, all states would be considered injured under the broad definition of draft Article 40 [1996], ${ }^{173}$ reflecting proposals made by Special Rapporteur Riphagen. ${ }^{174}$ At the same time, draft Article 47 [1996] provided that any injured state had the right to take countermeasures. ${ }^{175}$ Read together with the distinction between international crimes and delicts in draft Article 19 [1996] and the broad definition of injured states in draft Article 40 [1996], the ILC appeared to, either implicitly or as the result of poorly coordinated drafting, recognise the right to third-party countermeasures in the 1996 draft Articles. ${ }^{176}$ Riphagen's successor as Special Rapporteur, Arangio-Ruiz, had initially proposed an elaborate regime of safeguards designed to limit the risks associated with the regime of countermeasures in response to state crimes. ${ }^{177}$ The regime, based on so-called 'the indispensable role of international institutions', involved a primary assessment of a political nature by the General Assembly or the Security Council, followed by a decisive legal determination by the ICJ upon application of the

\footnotetext{
${ }^{169}$ Crawford (2013), 703-708.

${ }^{170}$ Generally, see Spinedi (1989).

${ }_{171}$ Ago, Fifth Report on State Responsibility (1976), paras. 24-54.

${ }^{172}$ ILC, Report of the Drafting Committee: State Responsibility - Draft Articles Provisionally Adopted by the Drafting Committee on Second Reading (1996), para. 60, draft Articles 51 and 53 [1996].

${ }^{173}$ Ibid., draft Article 40 [1996].

${ }^{174}$ Riphagen, Sixth Report on State Responsibility (1985), paras. 9, 14.

${ }^{175}$ ILC, Report of the Drafting Committee: State Responsibility - Draft Articles Provisionally Adopted by the Drafting Committee on Second Reading (1996), para. 60, draft Article 47 [1996].

${ }^{176}$ ILC, Report of the Drafting Committee: State Responsibility - Draft Articles Provisionally Adopted by the Drafting Committee on Second Reading (1996), para. 60, draft Articles 51 and 53 [1996]; see also Sicilianos (2005), 484; and Crawford (2013), 703-708.

${ }^{177}$ Arangio-Ruiz, Fifth Report on State Responsibility (1993), 28-30, para. 106.
} 
state seeking to take countermeasures. ${ }^{178}$ The proposals were eventually rejected by the ILC for being too broad and unrealistic, which concluded that the normal safeguards regime would apply also to responses to state crimes. ${ }^{179}$ With regard to state crimes, the ILC later stated that '[i]n practice it is likely that [a] collective response will be coordinated through the competent organs of the United Nations. It is not the function of the present draft articles to regulate the extent or exercise of the constitutional power and authority of the UN organs - nor, in view of Article 103 of the Charter, is it even possible to do so'. ${ }^{180}$ Despite ambiguities in the 1996 draft, no additional safeguards regime was adopted to limit the use of countermeasures in response to state crimes. ${ }^{181}$

In 2000, Special Rapporteur Crawford made a number of key proposals aimed at resolving the ambiguities of the draft adopted on first reading. ${ }^{182}$ State crimes would be decriminalised, and the differentiated regime of state responsibility replaced with a single regime of responsibility. ${ }^{183}$ A distinction would be drawn between bilateral and multilateral obligations and between directly and indirectly injured states, reflecting the ICJ's pronouncements in the Barcelona Traction case. ${ }^{184}$ States not directly injured by a breach would have limited rights to invoke a breach of a multilateral obligation, secondary to that of the directly injured state. ${ }^{185}$ These proposals were eventually adopted in draft Articles 42 and 48 [2001]. ${ }^{186}$ Crawford also proposed to include a regime of 'collective countermeasures' (i.e. third-party countermeasures) in the draft Articles. ${ }^{187}$ Although state practice was limited at the time, Crawford considered that it did suggest that a right to third-party countermeasures might be envisaged in situations in which the directly injured state requested the assistance of a third state, or in the event of a breach of an obligation erga omnes with no directly injured state such as breaches of human rights or humanitarian law affecting only the nationals of the

\footnotetext{
${ }_{178}$ Arangio-Ruiz, Seventh Report on State Responsibility (1995), 17, paras. 70-140.

${ }^{179}$ UNGA, Topical Summary of Government Comments in the Sixth Committee (1995), paras. 86-97.

${ }^{180}$ Cf. ARSIWAC (2001), Article 40, para. 9.

${ }^{181}$ Sicilianos (2005) 490-492.

${ }^{182}$ See further Crawford, Third Report on State Responsibility (2000).

${ }^{183}$ Application of the Convention on the Prevention and Punishment of the Crime of Genocide, ICJ

(2007), para. 170, in which the ICJ considered that 'international law does not recognise the criminal responsibility of the state'.

184 Barcelona Traction, paras. 33-34.

${ }^{185}$ See further Crawford, Third Report on State Responsibility (2000).

${ }^{186}$ ARSIWAC (2001) clarifies that this distinction is based on the Barcelona Traction dictum; on the legal standing for breaches of obligations erga omnes partes, see Questions Relating to the Obligation to Prosecute or Extradite (Belgium v. Senegal), Judgment, I.C.J. Reports 2012, 422.

${ }^{187}$ YbkILC (2000), Vol. II(2), 70-71.
} 
responsible state. ${ }^{188}$ In the latter situation, Crawford considered that to disallow thirdparty countermeasures in response to 'gross and well-attested breaches of obligations erga omnes ${ }^{189}$ may 'place further pressure on States to intervene in other, perhaps less desirable ways ${ }^{190}$ and that '[i]nternational law should offer to States with a legitimate interest in compliance with such obligations, some means of securing compliance which does not involve the use of force'. ${ }^{191}$

The proposal to include a regime of third-party countermeasures was met with strong opposition in both the ILC and in debates of the Sixth Committee. On the one hand, several members of the ILC considered that the article was a 'necessary' provision for dealing with serious breaches of obligations erga omnes'. ${ }^{192}$ Interestingly, it was remarked that "leaving it up to the "organised international community", i.e. the United Nations to react to breaches of obligations erga omnes bordered on cynicism'. ${ }^{193}$ On the other hand, several members called for the deletion of the article based on inconsistencies in state practice and the dangers of recognising a regime of third-party countermeasures. ${ }^{194}$ The regime of third-party countermeasures would open for bullying of third states on the claim that human rights must be respected, installing a 'do-ityourself' sanctions system without the safeguards of the collective mechanisms under Chapter VII of the UN Charter. ${ }^{195}$ In principle, the regime of third-party countermeasures 'extended to questions which fell under Article 41 of the Charter of the United Nations, while circumventing the security system which the latter had set up to safeguard the rights of all States'. ${ }^{196}$ As the protection of fundamental interests was in principle a matter already regulated by Chapter VII of the UN Charter, there was no imperative need to recognise a parallel system of enforcement of communitarian norms. ${ }^{197}$ The debate in the Sixth Committee raised essentially the same issues as the ones in the ILC. A diverse group of states made statements of expressing varying

\footnotetext{
${ }^{188}$ See Crawford (2013), 703.

${ }^{189}$ Crawford, Third Report on State Responsibility (2000), para. 405.

${ }^{190}$ Ibid.

${ }^{191}$ Ibid.

192 YbkILC (2001), Vol. I, 40, para. 41 (Mr. Economides); 41, para. 49 (Mr. Pellet).

${ }^{193}$ YbkILC (2000), Vol. I, 305, para. 31 (Mr. Simma); and YbkILC (2001), Vol. I, 35 para. 4 (Mr. Simma).

${ }^{194}$ YbkILC (2001), Vol. I, 35, para. 2 (Mr. Brownlie).

${ }^{195}$ Ibid., and Brownlie (2008), 515.

${ }^{196}$ YbkILC (2001), Vol. I, 54, para. 3 (Mr. Elaraby).

${ }^{197}$ See YbkILC (2000), Vol. I, 336, para. 34, 44 (Mr. Sepulveda-Amor); 54, para. 26 (Mr. Tomka).
} 
degrees of support for the provision, commending the efforts to establish a public law enforcement system for breaches of communitarian norms, including Western and European states (Spain, Slovenia, Germany, Austria, Italy, France, Switzerland, New Zealand, Australia, and Finland, on behalf of the Nordic countries), ${ }^{198}$ South and Central American states (Chile, Argentina, Costa Rica), ${ }^{199}$ as well as Mongolia ${ }^{200}$ and South Africa. ${ }^{201}$ The Netherlands, Greece, Poland and Jordan made statements to the effect that third-party countermeasures should be limited to situations where the Security Council is actively seized with a matter or is taking enforcement measures under Chapter VII of the UN Charter. ${ }^{202}$ However, there was strong opposition to the regime of third-party countermeasures from several states, including Mexico, Libya, Algeria, Colombia, Iran and Cuba, considering that it lacked support in international law and was incompatible with the UN Charter. ${ }^{203}$ States including Brazil, Cameroon, Morocco, Russia, Israel, the US, India, China, Botswana, Tanzania and Japan stressed that the responses to violations of obligations erga omnes were already defined by the legal order established under Chapter VII of the UN Charter. ${ }^{204}$ The regime of third-party countermeasures would not only unacceptably create a parallel enforcement mechanism to that of the Security Council under Chapter VII, but also undermine the power of the latter with potentially disruptive and destabilising effects. ${ }^{205}$

\footnotetext{
${ }^{198}$ See statements by Slovenia (UN Doc. A/C.6/55/SR.18, 6, para. 27); Germany (UN Doc. A/C.6/55/SR.14, 10, para. 54); Austria (UN Doc. A/CN.4/515, 88-92); Italy (UN Doc. A/C.6/55/SR.16, 5, para. 28); France (UN Doc. A/CN.4/515/Add.2, 15-16, 18); Switzerland (UN Doc. A/C.6/55/SR.18/, 14, para. 81); New Zealand (UN Doc. A/C.6/56/SR.11, 8, para. 46); Australia (UN Doc. A/C.6/55/SR.16, 7, para. 41); and Finland, on behalf of the Nordic countries (UN Doc. A/C.6/56/SR.11, 5, para. 30).

${ }^{199}$ See statements by Chile (UN Doc. A/C.6/55/SR.17, 8, para. 48); Argentina (UN Doc. A/C.6/55/SR.15, 10, para. 66); and Costa Rica (UN Doc. A/C.6/55/SR.17, 11, para. 63).

${ }^{200}$ See statement by Mongolia (UN Doc. A/C.6/56/SR.14, 9, para. 56).

${ }^{201}$ See statement by South Africa (UN Doc. A/C.6/56/SR.12, 5, para. 23).

${ }^{202}$ See statements by the Netherlands (UN Doc. A/CN.4/515, 87); Greece (UN Doc. A/CN.6/55/SR.17, 14, para. 85); Poland (UN Docs. A/CN.4/515/Add.2, 18-19, A/C.6/55/SR.18, 9, para. 48); and Jordan (UN Doc. A/C.6/55/SR.18, 4, para. 15).

${ }^{203}$ Mexico (UN Doc. A/CN4/515/Add.1, 9-10); Libya (UN Doc. A/C.6/55/SR.22, 8, para. 52); Algeria (UN Doc. A/C.6/55/SR.18, 2, para. 5); Colombia (UN Doc. A/C.6/56/SR.16, 7, para. 40); Iran (UN Doc. A/C.6/55/SR.15, 3, para. 17); and Cuba (UN Doc. A/C.6/55/SR.18, 11, para. 59).

${ }^{204}$ See statements by Brazil (UN Doc. A/C.6/56/SR.16, 2, para. 4); Cameroon (UN Doc. A/C.6/55/SR.24, 11, para. 64); Morocco (UN Doc. A/C.6/56/SR.11, 7, para. 39); Russia (UN Doc. A/C.6/55/SR.18, 9, para. 51); Israel (UN Doc. A/C.6/55/SR.15, 5, paras. 24-25); the US (UN Doc. A/CN.4/515, 52-53); India (UN Doc. A/C.6/55/SR.15, paras. 29, 31); China (UN Doc. A/CN.4/515, 69-70, A/C.6/56/SR.11, 10, paras. 59, 62); Botswana (UN Doc. A/C.6/55/SR.15, 10, para. 63); Tanzania (UN Doc. A/C.6/55/SR.14, 9, paras. 46-47); and Japan (UN Doc. A/CN.4/515, 79).

${ }^{205}$ See the statement by Mexico (UN Doc. A/CN4/515/Add.1, 9-10).
} 
Moreover, states in the Sixth Committee appeared to express a preference for enforcement measures at the institutional level by the Security Council. Mexico considered that ' $[\mathrm{t}] \mathrm{he}$ response to a serious violation of this type has already been clearly defined in the legal order established by the Charter itself... [I]t would be unacceptable to introduce a mechanism that would change the collective security system enshrined in the Charter and allow for the taking of collective countermeasures, unilaterally decided, without intervention of the central organ of the international community'. ${ }^{206}$ Similarly, Israel considered that the regime of third-party countermeasures would have 'a destabilizing effect by creating a parallel mechanism for responding to serious breaches, which lacked the coordinated, balanced, and collective features of existing mechanisms'. ${ }^{207}$ Furthermore, the relationship between the use of third-party countermeasures and Security Council enforcement measures under Chapter VII of the UN Charter was considered unclear and not resolved by what became Article 59 ARSIWA, 'since the Charter itself did not establish whether Security Councilmandated measures automatically entailed the cessation of countermeasures by States or whether the two types of measures could be implemented simultaneously without violating the principle of proportionality'. ${ }^{208}$ In sum, the arguments raised by states in the Sixth Committee regarding the relationship between third-party countermeasures and the Security Council's mandate relating to the coherence of the international legal order in terms of the institutional balance established under the UN Charter, with the Security Council as the main guardian of community interests. ${ }^{209}$

Following strong opposition to the proposal for a regime of third-party countermeasures in the draft Articles, a compromise solution was found in the adoption of Article 54 ARSIWA. ${ }^{210}$ The unclear relationship between third-party countermeasures and the UN Charter was considered particularly difficult to resolve without straying into the

\footnotetext{
206 Ibid.

${ }^{207}$ See statements by Israel (UN Doc. A/C.6/55/SR.15, 5 para. 25); and the US (UN Doc. A/CN.4/515, 52-53).

${ }^{208}$ See statements by Cameroon (UN Doc. A/C.6/55/Sr.24, 11, para. 64); see also the same point by Morocco (UN Doc. A/C.6/56/SR.11, 7, para. 39), suggesting an analogy to Article 51 UNC on selfdefence, i.e. that a third state should cease its third-party countermeasures once the Security Council had ordered collective economic sanctions, To the same effect, see also the statements made by Russia (UN Doc. A/C.6/56/SR.14, 7, para. 44); and India (UN Doc. A/C.6/55/SR.15, paras. 29, 31). On the principle of proportionality, see Chapter 3.4, below.

${ }^{209}$ See Chapter 2.3, above.

${ }^{210}$ Crawford, Fourth Report on State Responsibility (2001), paras. 72-73.
} 
territory of primary norms and moving beyond the savings clause in what would become Article 59 ARSIWA. $^{211}$ The reference to 'lawful measures' in Article 54 ARSIWA was deliberate 'so as not to prejudice any position concerning measures taken by states other than the injured state in response to breaches of obligations for the protection of the collective interest or those owed to the international community as a whole'. ${ }^{212}$ The savings clause therefore '[reserved] the position of all those who believed that the right to take countermeasures should be granted to States other than the injured State with regard to the breaches of obligations established to preserve collective interests and those who believed that only injured States should have the right to take countermeasures'. ${ }^{213}$ Therefore the ILC neither endorsed nor precluded that a right to third-party countermeasures may arise as a result of the formation of customary international law, leaving the resolution of the matter to the further development of international law. ${ }^{214}$ The legal position of the right to resort to third-party countermeasures in response to breaches of obligations erga omnes is therefore unclear in the final draft of ARSIWA.

\subsection{Third-Party Countermeasures in State Practice}

\subsubsection{Introduction}

The current legal status of third-party countermeasures must be determined on the basis of an examination of state practice, given the inconclusive position in the savings clause in Article 54 ARSIWA. $^{215}$ In 2001, the ILC took a cautious approach by determining, on the basis of a relatively small number of examples, that state practice was too limited to formally include a right to third-party countermeasures in the final draft of ARSIWA. ${ }^{216}$ There are a small number of studies examining state practice that have

\footnotetext{
${ }^{211}$ Ibid.; Crawford, Third Report on State Responsibility (2000), paras. 422-426, 429 (on what became Art. 59 ARSIWA); and Crawford (2013), 706-711.

${ }^{212}$ YbkILC (2001), Vol. II(2), para. 139.

${ }^{213}$ YbkILC (2001), Vol. I, para. 48 (Chairman of the Drafting Committee, Mr. Tomka).

${ }^{214}$ ARSIWAC (2001), Article 54, paras. 6-7.

215 See Chapter 3.2.2, above.

${ }^{216}$ ARSIWAC (2001), Article 54, para. 6. See also Crawford, Fourth Report on State Responsibility (2001), paras. 71-74; and Crawford, Third Report on State Responsibility (2000), para. 396; and Dawidowicz (2006), 409.
} 
rejected this argument. ${ }^{217}$ These studies confirm the existence of what is in reality a rather substantial body of state practice of third-party countermeasures, one that appears to be accompanied by the appropriate elements of opinio juris. ${ }^{218}$

The purpose of the following sections is not to determine the existence of a right to third-party countermeasures under customary international law, but to briefly systematise previous studies of state practice. A preliminary observation is that thirdparty countermeasures have been taken in response to breaches that can be broadly categorised as either violations of human rights and humanitarian law, or illegal uses of force. In the first category, third-party countermeasures have been taken in response to violations of human rights and humanitarian law. ${ }^{219}$ In the majority of these cases, the breaches have amounted to violations of peremptory norms of international law that give rise to clearly identifiable obligations erga omnes, such as apartheid, acts of genocide, self-determination claims, or the practice of torture. ${ }^{220}$ Other violations falling into this category are norms of a non-peremptory character that give rise to less easily identifiable obligations erga omnes, but which are likely candidate to acquire such status if they have not already done so. These include human rights such as the right to life, fair trial guarantees, the freedom of expression, the freedom from arbitrary detention, and similar obligations. ${ }^{221}$ In the second identified category, third-party countermeasures have been adopted in response to violations of the prohibition on the use of force, typically in situations involving the illegal invasion by one state of the territory of another. The prohibition of the use of force is a peremptory norm of international law, meaning that it gives rise to an easily identifiable obligation erga omnes. $^{222}$ The fundamental role of the prohibition of the use of force under the UN Charter means that a situation involving a breach of the use of force falls squarely within the competences of the Security Council and may become subject to institutional enforcement. $^{223}$

\footnotetext{
${ }^{217}$ Tams (2005), 198-251; Katselli Proukaki (2010), 90-209; Dawidowicz (2017), 111 ff. See also Sicilianos (1990), 155-169; and Dawidowicz (2006), 333-418.

${ }_{218}$ See for example Dawidowicz (2017), 382-385.

${ }^{219}$ Dawidowicz (2006), 418.

${ }^{220}$ Tams (2005), 232-233.

${ }^{221}$ Ibid., 233.

222 Ibid., 233.

${ }^{223}$ See Chapter 2.3.2, above.
} 


\subsubsection{Third-Party Countermeasures in Response to Violations of}

\section{Human Rights and International Humanitarian Law}

Violations of human rights and humanitarian law are among the most common breaches of international law to which states have responded with third-party countermeasures. ${ }^{224}$ Western states dominate the state practice of third-party countermeasures, responding to several major international crises of the last decades. In the human rights and humanitarian law context, Western states have responded by non-forceful means to breaches of human rights and humanitarian law in the Former Republic of Yugoslavia in both 1991 and 1998-2000, following the large-scale repression and ethnic cleansing of ethnic Albanians in Kosovo, in the form of an arms embargo, travel bans, suspension of export credit, and an asset freeze; ${ }^{225}$ the United States and European Community member states responded to the situation in Sudan by asset freezes and other measures in $1997-2005 ;^{226}$ and the asset freezes taken by Switzerland and the United States against Libya, including following violent repression of anti-government protests and widespread human rights abuses in $2011 .^{227}$

In a smaller number of cases, non-Western states have either adopted or expressed support for the adoption of third-party countermeasures. In particular, African states have adopted countermeasures in response to widespread human rights abuses committed on the African continent, on a number of occasions. An early example are the unilateral coercive measures taken in 1960-1964 against South Africa by several developing countries, including Ghana, Malaysia, Nigeria, Indonesia, Kuwait, Pakistan, Sierra Leone, Tanganyika (currently Tanzania) and Uganda, in the form of a trade embargo in response to the illegal regime of apartheid. ${ }^{228}$ A little over two decades later, several Western and non-Western states took unilateral coercive measures anew against South Africa on the basis of a new constitution in the country, which entrenched the illegal policy of apartheid in the country, as well as the brutal acts of political repression

\footnotetext{
${ }^{224}$ Dawidowicz (2006), 417-418.

${ }^{225}$ Dawidowicz (2017), 181-193; Tams, (2005), 223-224; and Katselli Proukaki (2010), 191-196.

${ }^{226}$ See Chapter 4.3.2, below.

${ }^{227}$ See Chapter 4.3.3, below.

${ }^{228}$ Dawidowicz (2017), 113-117; and Katselli Proukaki (2010), 165-177.
} 
and widespread violence. ${ }^{229}$ The General Assembly not only welcomed but had also previously called for measures to be taken against South Africa, 'pending action by the Security Council'. ${ }^{230}$ Other examples include measures taken in 1980, by European and African states, against Liberia in response to the serious human rights abuses committed in the aftermath of a coup d'état in the country; ${ }^{231}$ in 1996, by European and Commonwealth States against Nigeria for its suppression of civil and political rights, brutal repression of protests and denial of fair trial rights; ${ }^{232}$ in 1996, by several African states, against Burundi for widespread human rights abuses committed in the country, including inter-ethnic massacres; ${ }^{233}$ in 2002-2003, when EU member states, with support from twenty-five aligned states, adopted countermeasures against Zimbabwe in response to its suppression of civil and political rights in the country, violence and serious human rights abuses, in the form of asset freezes, an arms embargo, travel bans, and the suspension of financial aid and development assistance under the Cotonou Agreement, alongside countermeasures adopted by Switzerland, Commonwealth States, the US and Canada. ${ }^{234}$

Recent state practice of third-party countermeasures confirms that it is of a widespread and representative nature. In May 2011, in response to widespread and systematic violations of human rights and humanitarian law committed in Syria, the EU imposed economic unilateral sanctions against the country, including an arms embargo as well as freezing assets belonging to President Al-Assad and the Central Bank of Syria. ${ }^{235}$ The Arab League member states either adopted or expressed strong support for third-party countermeasures against Libya and Syria in the form of inter alia freezing of assets and suspension of air service agreements. In addition, Arab League and OIC member states took action by suspending Syria from membership in the organisations without clear legal support for doing so under their respective Charters. ${ }^{236}$

\footnotetext{
${ }^{229}$ See Dawidowicz (2017), 154-159; and Katselli Proukaki (2010), 165-177.

${ }^{230}$ UNGA Res. 40/64(A) (1985), para. 9.

${ }^{231}$ Dawidowicz (2017), 126-127; and Katselli Proukaki (2010), 135.

${ }^{232}$ Dawidowicz (2017), 162-176; and Katselli Proukaki (2010), 189-190.

${ }^{233}$ Dawidowicz (2017), 168-176; and Katselli Proukaki (2010), 190.

${ }^{234}$ Dawidowicz (2017), 203-211; and Katselli Proukaki (2010), 197-198.

${ }^{235}$ Council Decision 2011/273/CFSP of 9 May 2011; and Council Decision 2011/782/CFSP of 1 December 2011.

236 'Arab League Decides to Suspend Syria', Al-Jazeera (13 November 2011); and 'Organisation of Islamic Cooperation Suspends Syria’, Alsharif, A., Reuters (16 August 2012).
} 
An even more recent example of practice is the unilateral responses to the violations of human rights and humanitarian law committed in Myanmar against the Muslim Rohingya minority, a 'textbook example of ethnic cleansing' ${ }^{237}$ In August 2018, a United Nations-mandated fact-finding mission in its report established 'consistent patterns of serious human rights violations and abuses in Kachin, Rakhine and Shan States, in addition to serious violations of international humanitarian law'. It identified on reasonable grounds conduct amounting to acts of genocide, crimes against humanity, and war crimes, i.e. breaches of international humanitarian law. ${ }^{238}$ On 21 December 2018, the EU imposed sanctions in the form of travel bans and the freezing of assets of high-ranking officials of the Myanmar military, for serious human rights violations committed against the Rohingya population, ethnic minority villagers and civilians, some of which 'amounted to the gravest crimes under international law'. ${ }^{239}$ Ten countries have aligned themselves with the EU measures, including Turkey, Northern Macedonia, Montenegro, Albania, Bosnia and Herzegovina, Iceland, Liechtenstein, Norway, Moldova and Armenia. ${ }^{240}$ The US has imposed sanctions against Myanmar in August 2018, comprising of economic measures targeting high-ranking military and police officials, as well as two military units, for their involvement in the ethnic cleansing in Rakhine State and other widespread human rights abuses in Kachin and Shan States. ${ }^{241}$ The asset freezes imposed against Myanmar by the EU and the US, respectively, are prima facie unlawful measures that require justification under general international law. ${ }^{242}$ In the absence of such justification, these measures are best understood as third-party countermeasures. The recent situation in Myanmar has not yet been subject to meaningful institutional enforcement action by the Security Council

\footnotetext{
${ }^{237}$ OHCHR, Darker and More Dangerous: High Commissioner Updates the Human Rights Council on Human Rights Issues in 40 Countries, Opening Statement by Zeid Ra'ad Al Hussein, UN High Commissioner for Human Rights at the $26^{\text {th }}$ session of the HRC (2017).

${ }^{238}$ HRC, Report of the Independent International Fact-Finding Mission on Myanmar (2018); and see also UNHRC Res. 34/22.

${ }^{239}$ Council Decision (CFSP) 2018/2054 (2018); Council Implementing Regulation (EU) 2018/2053 (2018); and Council of the EU Press Release 822/18 (2018). See also Council Implementing Regulation 2019/672 (2019) and Council Decision (CFSP) 2019/678 (2019).

${ }^{240}$ Council of the EU, Declaration by the High Representative on behalf of the EU on the alignment of certain countries with Council Decision concerning restrictive measures against Myanmar/Burma (7 February 2019).

${ }^{241}$ US Department of the Treasury, Treasury Sanctions Commanders and Units of the Burmese Security Forces for Serious Human Rights Abuses (17 August 2018).

${ }^{242}$ See Criddle (2013) 590-593.
} 
under Chapter VII of the UN Charter. ${ }^{243}$ So far, only verbal condemnations have been made by the General Assembly ${ }^{244}$ and the Human Rights Council. ${ }^{245}$

The list of practice of third-party countermeasures might also be expanded to include the various sanctions adopted against Venezuela in response to the (as of May 2019) still on going serious human rights abuses committed in the context of protests in the country. ${ }^{246}$ Third-party countermeasures have so far been adopted by a number of states acting unilaterally. In November 2017, EU member states imposed restrictive measures in view of the continuing deterioration of democracy, rule of law and human rights in the country. ${ }^{247}$ The US has imposed sanctions against Venezuela for more than a decade as a policy tool in response to the activities of the Venezuelan government including sanctions relating to terrorism, drug trafficking, trafficking of persons, antidemocratic actions, violations of human rights and corruption. ${ }^{248}$ On 28 January 2019, the US announced economic sanctions on Venezuela's state-oil company. ${ }^{249}$ In response to the human rights abuses committed in the country, the US imposed sanctions on 1 November 2018 including the freezing of assets and transactions. ${ }^{250}$ The asset freezes can be understood as third-party countermeasures, as they in principle require justification under general international law. ${ }^{251}$ Several of the trade restrictions are contrary to international obligations arising under the $\mathrm{GATT}^{252}$ and WTO law, and can therefore also be understood as third-party countermeasures. ${ }^{253}$ The situation in Venezuela has not yet been subject to any meaningful action at the institutional level, with political disagreement in the Security Council (primarily between the United States

\footnotetext{
${ }^{243}$ Statement by the President of the Security Council (6 November 2017).

${ }^{244}$ UNGA Res. 72/248 (2017).

${ }^{245}$ UNHRC Res. 39/2 (2018); and OHCHR, Human rights violations in the Bolivarian Republic of Venezuela: A Downward Spiral With No End In Sight (2018).

${ }^{246} \mathrm{OHCHR}$, Human Rights Violations in Venezuela: a downward spiral with no end in sight (2018).

${ }^{247}$ Council decision (CFSP) 2017/2074 and Council Regulation (EU) 2017/2063.

${ }^{248}$ For a brief overview of US sanctions against Venezuela, see Congressional Research Service, 'Venezuela: Overview of U.S. Sanctions' (8 May 2019).

${ }^{249}$ The US, Executive Order 13857: Taking Additional Steps to Address the National Emergency With Respect to Venezuela (January 25, 2019).

${ }^{250}$ The US, Executive Order 13850: Blocking Property of Additional Persons Contributing to the Situation in Venezuela (1 November 2018).

${ }^{251}$ See Criddle (2013), 590-593.

${ }^{252}$ GATT 1994: General Agreement on Tariffs and Trade 1994, 15 April 1994, Marrakesh Agreement Establishing the World Trade Organisation, Annex 1A, 1867 UNTS 187, 33 I.L.M. 1153 (1994) [hereinafter GATT].

${ }^{253}$ Venezuela has been a member of the WTO since 1 January 1995 and a member of GATT since 31 August 1990.
} 
and Russia) preventing the adoption of any resolution on the matter. ${ }^{254}$ However, the Human Rights Council adopted a resolution on the matter on 27 September 2018, expressing its 'deep concern at the serious human rights violations in a context of political, economic, social and humanitarian crisis' and calling upon the government of Venezuela to accept humanitarian assistance and urging it to cooperate with the OHCHR and the mechanisms of the Human Rights Council, establishing an Independent, Impartial Investigative Mechanism to collect and preserve evidence of the crimes committed in Myanmar. ${ }^{255}$

\subsubsection{Third-Party Countermeasures in Response to Violations of the Prohibition of the Use of Force}

In some instances, states have taken third-party countermeasures in response to violations of the prohibition of the use of force under Article 2(4) of the UN Charter. The earliest example of state practice is measures taken by the United States against North Korea and China for the invasion of South Korea in $1950 .{ }^{256}$ Further, in 1980, Western countries took unilateral coercive measures against the Soviet Union for the invasion of Afghanistan in late $1979 .{ }^{257}$ Another commonly cited instance of practice is the measures taken by Western countries against Argentina in response to its invasion of the Falkland Islands (Islas Malvinas) in $1982 .{ }^{258}$ In 1990, several states took unilateral measures against Iraq in response to Iraq's invasion and occupation of Kuwait in $1990 .^{259}$ In these instances, the states had violated the principle of the non-use of force, a norm of clear peremptory character and giving rise to clearly identifiable obligations erga omnes. ${ }^{260}$ However, the majority of these measures were taken during the Cold War period (with the exception of measures taken against Iraq in 1990) and must be

\footnotetext{
${ }^{254}$ See competing draft UNSCR of the US, S/2019/186 (2019), vetoed by China and Russia; and the Russian draft resolution S/2019/190 (2019), vetoed by the US.

${ }^{255}$ UNHRC Res. 39/1 (2018).

${ }^{256}$ Katselli Proukaki (2010), 114; and Dawidowicz (2006), 351.

${ }^{257}$ Katselli Proukaki (2010), 135-141; Dawidowicz (2017), 127-133.

${ }^{258}$ Katselli Proukaki (2010), 156-163; Dawidowicz (2017), 140-149; Tams (2005), 215-217. See also further Acevedo (1984), 323-344.

${ }^{259}$ Katselli Proukaki (2010), 178-181; Dawidowicz (2017), 159-162; Tams (2005), 219-220.

${ }^{260}$ Tams (2005), 233.
} 
understood in the context of ineffective enforcement action at the institutional level by the Security Council. ${ }^{261}$

The most recent example of state practice of third-party countermeasures are measures taken in response to Russia's invasion, occupation and annexation of Crimea in $2014{ }^{262}$ On 28 February 2014, Russia invaded and occupied the Ukrainian territory of Crimea, acting in contravention of its obligations under the UN Charter and customary international law. ${ }^{263}$ Russia then formally annexed Crimea on 18 March 2014 following the results of an illegitimate independence referendum organised in Crimea. ${ }^{264}$ The situation in Ukraine progressively destabilised, with several self-proclaimed 'People's Republics' in regions of Eastern Ukraine claiming their independence by sham referenda in order to seek union with Russia. A civil war soon broke out in parts of Eastern Ukraine between pro-Russian separatists and the government in Kiev. ${ }^{265}$ Following strongly worded verbal condemnations, ${ }^{266}$ unilateral coercive measures were taken by predominantly Western states, including Canada, France, Germany, Italy, Japan, the UK and the United States, with support of other EU states, against Russia for its role in the destabilisation of Ukraine. The EU took measures including a travel ban and asset freezes aimed at individuals involved in the events, targeting key parts of the Russian economy, including the financial, defence and energy sectors. ${ }^{267}$ The financial measures appear to violate the obligation to provide most favourable nation treatment under Article II GATS, ${ }^{268}$ and the limited export embargo applicable to energy-related goods may amount to quantitative trade restrictions that are unlawful under Article XI

\footnotetext{
${ }^{261}$ On the Security Council during the Cold War period, see Ugarte and Genser (2014), 7-14.

262 Dawidowicz (2017), 231-238.

263 'Russian "invasion" of Crimea fuels fear of Ukraine conflict', The Guardian (1 March 2014).

${ }^{264}$ UNGA Res. 68/262 (2014); see also OHCHR, Report on the Human Rights Situation in Ukraine (2014), para. 6; and 'Russia Marks Five Years Since Annexation of Ukraine's Crimea', Al-Jazeera (18 March 2019).

265 'East Ukraine Separatists Seek Union with Russia', BBC News (12 May 2014).

${ }^{266}$ See the statement of G7 Leaders on Ukraine (2 March 2014); and Statement by EU Foreign Ministers (3 March 2014).

${ }_{267}$ Council Decision 2014/145/CFSP (2014); and Council Implementing Decision 2014/151/CFSP (21 March 2014).

${ }^{268}$ Article XII GATS provides member states with the possibility of adopting or maintaining restrictions on trade in services, including on payments or transfers for transactions. See GATS: General Agreement on Trade in Services, 15 April 1994, Marrakesh Agreement Establishing the World Trade Organisation, Annex 1B, 1869 UNTS 183, 33 I.L.M 1167 (1994) [hereinafter GATS].
} 
GATT ${ }^{269}$ In the absence of alternative justifications, these measures can be understood in terms of third-party countermeasures. ${ }^{270}$ Other states including Switzerland, the United States, Australia, Canada and Japan took similar measures in coordination with the EU measures initially adopted. ${ }^{271}$ For its part, Russia has stressed the illegitimacy of the unilateral coercive measures taken against it, considering that the measures are in contravention of the UN Charter and general international law. ${ }^{272}$ The Security Council was largely incapacitated throughout due to the exercise of the veto power by Russia. ${ }^{273}$ However, the General Assembly adopted a resolution whereby it reaffirmed its commitment to the territorial integrity of Ukraine and underscored the invalidity of the Crimean referendum held in March 2014. ${ }^{274}$ The General Assembly has also adopted a number of human rights-oriented resolutions on the human rights situation in Crimea and Eastern Ukraine. ${ }^{275}$

\subsection{Legal Conditions and Procedural Safeguards}

The risks of abuse inherent in countermeasures are mitigated to some extent by a set of legal conditions and procedural safeguards for their use under Articles 49-53 ARSIWA. ${ }^{276}$ The set of substantive legal conditions applicable to countermeasures place limitations on the permissible object and purpose of such measures, ${ }^{277}$ and specify the legal obligations that cannot be affected by countermeasures, ${ }^{278}$ as well as the requirement of proportionality. ${ }^{279}$ The procedural safeguards ensure that the wrongdoing state receives notification of the injured state's decision to take countermeasures to

\footnotetext{
${ }^{269}$ Article XI GATT provides a general prohibition on quantitative restrictions on the importation or exportation of any product, stating that ' $[\mathrm{n}] \mathrm{o}$ prohibitions or restrictions other than duties, taxes or other charges shall be instituted or maintained by any Member...'.

${ }^{270}$ Dawidowicz (2017), 235.

${ }^{271}$ See the US announcement of unilateral coercive measures against Russia, Statement by the President on New Sanctions Related to Russia (2014).

${ }^{272}$ On the US sanctions, see the Russian Ministry of Foreign Affairs, Comment by the Russian Ministry of Foreign Affairs regarding the Continuing Anti-Russian Sanctions of the United States (30 July 2014).

${ }^{273}$ See draft UNSCR S/2014/189 (vetoed).

${ }^{274}$ UNGA Res. 68/262 (2014).

${ }^{275}$ UNGA Res. 71/205 (2016); and UNGA Res. 73/263 (2018).

${ }^{276}$ ARSIWAC (2001), Introductory Commentary to Part Three, Chapter II, para. 2. The legal requirements under these articles have customary status, see Corn Products International Inc. v. Mexico, arbitral award (2008), para. 145.

${ }^{277}$ Articles 49 and 53 ARSIWA.

${ }^{278}$ Article 50 ARSIWA.

${ }^{279}$ Article 51 ARSIWA.
} 
allow it to cease with its unlawful conduct prior to the adoption of countermeasures against it. $^{280}$

If a right to take third-party countermeasures is emerging as a rule under customary law, the question is whether these legal conditions and procedural safeguards limiting the use of countermeasures apply by analogy also to third-party countermeasures. The ILC Drafting Committee initially addressed the matter in 2000 that, considering Crawford's proposal for a regime of 'collective countermeasures', the conditions laid down in what is now Article 49-53 ARSIWA would suffice also for third-party countermeasures, an issue that became moot following the ILC's rejection to include a regime of third-party countermeasures in the final version of the draft. ${ }^{281}$ The current savings clause on thirdparty countermeasures in Article 54 ARSIWA indicates that it does not prejudice the right of any state to take lawful measures against a responsible state, which has been correctly interpreted to refer not to lawful acts under international law (i.e. acts of retorsion), but rather that the use of countermeasures must comply with the general conditions laid down in Articles 49-53 ARSIWA, applicable by analogy also to thirdparty countermeasures. ${ }^{282}$ In the following, this section will briefly consider some of the main issues of the legal conditions governing the use of countermeasures as applicable to third-party countermeasures.

Countermeasures are limited in Article 49 ARSIWA as temporary instruments to induce a wrongdoing state to comply with its obligations. ${ }^{283}$ The objective determination of a prior breach of international law is a 'fundamental prerequisite' to allow recourse to the use of countermeasures. ${ }^{284}$ Practice of third-party countermeasures demonstrates that states have exercised a considerable degree of caution, restricting the use of third-party countermeasures to breaches of communitarian norms that have been documented or established by UN organs such as the General Assembly, the Security Council, the Human Rights Council, or fact-finding missions or independent experts. ${ }^{285}$ Importantly, the only permissible object of countermeasures is to induce the compliance of the

\footnotetext{
${ }^{280}$ Article 52 ARSIWA.

${ }^{281}$ See Chapter 3.2.2, above.

${ }^{282}$ Dawidowicz (2017), 285-286.

${ }^{283}$ ARSIWAC (2001), Article 49, paras. 6-7.

${ }^{284}$ Ibid., para. 2; see also Gabcikovo-Nagymaros Project (1997), para. 83.

${ }^{285}$ See Dawidowicz (2017), 383-385.
} 
wrongdoing state. ${ }^{286}$ Once this objective has been achieved, states must terminate the countermeasure. ${ }^{287}$ The temporary nature of countermeasures is further reinforced in the limitation to the non-performance for the time being of an international obligation, as well as the requirement that countermeasures must be to some extent reversible. ${ }^{288}$ Third-party countermeasures do not have clearly remedial functions, given that the state taking the measures is not directly injured by the breach. In most instances of state practice, third-party countermeasures have been adopted to ensure cessation of the wrongful conduct rather than on the basis of a claim to reparations. ${ }^{289}$ It may be discussed whether third-party countermeasures in fact have political ulterior motives. As has been correctly pointed out in doctrine, political motive and legal justification for state action are analytically distinct. ${ }^{290}$ It is only when third-party countermeasures are incapable of legal justification and only display punitive or ulterior motives that the instrumental aims of such measures must be deemed unlawful. ${ }^{291}$ In practice, there is only limited evidence for the use of punitive third-party countermeasures. ${ }^{292}$

The requirement of that countermeasures must be proportionate in accordance with Article 51 ARSIWA provides that countermeasures must be commensurate with the injury suffered as a consequence of the internationally wrongful act, considering the gravity of the internationally wrongful act and the rights in question. ${ }^{293}$ The requirement of proportionality is understood as the equivalence between the internationally wrongful act and the countermeasure. ${ }^{294}$ The assessment takes into account the injury suffered and the seriousness of the breach in terms of the importance of the interest protected by the obligation breached. ${ }^{295}$ Broadly speaking, the injury caused by the countermeasure must not exceed the injury caused by the initial offence, meaning that the

\footnotetext{
${ }^{286}$ ARSIWAC (2001), Article 49, paras. 1-2.

${ }^{287}$ Article 53 ARSIWA.

${ }^{288}$ Article 49(1)-(2) ARSIWA; see ARSIWAC (2001), Article 49, para. 9.

${ }^{289}$ See Dawidowicz (2017), 297-304, on the scope of remedial rights and claims of reparation by indirectly injured states in the sense of Article 48(2) ARSIWA.

${ }^{290}$ YbkILC (2000), Vol. I, 301, para. 90 (Mr. Brownlie); and Schachter (1982), 59.

${ }^{291}$ See Simma (2007), 380-381, noting that 'self-interested political motives' in part propel the actual adoption of third-party countermeasures and form part of the 'legitimate regime' governing their use. ${ }^{292}$ Dawidowicz (2017), 297.

${ }^{293}$ Article 51 ARSIWA; ARSIWAC (2001), Article 51 ARSIWA, para. 4. See also GabcikovoNagymaros Project (1997), para. 85, where the ICJ adopted a positive definition of proportionality, stating that 'the effects of a countermeasure must be commensurate with the injury suffered, taking into account the rights in question'.

${ }^{294}$ See Cannizzaro (2001), 899.

${ }^{295}$ ARSIWAC (2001), Article 51 ARSIWA, para. 4.
} 
countermeasures adopted are compared against the function of self-redress and if the means chosen are appropriate to achieve that aim. ${ }^{296}$ The assessment of third-party countermeasures would in principle require an assessment of incommensurable interests, significantly reducing the role of reciprocity. ${ }^{297}$ In practice, the flexibility of this requirement is likely to have a moderating effect on the use of third-party countermeasures. However, the nature of third-party countermeasures raises important questions as regards the relationship to other types of measures, whether other thirdparty countermeasures or institutional enforcement action (such as Security Council enforcement under Chapter VII of the UN Charter). In general, it seems desirable to apply a criterion of overall proportionality of these measures, taking into account not only the isolated third-party countermeasure but also the cumulative impact of several measures adopted in response to the same wrongful act. ${ }^{298}$ However, this situation cannot be addressed in the abstract.

The procedural safeguards are the conditions relating to the resort to countermeasures and are found in Article 52 ARSIWA. Before a state takes countermeasures, it must first call upon the responsible state to fulfil its obligations, and notify the responsible state of any decision to take countermeasures and offer to negotiate with that state. ${ }^{299}$ The only exception is urgent countermeasures, as the injured state deems as necessary to preserve its rights. ${ }^{300}$ The purpose of the procedural requirements on countermeasures is to give the responsible state an opportunity to explain its unlawful conduct with the possibility of an immediate return to legality, avoiding countermeasures altogether. ${ }^{301}$ In instances involving third-party countermeasures, the prior demand of redress is fulfilled by way of 'institutional sommation', meaning that the responsible state has been notified by an international institution such as the General Assembly, calling upon it to comply with its obligations under international law. These statements inform decisions of individual states to take third-party countermeasures, as is apparent from references to such

\footnotetext{
${ }^{296}$ Cassese (2005), 302-306.

${ }^{297}$ Dawidowicz (2017), 346-352; Katselli Proukaki (2010), 260-276.

${ }^{298}$ Dawidowicz (2017), 361-364.

${ }^{299}$ Article 52(1) ARSIWA.

${ }^{300}$ Article 52(2) ARSIWA.

${ }^{301}$ ARSIWAC (2001), Article 52 ARSIWA, para. 4.
} 
statements. ${ }^{302}$ As such, the fears of the abusive use of third-party countermeasures given the auto-interpreted nature of such measures have not materialised in practice. ${ }^{303}$

\subsection{Conclusion}

The existence of a right to third-party countermeasures is one of the most controversial topics of the law of state responsibility. The controversy relates to the nature of countermeasures as unilaterally decided and in principle liable to abuse by powerful states, in particular the risk of such states seeking to coerce or intervene in the internal affairs of less powerful states. Community interests have not only had an impact on the traditional understanding of legal obligations as limited to bilateral relationships, but also on the conceptualisation of which actors are (or should be) entitled to invoke state responsibility in the event of a breach of an obligation owed to the international community. Third-party countermeasures were initially seen as a means to operationalize the regime of obligations erga omnes by granting all states the right to take enforcement action in defence of a collective interest. However, members of the ILC as well as states in the Sixth Committee raised strong objections based essentially on the significant risks of abuse and the potentially destabilising effects on treaty relations. It may be recalled that one member of the ILC went as far as refer to the concept as a lex horrenda of international law. The ILC concluded that state practice was too limited to include a right to third-party countermeasures in the final version of the draft Articles, eventually adopting an ambiguous savings clause in Article 54 ARSIWA. It is clear that Article 54 ARSIWA neither endorses nor precludes that a right to third-party to third-party countermeasures may arise as a result of the formation of customary international law. Several recent studies of state practice indicate that this may be the case. Given the obscurity of practice, it is also possible that the actual instances of third-party countermeasures are greater than the ones identified.

It is clear that the instances of state practice greatly exceed those identified by the ILC in 2001. Although the instances discussed above are not sufficient to draw any

\footnotetext{
${ }^{302}$ IDI Resolution (2005), requiring that a breach must be 'widely acknowledged' before a state can adopt third-party countermeasures.

${ }^{303}$ Dawidowicz (2017) 367-379.
} 
conclusions on whether practice is sufficiently widespread or representative, it has been correctly observed that a very significant number of non-Western states in Eastern Europe, the Middle East, Asia and Africa have made significant contributions to practice by either adopting or expressing support for third-party countermeasures, which is evidenced to some extent in recent practice with regard to Libya and Syria. Practice can be described as relatively consistent as it is taken in response to major international crises involving breaches of communitarian norms, most notably in response to violations of human rights and humanitarian law. The common denominator of state practice is that the rationale for the measures is based on a notion of humanitarian necessity. The situation is therefore not only of concern to the international community, but also requires action in response to breaches that are not adequately addressed by institutional enforcement mechanisms. However, the Security Council's increasing activity in this area means that there is a risk of overlapping enforcement regimes in this area, or at the very least an interaction between the law of state responsibility and the law of collective security. In conclusion, state practice strongly suggests that the right to third-party countermeasures is emerging under customary international law.

\section{The Relationship between Third-Party}

\section{Countermeasures and the Security Council's}

\section{Chapter VII Enforcement Powers}

\subsection{Introduction}

The now substantial body of state practice suggests that the right to third-party countermeasures is emerging under customary international law, as a response to breaches of obligations erga omnes. ${ }^{304}$ At the same time, breaches of fundamental community obligations have increasingly been subject to collective enforcement measures taken by the Security Council under Chapter VII of the UN Charter. ${ }^{305}$ As both the law of state responsibility and the law of collective security now provide for

\footnotetext{
${ }^{304}$ See Chapters 3.2.2 and 3.3, above.

${ }^{305}$ See Chapter 2.3.2, above.
} 
the legal consequences resulting from the breach of obligations erga omnes, there is a link between the two at least in practice. The coexistence of enforcement action, taken by individual states through third-party countermeasures, and collective or institutionalised responses, in the form of Security Council enforcement under Chapter VII of the UN Charter, raises the complex question of whether reactions to breaches of fundamental obligations should take place within a unilateral or institutional framework. ${ }^{306}$ So far, the relationship between third-party countermeasures and Security Council enforcement measures remains unclear, despite the significant developments in state practice. ${ }^{307}$ In this context, it has been suggested that once the Security Council has decided on mandatory sanctions under Chapter VII of the UN Charter, states 'transform into agents' for the execution of these sanctions to implement without undermining their effective application. ${ }^{308}$ Other commentators have similarly argued that the triggering of Security Council action under Chapter VII of the UN Charter entails an implied obligation to suspend any third-party countermeasures already adopted, insofar they are different or incompatible with UN sanctions, or at least to adapt them to ensure harmonization with institutional action. ${ }^{309}$

This chapter will examine the relationship between third-party countermeasures in the law of state responsibility and the Security Council's enforcement powers under Chapter VII of the UN Charter. It will begin by examining whether there are limitations on the use of third-party countermeasures under ARSIWA or the UN Charter, specifically in relation to parallel Security Council engagement in a situation. Then, it will consider two instances of state practice in which third-party countermeasures and Security Council enforcement measures were taken concurrently to illustrate the application of the theoretical framework in practice.

\footnotetext{
${ }^{306}$ Gowlland-Debbas (2010), 115-117.

${ }^{307}$ See Gowlland-Debbas (2010), 122, 124; Sicilianos (2010), 1140-1142; Crawford (2013), 709;

Palchetti (2014) 1234-1236; and HRC Report by Special Rapporteur Jazairy (2015), 17-18.

${ }^{308}$ Sicilianos (2010), 1138-1142.

${ }^{309}$ Frowein (1994), 370-371; Sicilianos (2010), 1142; Crawford (2013), 709; Palchetti, (2014), $1234-$ 1236; Dupont (2012), 332-334; HRC Report by Special Rapporteur Jazairy (2015), 17-18.
} 


\subsection{The Relationship between ARSIWA and the UN Charter}

\subsubsection{Primacy of Obligations under the UN Charter}

The relationship between the law of state responsibility and the UN Charter is expressed in Article 59 ARSIWA, which provides that the draft Articles are 'without prejudice to the UN Charter'. ${ }^{310}$ The Commentary provides little clarification beyond the reference to the supremacy clause in Article 103 of the UN Charter and that in the event of conflict with a treaty obligation Charter obligations prevail. ${ }^{311}$ In principle, the meaning of Article 59 ARSIWA is that the draft Articles are without prejudice to the UN Charter and must be interpreted in conformity with it, i.e. cannot affect the obligations arising under the latter. ${ }^{312}$

The exclusion of the UN Charter from the scope of ARSIWA reflects a long-standing debate in the ILC on the place of the UN Charter in the law of state responsibility and in the draft Articles. ${ }^{313}$ In proposals relating to the regime of differentiated responsibility for international crimes and international delicts, respectively, Charter-based mechanisms of collective security were viewed as an institutionalised response to international crimes. It may be recalled that 'crimes' of this nature consisted of breaches of communitarian norms of concern to the international community as a whole. ${ }^{314}$ Draft Article 39 [1996], regulating the relationship between the law of state responsibility and the law of collective security, provided that '[t]he legal consequences of an internationally wrongful act of a State set out in the provisions of this Part are subject, as appropriate, to the provisions and procedures of the Charter of the United Nations relating to the maintenance of international peace and security'. ${ }^{315}$ In effect, draft Article 39 [1996] subordinated the draft Articles as a whole to the UN Charter, considering that the latter was better placed to respond to internationally wrongful acts

\footnotetext{
${ }^{310}$ Article 59 ARSIWA; ARSIWAC (2001), Article 59 paras. 1-2.

311 ARSIWAC (2001), Article 59, para. 1.

312 Ibid., para. 2.

${ }^{313}$ Gowlland-Debbas (2010), 120-122.

${ }^{314}$ See Chapters 2.2.3 and 3.2.2, above.

315 Arangio-Ruiz, Fourth Report on State Responsibility (1992), paras. 260-266; and Arangio-Ruiz (2000), 747.
} 
in the form of state crimes. ${ }^{316}$ The distinction between international crimes and delicts was eventually dropped following the recognition that the draft Articles could not modify or condition the UN Charter, and that the UN Charter in principle already provided for a response to such acts under Chapter VII. ${ }^{317}$ However, the principle underlying draft Article 39 [1996] had general support of governments and was eventually replaced by Article 59 ARSIWA. ${ }^{318}$ The preference for institutional mechanisms to deal with breaches of communitarian norms, rather than under the law of state responsibility, illustrates the nature of the UN Charter as the constitution of the international community. ${ }^{319}$

The current Article 59 ARSIWA expresses the hierarchical superiority of the UN Charter over other treaty-based obligations of international law. ${ }^{320}$ It serves to resolve potential conflicts between obligations arising under ARSIWA and the UN Charter, and does not as such aim to subsume the draft Articles to the UN Charter. ${ }^{321}$ It is also a situation distinct from self-contained regimes that are lex specialis in relation to the law of state responsibility. ${ }^{322}$ According to Article 103 of the UN Charter, which clarifies the relationship of the Charter in relation to other obligations arising under conventional international law, provides that '[i]n the event of a conflict between the obligations of the Members of the United Nations under the Charter and their obligations under any other international agreement, their obligations under the present Charter shall prevail' ${ }^{323}$ The reference to 'any other international agreement' is a direct reference to the Charter's pre-eminence over other obligations arising under conventional international law, i.e. obligations arising under other international treaties. ${ }^{324}$ This provision extends also to the derivative obligations of the UN Charter, such as the mandatory decisions of the Security Council under Chapter VII of the UN Charter,

\footnotetext{
${ }^{316}$ Riphagen, Third Report on State Responsibility (1982) para. 48; and ILC, Report of the Drafting Committee: State Responsibility - Draft Articles Provisionally Adopted by the Drafting Committee on Second Reading (1996), draft Article 39. For a further commentary on draft Article 39 [1996], see Gowlland-Debbas (2010), 118-120.

${ }^{317}$ Crawford, First Report on State Responsibility (1998), paras. 1, 3, 8.

${ }^{318}$ Crawford, First Report on State Responsibility (1998) paras. 1, 3.

${ }^{319}$ See Chapter 2.3, above.

${ }^{320}$ Gowlland-Debbas (2010), 115-117.

${ }^{321}$ See ARSIWAC (2001), Article 59, paras. 1-2.

322 The situation in Article 59 ARSIWA is therefore distinct from the regime of lex specialis in Article 55 ARSIWA, which expresses the more limited legal relationship of self-contained regimes. ARSIWAC (2001), Article 55 ARSIWA, paras. 1-2.

${ }^{323}$ Article 103 of the UN Charter.

${ }^{324}$ Simma (2012), Commentary to Article 103, paras. 1-3 and 66-69.
} 
which are binding by virtue of Article $25 .{ }^{325}$ It is currently unclear to what extent this hierarchy operates also in relation to obligations arising under customary international law, such as the law of state responsibility. ${ }^{326}$ Article 103 of the UN Charter does not exclude the possibility of later developments in the law. In this context, those in favour of a 'constitutional' vision of the UN Charter ${ }^{327}$ have argued that Article 103 must be interpreted to extend also to obligations arising under customary international law. ${ }^{328}$ In the practice of the Security Council, the general understanding appears to be that Security Council resolutions override conflicting customary international law, meaning that it would be inconsistent if those effects did not extend to the Charter itself as the Security Council is a product of the Charter. ${ }^{329}$

The application of Article 59 ARSIWA, read in combination with the supremacy clause in Article 103 of the UN Charter, is not entirely clear in relation to the use of third-party countermeasures. While it is possible under these articles that Security Council decisions override conflicting obligations arising under customary international law, this does not mean that the operation of the law of state responsibility is displaced in its entirety in situations where the Security Council is also taking action. Article 59 ARSIWA should not be understood as a limitation on the right to take countermeasures, but rather that the rules of state responsibility continue to apply to states in carrying out their obligations arising under the UN Charter to the extent that there are no express derogations from them and where they do not affect obligations of states arising under the Charter. ${ }^{330}$ The priority established in Article 59 ARSIWA therefore does not rule out the operation of the law of state responsibility or the use of third-party countermeasures in situations where the Security Council is either actively seized with a situation or is taking enforcement action. ${ }^{331}$ It is uncertain whether the use of third-party countermeasures with a similar objective to sanctions adopted by the Security Council would actually come into conflict with the latter.

\footnotetext{
${ }^{325}$ Ibid., para. 2; see also Lockerbie (1998).

${ }^{326}$ White and Abass (2003), 518.

${ }^{327}$ See Chapter 2.3.1, above.

${ }^{328}$ ILC, Report on the Fragmentation of International Law (2006), para. 344.

${ }^{329}$ Ibid., para. 345.

${ }^{330}$ Gowlland-Debbas (2010), 120-122, 138.

${ }^{331}$ Calamita (2009), 1437-1441.
} 


\subsubsection{Implied Limitations under the UN Charter}

The controversial nature of the concept of third-party countermeasures has led to debate as to whether the UN Charter could act to displace the law of state responsibility with regard to the use of third-party countermeasures. There are two main arguments in this regard. The first argument is an analogy to the right of self-defence under Article 51 of the UN Charter, according to which states' right to take third-party countermeasures in the collective interest would be extinguished once the Security Council has taken enforcement measures under Chapter VII of the UN Charter with regard to the same situation. The second argument is based on an interpretation of the terms and structure of the UN Charter, as well as its general spirit, that would imply an obligation of states to cease with third-party countermeasures once the Security Council takes measures in response to the same situation.

The first argument of the analogy to the right of self-defence is based on an interpretation of the relationship between individual states and the Security Council under Article 51 of the UN Charter. ${ }^{332}$ According to Article 51 of the UN Charter, states are entitled to resort to the use of force in order to repel an incoming armed attack. The right to use force in self-defence is extinguished once the Security Council has taken enforcement measures in accordance with Chapter VII of the UN Charter. ${ }^{333}$ This function of the Security Council is a reflection of the monopoly on the use of force afforded to it under the UN Charter, a clear reflection of its privileged position as primarily responsible for the maintenance of international peace and security under Article 24 of the UN Charter. ${ }^{334}$ By analogy to Article 51, and the relationship expressed thereunder, the right of states to take third-party countermeasures would similarly be extinguished once the Security Council has decided on enforcement measures under Chapter VII of the UN Charter. ${ }^{335}$ In debates in the Sixth Committee during the drafting process of ARSIWA, Morocco clarified this point, suggesting that 'by analogy to the right of self-defence, a State should cease its own countermeasures once the Security Council [has] ordered collective economic sanctions', presumably in

\footnotetext{
${ }^{332}$ See Frowein (1994), 370-371.

${ }^{333}$ Generally on the scope of self-defence under Article 51 of the UN Charter, see Gray (2018), 134-170.

${ }^{334}$ Gray (2018), 132-134; and generally, Sarooshi (1999), 3-16.

${ }^{335}$ Frowein (1994), 370-371.
} 
relation to non-forcible measures taken under Article 41 of the UN Charter. ${ }^{336}$ It may be recalled from the previous section that the savings clause in Article 59 ARSIWA does not offer much in the way of clarity as to the relationship between third-party countermeasures and collective security, and therefore it is not clear whether the restrictions relating to the monopoly on the use of force apply by analogy also to the use of third-party countermeasures. ${ }^{337}$ The right to self-defence under Article 51 of the UN Charter addresses a unique exception in international law to the otherwise complete prohibition on the use of force in Article 2(4) of the UN Charter. By contrast, there is no corresponding prohibition on the rights of member states to take countermeasures once the Security Council has taken enforcement measures, whether they are forcible or nonforcible. ${ }^{338}$ The lack of textual parallels between the framework on the use of force and the right of states to take countermeasures strongly suggests that the analogy to selfdefence under Article 51 of the UN Charter is inappropriate.

The second argument is based on the existence of implied limitations on the use of third-party countermeasures under the UN Charter. ${ }^{339}$ It has been argued that '[the] recourse to the measures provided for in Chapter VII of the Charter was the first essential limitation on the unilateral use of countermeasures. If the Security Council has decided on sanctions, in accordance with Articles 41 and 42 of the UN Charter, it was hardly likely that States would take no notice of them and continue to carry out measures of their own, just as individual or collective self-defence was allowed in the event of aggression only, according to Article 51... until the Security Council has taken measures necessary to maintain international peace and security. If the Security Council had decided on measures within the meaning of Articles 41 and 42, States were no longer free to decide as they wished on countermeasures of their own' ${ }^{340}$ This argument appears to rest on the perceived constitutional character of the UN Charter and on the primacy of the Security Council in the system of collective security. ${ }^{341}$ In particular,

\footnotetext{
${ }^{336}$ See the statements by Morocco (UN Doc. A/C.6/56/SR.11, 7, 9, para. 39); see also Greece (UN Doc. A/C.6/55/SR.17, 14, para. 85); and the Netherlands (A/CN.4/515, 87).

337 See Chapter 4.2.1, above.

${ }^{338}$ Calamita (2009), 1437-1441.

${ }^{339}$ See Frowein (1994), 370-371; Sicilianos (2010), 1142; Crawford (2013), 709; and Dupont (2012), 332-334; Palchetti, (2014), 1234-1236; UN HRC Report by Special Rapporteur Jazairy (2015), 17-18; and YbkILC (2001), Vol. I, 40, para. 41 (Mr. Economides).

${ }^{340}$ YbkILC (1992), Vol. I, 144 (comments made by Mr. Pellet).

${ }^{341}$ Dupont (2012), 333, referencing Sarooshi, (1999), 5-6.
} 
unilaterally decided third-party countermeasures would have the effect of undermining the central role and powers of the Security Council and disrupting the delicate institutional balance of the UN Charter. ${ }^{342}$ In order to preserve the coherence of the international legal system, unilateral enforcement mechanisms such as the use of thirdparty countermeasures must be limited and subsumed to collective mechanisms. The triggering of Security Council enforcement action within the institutional framework of Chapter VII of the UN Charter would end the right to to take third-party countermeasures or to take unilateral enforcement measures. ${ }^{343}$ In general, implied limitations on the rights of states under the UN Charter must be interpreted restrictively and treated with utmost caution. ${ }^{344}$ This was explained by the ICJ in the Certain Expenses of the United Nations advisory opinion, considering that '[ $\mathrm{t}$ ] hese purposes [of the UN Charter] are broad indeed, but neither they nor the powers conferred to effectuate them are unlimited. Save as they have entrusted the Organization with the attainment of these common ends, the Member States retain their freedom of action'. ${ }^{345}$ There is nothing in the UN Charter, whether taken as a whole or those provisions addressing the role of the Security Council in particular, to suggest that the Security Council's exercise of powers under Articles 41 or 42 of the UN Charter acts additionally to displace the application of the law of state responsibility. ${ }^{346}$ The argument of implied limitations appears to be based in the view of the UN Charter as a constitutional argument for the international community, but does not seem to have a clear legal support. Therefore, this argument also seems inappropriate.

\subsubsection{The Security Council as an Institutional Safeguard}

The role of the Security Council as primarily responsible for the maintenance of international peace and security has led to discussion as to whether the Security Council within its powers can act as a form of institutional safeguard to limit the use of thirdparty countermeasures. ${ }^{347}$ It may be recalled that there was strong support from

\footnotetext{
${ }^{342}$ Sicilianos (2010), 1142.

${ }^{343}$ Sicilianos (2010), 1138; and Dupont (2012), 333.

${ }^{344}$ Calamita (2009), 1439.

${ }^{345}$ Certain Expenses of the United Nations (Article 17, para 2, of the Charter), ICJ (1962), 168.

${ }^{346}$ Wellens (2003), 15, 50, referencing Gaja (1993), 28.

${ }^{347}$ Dawidowicz (2006), 346, 415-417, with further references.
} 
members of the ILC as well as states in the Sixth Committee to formally include such a role for the Security Council within the scope of ARSIWA. ${ }^{348}$

The Security Council has broad powers under Chapter VII of the UN Charter to decide on legally binding resolutions. ${ }^{349}$ In theory, these powers extend to the possibility of decisions that either prohibit or limit the use of third-party countermeasures by individual states, in situations where the Security Council determines that unilateral countermeasures would be a hindrance to collective efforts. ${ }^{350}$ While this is a possibility in theory, the Security Council has yet to exercise these powers, even in situations where third-party countermeasures have been taken concurrently with Security Council enforcement measures. ${ }^{351}$ In the majority of instances of state practice, third-party countermeasures have been adopted in the absence of intervention of the Security Council; even where the Council has been actively seized with a matter or taken enforcement measures. ${ }^{352}$ As neither ARSIWA nor the UN Charter supports any formal role of the Security Council as an institutional safeguard, it can be concluded that the constitutionalisation of the enforcement function of the UN Charter in providing a collective response to breaches of international law has not been matched by a corresponding development of institutional safeguards against the abuse of third-party countermeasures. ${ }^{353}$

\subsection{Case Studies}

\subsubsection{Introduction}

There are several instances of state practice in which states have taken third-party countermeasures in situations where the Security Council is actively seized with a matter but has decided not to impose sanctions under Chapter VII of the UN Charter, or where the Security Council has decided to impose sanctions but the state's third-party

\footnotetext{
${ }^{348}$ See Chapter 3.2.2, above.

${ }^{349}$ Article 25 of the UN Charter.

${ }^{350}$ See Hillgruber (2006), 287-288; Dawidowicz (2017), 261-262; and Tams (2005), 264-268.

${ }^{351}$ Dawidowicz (2017), 262.

${ }^{352}$ Tams (2005), 236.

${ }^{353}$ Cf. Simma (1994), 248-249.
} 
countermeasures go beyond or are different in scope from what has been authorized by the Security Council. ${ }^{354}$

The instances of practice include the unilateral coercive measures adopted against North Korea and China for the invasion of South Korea in 1950, in which the Security Council had become seized with the matter but not decided to impose sanctions; ${ }^{355}$ against Argentina for its invasion of the Falkland Islands (Islas Malvinas) in 1982, in which the Security Council had become seized with the matter but decided not to impose sanctions; ${ }^{356}$ against South Africa in response to its illegal regime of apartheid in 1985 , in which the scope of measures taken by the US exceeded the scope of those already imposed by the Security Council, ${ }^{357}$ against Burundi in response to political repression in 1996, in which the Security Council had become seized with the matter but decided not to impose sanctions; ${ }^{358}$ against the Former Republic of Yugoslavia in response to grave violations of human rights committed in Kosovo, in which European Community member states' sanctions exceeded the scope of sanctions already imposed by the Security Council; ${ }^{359}$ and against North Korea for its test launch of missiles in the Sea of Japan in 2006, after which the Security Council decided to adopt limited sanctions. ${ }^{360}$ In these cases, the relative absence of protests or other action from the Security Council suggest that there is no incompatibility in practice between third-party countermeasures and the Security Council's scope of action under Chapter VII of the UN Charter.

This section will focus on two case studies in which third-party countermeasures have been adopted concurrently with Security Council enforcement measures under Chapter VII of the UN Charter: measures taken by Western states against Sudan (1997-present), and measures taken by miscellaneous states against Libya (2011-present). The measures adopted against Sudan and Libya were taken in response to serious violations of human rights and humanitarian law, and were taken either prior to or concurrently with measures decided by the Security Council. The case studies serve to illustrate the

\footnotetext{
${ }^{354}$ For an overview, see Calamita (2009), 1439-1440.

${ }^{355}$ Katselli Proukaki (2010), 114; and Dawidowicz (2006), 351.

${ }^{356}$ Katselli Proukaki (2010), 114; and Dawidowicz (2006), 351.

${ }^{357}$ Dawidowicz (2017), 154-159; Katselli Proukaki (2010), 165-177; Tams (2005), 217-219.

${ }^{358}$ Dawidowicz (2017), 168-176, Katselli Proukaki (2010), 190; Tams (2005), 221-223.

${ }^{359}$ Dawidowicz (2017), 181-193; Katselli Proukaki (2010); 191-196; Tams (2005), 223-224.

${ }^{360}$ Calamita (2009), 1440.
} 
similarities and differences between measures taken at the individual and institutional levels.

Each case study is introduced with a background to the situation, including the alleged breach of a communitarian norm and an overview of the enforcement measures taken at the institutional and individual levels. Then, an overview is given of Security Council responses under Chapter VII of the UN Charter, followed by an overview of unilateral coercive measures, taken by individual states, and whether they might be understood as third-party countermeasures. The final section will provide a brief analysis and some concluding remarks.

\subsubsection{Sudan (1997-present)}

\subsubsection{Background}

The protracted civil war in Sudan between 1983 and 2005 has been described as one of the bloodiest conflicts in recent history, causing significant civilian deaths and internal displacement. ${ }^{361}$ In the 1990 s, the UN General Assembly adopted several resolutions, expressing its deep concern at the continuing and serious violations of human rights committed in the country, including summary executions, arbitrary detentions, torture and forced displacement, calling on Sudan to cease with all human rights violations and comply with its obligations under international human rights and humanitarian law. ${ }^{362}$ The Commission on Human Rights (preceding the UN Human Rights Council) also condemned the situation in a series of resolutions adopted between 1993 and $2005 .{ }^{363}$ At this stage, a number of enforcement measures were adopted against Sudan. In response to the human rights situation in Sudan, the EU imposed unilateral coercive measures against Sudan in 1994, in the form of an arms embargo. ${ }^{364}$ The Security Council did not take enforcement action in response to the situation to the country until 1996, imposing

\footnotetext{
${ }^{361}$ OHCHR, Second Periodic Report of the United Nations High Commissioner for Human Rights on the Human Rights Situation in Sudan (2006), 5-9.

${ }^{362}$ On the human rights situation in Sudan, UNGA Res. 47/142 (1992); UNGA Res. 48/147 (1993); UNGA Res. 49/198 (1995); UNGA Res. 50/197 (1996); UNGA Res. 51/112 (1997).

${ }^{363}$ See UN Commission on Human Rights resolutions 1993/69 (1993); 1994/79 (1994); 1995/77 (1995); 1996/73 (1996); 1997/59 (1997); 1998/67 (1998); 1999/15 (1999); 2000/27 (2000); 2005/82 (2005).

${ }^{364}$ Council Decision 94/165/CFSP (1994).
} 
sanctions in response to Sudan's alleged support for international terrorism by limiting diplomatic relations with Sudan and imposing travel bans on members or officials of the Sudanese government. ${ }^{365}$ The United States, considering the the Security Council enforcement regime was insufficient, adopted in 1997 unilateral coercive measures against Sudan in the form of a trade embargo and freezing of assets belonging to members of the Sudanese government. ${ }^{366}$ While the Security Council sanctions regime was lifted in 2001, the measures adopted by the EU and the United States remained in place since. $^{367}$

Following the end of the civil war in Sudan, the situation in the Darfur region of worsened and led to a humanitarian crisis unfolded, involving serious violations of human rights and humanitarian law. ${ }^{368}$ The Security Council took action in 2005, deciding on enforcement measures under Chapter VII of the UN Charter in the form of an arms embargo, travel bans and asset freezes on designated individuals, as well as a referral of the situation to the ICC. ${ }^{369}$ Following a declaration before the General Assembly that the situation in Darfur amounted to genocide, the United States broadened the rationale for the measures it had initially adopted in $1997 .{ }^{370}$ The EU took similar action, extending the arms embargo adopted in 1994 to include also technical and financial assistance related to arms supplies. ${ }^{371}$ These measures, together with Security Council-mandated sanctions, remained in place concurrently.

\subsubsection{Security Council Enforcement Measures}

The measures taken by the Security Council can be understood in two phases. The first phase of the Security Council's response included sanctions taken in response to Sudan's alleged support and backing of international terrorism, following a request by

\footnotetext{
${ }^{365}$ UNSCR 1054 (1996).

${ }^{366}$ The US, Executive Order 13067, Blocking Sudanese Government Property and Prohibiting Transactions with Sudan (3 November 1997).

${ }^{367}$ On the termination of the Security Council sanctions regime, see UNSCR 1372 (2001).

${ }^{368}$ OHCHR, Fourth Periodic Report of the United Nations High Commissioner for Human Rights on the Situation of Human Rights in Sudan, Deepening Crisis in Darfur Two Months After the Darfur Peace Agreement: An Assessment (2005), 4-5.

${ }^{369}$ UNSCR 1591 (2005); and UNSC Res. 2206 (2015) concerning South Sudan.

${ }^{370}$ UNGA, Statement of President Bush, the United States (21 September 2004)

${ }^{371}$ Common Position 2004/31/CFSP, Council Regulation (EC) No 31/2004, Common Position 2004/510/CFSP; see also Common Position 2005/411/CFSP, Council Regulation (EC) No 838/2005.
} 
Ethiopia to the Security Council for enforcement action in $1996 .{ }^{372}$ Following the termination of the sanctions regime imposed in this first phase in 2001, the Security adopted in 2005 a broader regime of sanctions based on a human rights-oriented rationale in response to the worsening situation in Darfur. ${ }^{373}$

Following the assassination attempt of the then incumbent Egyptian president Mubarak in Addis Ababa, Ethiopia, in 1995, Ethiopia submitted a request to the Security Council for enforcement action, claiming that Sudan had acted in contravention of the principles of the non-use of force and non-intervention. ${ }^{374}$ On 31 January 1996, the Security Council adopted a resolution whereby it 'strongly [deplored] the flagrant violation of the sovereignty and integrity of Ethiopia and the attempt to disturb the peace and security of Ethiopia and the region as a whole', demanding that Sudan comply with the request for extradition and desist from assisting, supporting and facilitating terrorist activities. ${ }^{375}$ Following the non-compliance of Sudan, the Security Council adopted a further resolution under Chapter VII of the UN Charter, imposing non-forcible sanctions under Article 41 including limitations on diplomatic relations with Sudan and travel bans applicable to members and officials of the Sudanese government. ${ }^{376}$ The Security Council adopted an additional resolution on 16 August 1996, deciding to impose additional sanctions under Chapter VII of the UN Charter in case of continued noncompliance. However, the proposed aviation embargo under this resolution was never actually implemented. ${ }^{377}$ This initial sanctions regime against Sudan was terminated in 2001 following improvements of the situation in the country. ${ }^{378}$

In response to the worsening situation in Sudan towards the end of the civil war, the Security Council took enforcement action, acting under Chapter VII of the UN Charter. ${ }^{379}$ In a resolution adopted on 29 March 2005, the Security Council expressed 'its utmost concern over the dire consequences of the prolonged conflict for the civilian population in the Darfur region as well as throughout Sudan, in particular the increase in

\footnotetext{
${ }^{372}$ UNSCR 1054 (1996).

${ }^{373}$ UNSCR 1591 (2005)

${ }^{374}$ UNSCR 1070 (1996), PP3.

${ }^{375}$ UNSCR 1044 (1996).

${ }^{376}$ UNSCR 1054 (1996).

${ }^{377}$ UNSCR 1070 (1996).

${ }^{378}$ UNSCR 1372 (2001).

${ }^{379}$ UNSCR 1591 (2005)
} 
the number of refugees and internally displaced persons', while also condemning 'continued violations of human rights and international humanitarian law in the Darfur region'. ${ }^{380}$ In accordance with Article 41 of the UN Charter, the Security Council imposed non-forcible enforcement measures, including an arms embargo, travel bans and asset freezes on designated individuals, as well a referral of the situation to the ICC. ${ }^{381}$ In 2015 , the Security Council adopted a further resolution to regulate separately the sanctions regime for South Sudan following its independence from Sudan in $2011^{382}$

\subsubsection{Third-Party Countermeasures}

The measures taken by individual states in response to the situation in Sudan comprise of sanctions initially adopted by the EU in 1994 in the form of an arms embargo, ${ }^{383}$ and by the US in 1997 in the form of a trade embargo and the freezing of assets belonging to members and officials of the Sudanese government. ${ }^{384}$

On 15 March 1994, prior to any Security Council enforcement with regard to Sudan, the EU imposed unilateral coercive measures against Sudan. These measures were in the form of an embargo on arms, munitions and military equipment to Sudan, in response to the human rights situation in the country. ${ }^{385}$ As Sudan was not a party of either the GATT or WTO at the time, these measures are likely best understood as acts of retorsion, i.e. lawful measures taken in response to a prior breach of international law. ${ }^{386}$ On 3 November 1997, following the adoption by the Security Council of enforcement measures in 1996, ${ }^{387}$ the US adopted unilateral coercive measures against Sudan in the form of a trade embargo and the freezing of assets belonging to members or officials of the Sudanese government. ${ }^{388}$ The rationale for adopting these measures was Sudan's

\footnotetext{
${ }^{380}$ UNSCR 1591 (2005)

${ }^{381}$ UNSCR 1591 (2005)

382 UNSCR 2206 (2015)

${ }^{383}$ Council Decision 94/165/CFSP (1994).

384 The US, Executive Order 13067: Blocking Sudanese Government Property and Prohibiting Transactions with Sudan (3 November 1997).

${ }^{385}$ Council Decision 94/165/CFSP (1994).

${ }^{386}$ As of May 2019, Sudan is in the process of acceding to the WTO.

${ }^{387}$ UNSC Res. 1044 (1996) and 1054 (1996).

388 The US, Executive Order 13067: Blocking Sudanese Government Property and Prohibiting Transactions with Sudan (3 November 1997).
} 
'continued support for international terrorism, on going efforts to destabilise neighbouring governments, and the prevalence of human rights violations, including slavery and the denial of religious freedom', as well as cross-border attacks in the region in contravention of the principles of the non-use of force and non-intervention under the UN and OAU Charters. ${ }^{389}$ As Sudan was not a member of the GATT or WTO at the time, these measures are best understood as acts of retorsion, similarly to the EU trade embargo adopted in 1994. The freezing of assets would require justification under general international law as these measures were taken in contravention of the obligations of the US under customary international law to protect foreign investments. ${ }^{390}$ As the US was not directly injured by the violations of international law committed in Sudan, the asset freeze can be analysed as a third-party countermeasure in response of a breach of obligations erga omnes.

In response to the worsening situation in Darfur, the US declared on 21 September 2004 that the 'horrible crimes in the Darfur region of Sudan' amounted to genocide for which Sudan was responsible (i.e. a breach of a peremptory norm of international law), effectively broadening the rationale for the measures already adopted in $1997 .{ }^{391}$ The EU also strengthened the unilateral coercive measures already in place against Sudan by extending the arms embargo it had initially adopted in 1994 to include also technical and financial assistance related to arms supplies and to exempt any supplies to UN, EU and AU institutions in Sudan and demining operations. ${ }^{392}$ The EU implemented the Security Council sanctions imposed against Sudan in 2005 by merging them with the existing EU arms embargo on Sudan, also amending the arms embargo to allow assistance and supplies in support of the Comprehensive Peace Agreement between the Sudanese government and the Sudan People's Liberation Movement. ${ }^{393}$ The measures imposed by the EU and US have remained in place since they were first adopted in 1994

\footnotetext{
${ }^{389}$ The US, Executive Order 13067: Blocking Sudanese Government Property and Prohibiting Transactions with Sudan (3 November 1997).

${ }^{390}$ See Criddle (2013) 590-593.

${ }^{391}$ UNGA, Statement of President Bush, the United States (21 September 2004).

${ }^{392}$ Common Position 2004/31/CFSP (2004); Council Regulation (EC) No 31/2004 (2004); and Common Position 2004/510/CFSP (2004).

${ }^{393}$ Common Position 2005/411/CFSP (2004); Council Regulation (EC) No 838/2005 (2005).
} 
and 1997, and have been strengthened at least once to respond to the situation in Sudan (and South Sudan following its independence from Sudan). ${ }^{394}$

\subsubsection{Analysis}

It is clear on the basis of the chronology of events in Sudan that the unilateral coercive measures were taken both prior to and subsequently concurrently with Security Council enforcement action. The EU arms embargo, adopted in 1994, was imposed prior to the first Security Council resolutions on Sudan adopted in 1996 (and then terminated in 2001). ${ }^{395}$ In 1997, the US adopted the most comprehensive measures against Sudan, in the form of a trade embargo and asset freezes against members or officials of the Sudanese government. Following the termination of the Security Council sanctions regime in $2001,{ }^{396}$ the measures imposed by the EU and the US remained in place. In 2005 when the Security Council adopted a new sanctions regime with respect to the situation in Sudan, ${ }^{397}$ both of these unilateral sanctions regimes operated in parallel with the Security Council measures. As was noted above, the EU and the US actually strengthened measures already in place with reference to violations of international law amounting to genocide in Sudan.

The international response to the situation in Sudan illustrates a clear difference in the scope and rationale for the measures adopted at the unilateral and institutional levels. In the first resolution adopted by the Security Council, the measures were not directly intended as a collective response to serious breaches of human rights and humanitarian law committed during the civil war in Sudan, but rather as a response to Sudan's alleged support for international terrorism. This corresponds to the limited mandate of the Security Council under Article 24 of the UN Charter to take measures for the maintenance of international peace and security. ${ }^{398}$ The unilateral coercive measures

\footnotetext{
${ }^{394}$ Note, however, that the US temporarily lifted three significant components of its sanctions regime against Sudan in January 2017. The EU made amendments in 2011 to its arms embargo to cover also the newly independent South Sudan, see Council Decision (EU) 2011/423/CFSP (2011). From 10 July 2014 and onwards, the measures concerning South Sudan are regulated by a separate restrictive measures regime.

${ }^{395}$ UNSCR 1044 (1996) and UNSCR 1054 (1996).

${ }^{396}$ UNSCR 1372 (2001).

${ }^{397}$ UNSCR 1591 (2005).

${ }^{398}$ See Chapter 2.3.2, above.
} 
adopted initially by the EU and the US operated on a much broader rationale, explicitly referring to serious violations of human rights and humanitarian law. It is necessary to restate that only the asset freezes imposed by the US that might constitute third-party countermeasures, given that Sudan was not party to either the GATT or the WTO at the time. The on going character of the violations of human rights and humanitarian law in Sudan led to that these regimes were maintained in force even after the Security Council had terminated its limited sanctions regime in $2001 .^{399}$ This further illustrates not only the difference in the scope of measures adopted at the unilateral and institutional levels, but also the limitations in the Security Council's mandate in providing a collective response to such breaches. The subsequent sanctions regime imposed by the Security Council in 2005 clearly had a much broader rationale that corresponds to the measures already adopted at the unilateral level.

\subsubsection{Libya (2011-present)}

\subsubsection{Background}

There is a long history of government control, repression of civil society and other violations of human rights in Libya. In Libya, there were significant restrictions on the freedom of assembly and expression, including the criminalisation of political dissent. ${ }^{400}$ The Libyan uprising, in the context of the Arab Spring protests, began on 17 February 2011 after security forces fired on protestors demonstrating against the regime. The events marked the beginning of a series of similar incidents across Libya in response to which the Libyan government resorted to excessive use of force in the repression of protestors. In particular, the Libyan government used artillery, helicopter gunships, and snipers to attack protesters, as well as foreign mercenaries. Groups opposing the government subsequently established an interim governing body, the National Transnational Council, on 27 February 2011 to act as an authority in rebelcontrolled areas. The situation soon escalated into a full-scale civil war in the

\footnotetext{
${ }^{399}$ UNSCR 1372 (2001).

${ }^{400}$ HRC, Report of the International Commission of Inquiry on Libya (2012), paras. 10-14; and Report of the Working Group on the Universal Periodic Review: Libyan Arab Jamahiriya (2011); and Human Rights Watch, World Report 2011: Libya (2011); and Human Rights Watch, Truth and Justice Can't Wait: Human Rights Developments in Libya Amid Institutional Obstacles (2009), 1-9.
} 
country. ${ }^{401}$ It is alleged that both sides of the conflict committed atrocities, including extrajudicial killings, ethnic cleansing, mass rape and sexual violence, misconduct and bombings of civilians. ${ }^{402}$ The atrocities amounting to violations of international human rights and humanitarian law, included violations of the right to freedom from torture, the right to liberty and security of persons, freedom of expression, freedom of assembly, crimes against humanity, and war crimes. ${ }^{403}$ In addition to obligations under customary international law in the human rights and humanitarian law fields, Libya is bound by several human rights treaties that may give rise to obligations erga omnes partes, corresponding to one of the two situations envisaged under Article 48 ARSIWA These include, inter alia, core human rights treaties such as the ICCPR and CAT. ${ }^{404}$

\subsubsection{Security Council Enforcement Measures}

In response to the unfolding situation in Libya, on 25 February 2011, the UN Human Rights Council adopted a resolution that strongly condemned 'the recent gross and systematic human rights violations committed in that country including the indiscriminate armed attacks against civilians, extra-judicial killings, arbitrary arrests, detention and torture of peaceful demonstrators, some of which may also amount to crimes against humanity', calling on Libya to immediately end all human rights violations in the country and establishing an International Commission of Inquiry to investigate all alleged breaches of international human rights law in Libya since February 2011. ${ }^{405}$ The resolution was sponsored by Hungary, on behalf of the EU, with co-sponsorship of the majority of EU member states, Western states, several Eastern European states and a significant number of non-Western states. ${ }^{406}$

\footnotetext{
${ }^{401}$ HRC, Report of the International Commission of Inquiry on Libya (2012).

${ }^{402}$ HRC, Report of the International Commission of Inquiry on Libya (2012).

${ }^{403}$ Dawidowicz (2017), 216-220.

${ }^{404}$ OHCHR, UN Treaty Body Database, Ratification Status for Libya. See UNGA, International Covenant on Civil and Political Rights, 16 December 1966, UNTS, Vol. 999, p. 171 [hereinafter ICCPR]; and UNGA, Convention Against Torture and Other Cruel, Inhuman or Degrading Treatment or Punishment 10 December 1984, UNTS, Vol. 1465, p. 85 [hereinafter CAT].

${ }^{405}$ HRC Res. S-15/1 (2011).

${ }^{406}$ HRC, Report of Human Rights Council in its fifteenth special session (2011), para. 20. On 1 March 2011, the UNGA suspended Libya's membership in the Human Rights Council, see UNGA Res. 65/265 (2011). See UNGA Res. 60/251 (2006); UNGA Res. 66/11 (2011); and UNHRC Res. S-15/1 (2011)
} 
The following day, 26 February 2011, the Security Council adopted resolution 1970 (2011). Acting under Chapter VII of the UN Charter, it deplored 'gross and systematic violations of human rights, including the repression of peaceful demonstrators, expressing deep concern at the deaths of civilians, and rejecting unequivocally the incitement to hostility and violence against the civilian population made from the highest level of the Libyan government', considering that the 'widespread and systematic attacks currently taking place in the Libyan Arab Jamahiriya against the civilian population may amount to crimes against humanity'. ${ }^{407}$ The Security Council took enforcement action by referring the situation in Libya to the ICC and imposing mandatory sanctions, including an arms embargo, travel bans and targeted asset freezes directed against senior regime officials and the family of Colonel Gaddafi. ${ }^{408}$ Following threats of escalated violence against the civilian population in Libya and the failure of the Libyan government to implement resolution 1970 (2011), the Security Council adopted on 17 March resolution 1973 (2011). ${ }^{409}$ Acting under Chapter VII of the UN Charter, the Security Council authorised member states 'to take all necessary measures', including the use of force, 'to protect civilians and the civilian populated areas under threat of attack in the Libyan Arab Jamahiriya'. ${ }^{410}$ NATO subsequently launched Operation Unified Protector in late March 2011, which eventually led to the overthrow of Colonel Gaddafi's regime. ${ }^{411}$ The sanctions were partially withdrawn after the overthrow of the Gaddafi regime. ${ }^{412}$ In its final report to the Human Rights Council on 12 January 2012, the International Commission of Inquiry presented its final report, confirming the violations of international human rights and humanitarian law identified in earlier resolutions, including crimes against humanity and war crimes committed by government forces as a result of policy decisions taken at the highest levels of the Libyan government. ${ }^{413}$

\footnotetext{
${ }^{407}$ UNSCR 1970 (2011) (preamble).

${ }^{408}$ UNSC Res. 1970 (2011).

${ }^{409}$ UNSCR 1973 (2011).

${ }^{410}$ UNSCR 1973 (2011), paras 4, 6 and 8 .

${ }^{411}$ See UNSCR 2016 (2011), terminating the authorization to use force in Libya.

412 See UNSCR 2009 (2011).

${ }^{413}$ HRC, Report of the International Commission of Inquiry on Libya (2012), paras. 264-250.
} 


\subsubsection{Third-Party Countermeasures}

The situation in Libya prompted swift action from the international community, some of which preceded the response at the institutional level by the Security Council. In response to the violent repression of the civilian population in Libya, Switzerland decided on 21 February 2011 to freeze with immediate effect the assets of the Libyan Central Bank as well as several senior Libyan officials involved in the violent repression of the civilian population in Libya, including assets belonging to Colonel Gaddafi. It also imposed travel bans, a civil aviation ban, and an arms embargo. ${ }^{414}$

On 25 February 2011, the US froze the assets of the Libyan Central Bank as well as those of senior Libyan government officials, including Colonel Gaddafi. According to the US decision, the measures were a response to the 'extreme measures [taken] against the people of Libya, including by using weapons of war, mercenaries, and wanton violence against unarmed civilians', including prolonged attacks against the civilian population. $^{415}$ The asset freezes can be analysed in terms of third-party countermeasures, as these measures violate the obligations of Switzerland and the US owed to Libya under customary international law as they are unlawful under general international law and therefore require some form of justification. ${ }^{416}$ At the time, Libya was not party to either the GATT or the WTO, meaning that the trade embargoes are most likely acts of retorsion. ${ }^{417}$

The Council of the League of Arab States decided by unanimous vote on 22 February 2011 to suspend Libya from its membership in the League. ${ }^{418}$ The suspension of membership in the Council is possible under Article 18 of the Pact of the League of Arab States for 'any State that is not fulfilling the obligations resulting from this

\footnotetext{
${ }^{414}$ Swiss Federal Council, Ordonnance instituant des mesures à l'encontre de certaines personnes originaires de la Libye (21 February 2011). The sanctions would be replaced by new decisions implementing UN Security Council measures and EU sanctions, beyond the Security Council sanctions regime, see Swiss Federal Council, Ordonnance instituant des mesures à l'encontre de la Libye (30 March 2011).

${ }^{415}$ The US, Executive Order 13566: Blocking Property and Prohibiting Certain Transactions Related to Libya (25 February 2011).

${ }^{416}$ See Criddle (2013) 590-593.

417 As of May 2019, Libya is in the process of acceding the WTO.

${ }^{418}$ Security Council, Press Statement on Libya (22 February 2011); also UNGA Res. 65/265 (1 March 2011), 'welcoming' the decision of the Arab League; and UNHRC Res. S-15/1 (2011).
} 
Pact'. ${ }^{419}$ However, given that there are no human rights or humanitarian law obligations in the Pact itself, the decision to suspend Libya from its membership in the League is unlawful and can be analysed as a third-party countermeasure taken by each of the states participating in the vote. At the minimum, Arab League member states expressed support for the decision to suspend Libya from its membership in the organisation, which has been understood as an expression of support also for the use of third-party. ${ }^{420}$ The decision to suspend Libya from the League of Arab States was later welcomed by the UN Security Council and the General Assembly. ${ }^{421}$

On 28 February 2011, the Council of the EU adopted a decision implementing resolution 1970 (2011) and imposed its own additional restrictive measures, including a visa ban of an additional 16 persons and asset freezes against 20 Libyan officials believed by the EU to be individually responsible for the violence against Libyan civilians. ${ }^{422}$ In a statement, the Council of the EU cited a press release of 23 February 2011 whereby the EU had expressed grave concern about the situation in Libya and strongly condemned the violence and use of force against civilians and the violent repression of the civilian population. A number of third countries later aligned themselves with the restrictive measures taken by the EU against Libya, including Croatia, the former Yugoslav Republic of Macedonia, Montenegro, Iceland, Albania, Serbia, Liechtenstein and Norway, as well as Armenia and Georgia. ${ }^{423}$ Switzerland later aligned itself with the measures taken by the EU, implementing them 30 March 2011. ${ }^{424}$ The legal issues raised by the asset freezes taken by Switzerland and the US prior to enforcement action by the Security Council under Chapter VII were most likely mooted by the adoption of Resolution 1970 (2011), which implicitly approved the list of targets

\footnotetext{
${ }^{419}$ League of Arab States, Charter of the Arab League (1945).

${ }^{420}$ See Dawidowicz (2017), 217-218.

${ }^{421}$ Security Council, Press Statement on Libya (22 February 2011); see also UNGA Res. 65/265 (2011) (preamble); and HRC Res. S-15/1 (2011).

${ }^{422}$ Council of the European Union, Libya: EU Imposes Arms Embargo and Targeted Sanctions (28 February 2011)

${ }^{423}$ Council of the European Union, Libya: EU Imposes Arms Embargo and Targeted Sanctions (28 February 2011). These measures were amended on 7 June 2011, when the Council, amending its previous Council Decision of 28 February 2011, extended its restrictive measures to six Libyan port authorities, including in Tripoli, Zuara, Zawiyah, Al-Khoms, Ras Lanuf and Brega, see Council of the European Union, Libya: Six Ports Targeted by New EU Sanctions (7 June 2011).

${ }^{424}$ Switzerland, Federal Council, Ordonnance instituant des mesures à l'encontre de la Libye (30 March 2011).
} 
by adopting sanctions with a list of targets almost identical to the measures already adopted by individual states. ${ }^{425}$

\subsubsection{Analysis}

The situation in Libya prompted a rapid response by individual states taking third-party countermeasures and by the Security Council, with the majority of unilateral coercive measures taken prior to Security Council enforcement. These included asset freezes, travel bans, civil aviation bans, as well as trade and arms embargoes, and the decision of the Arab League member states to suspend Libya from its membership in the organisation. The Security Council subsequently adopted Resolution 1970 (2011), imposing similar sanctions to the unilateral coercive measures already adopted by individual states but with no mention of these measures in the resolution. Therefore, most of the legal issues raised by the unilateral coercive measures adopted prior to Security Council enforcement action were likely mooted by the adoption of Resolution 1970 (2011), in particular the asset freezes on designated individuals. The Security Council measures can be understood as implicit approval of the list of individuals already targeted by asset freezes. The EU's sanctions adopted subsequent to Resolution 1970 (2011) not only implemented the mandatory sanctions regime, but also went beyond it by designating a larger number of individuals to be targeted by asset freezes. These measures had significant support from a large number of European states as well as Switzerland. However, despite the EU's broadened sanctions regime, the Security Council did not protest or take action to limit it.

The measures adopted against Libya at the unilateral and institutional levels do not demonstrate any incompatibility in practice. This is illustrated in particular by the content of the Security Council measures, which is in many respects similar, if not identical, to many of the unilateral measures already adopted. In this context, it is interesting to note that several of the states initially adopting unilateral coercive measures also decide on measures in their capacity as member states of the Security Council; the US, for example, is one of the five permanent members with veto power. The political functions and composition of the Security Council may be the reasons why

${ }^{425}$ See Criddle (2013), 610. 
the measures adopted at the unilateral and institutional levels are mostly overlapping without any real issue of incompatibility, indicating that perhaps these measures are even able to strengthen and reinforce one another.

\subsection{Conclusion}

The relationship between third-party countermeasures and Security Council enforcement action under Chapter VII of the UN Charter has so far remained uncertain. The matter is essentially a question of whether responses to breaches of communitarian norms should take place within a unilateral or institutional framework. This also relates to broader questions such as the role of the Security Council in the framework for collective security under the UN Charter. The arguments in favour of the idea that the triggering of Security Council enforcement action under Chapter VII of the UN Charter would preclude individual states from taking unilateral coercive measures in the form of third-party countermeasures seems to be based on the idea of the Security Council as the guardian of community interests. It may be recalled that this is the result of the view of the UN Charter as a 'constitution' for the international community.

The triggering of Security Council enforcement action under Chapter VII of the UN Charter does not in itself end any entitlement to take third-party countermeasures. It is clear on the basis of the relatively ambiguous terms of Article 59 ARSIWA that Charter obligations take priority over other obligations if there is a conflict between them. For third-party countermeasures, the law of state responsibility will remain in operation in parallel to that of the UN Charter even in situations to which the Security Council has responded by taking enforcement action under Chapter VII. In the examined case studies, the use of third-party countermeasures did not come into conflict with Security Council measures, despite that the majority of them were taken concurrently with Security Council action. For example, the third-party countermeasures taken against Libya were almost identical to those later adopted by the Security Council, which can be understood as an implicit approval of coercive measures already adopted by individual states. In the case of Sudan, third-party countermeasures could be maintained in parallel with Security Council enforcement measures for a relatively long period of time without any conflict arising between them. It is also noteworthy that there were no 
protests or other action taken against the third-party countermeasures adopted against Sudan, and that the Security Council did not actively limit their concurrent application. Moreover, the UN Charter itself does not contain any implied limitations on the use of third-party countermeasures. The analogy to the impairment of the right to take measures in self-defence under Article 51 of the UN Charter once the Security Council has occupied itself with a situation seems inappropriate given that there are no textual parallels between countermeasures and the use of force in self-defence. Although the Security Council does not formally act as a procedural safeguard against abuse of thirdparty countermeasures, it is in principle able to do so by taking a legally binding decision that explicitly limits the use of third-party countermeasures. In this case, a state would not be able to take third-party countermeasures, as they would conflict with obligations derivative of the UN Charter. However, while decisions of this nature would fall within its competences, the Security Council has yet to exercise this power.

Third-party countermeasures were taken alongside enforcement measures by the Security Council under Chapter VII of the UN Charter in response to violations of human rights and humanitarian law in both Libya and Sudan, responding to similar situations involving a breach of a communitarian norm also falling within the competences of the Security Council. The absence of protests by the Security Council or of decisions taken to limit the use of third-party countermeasures indicates that there is no incompatibility in practice between third-party countermeasures and Security Council enforcement measures. The supposed incompatibility of third-party countermeasures with Security Council enforcement under Chapter VII of the UN Charter, with fears of undermining the powers of the Security Council and creating chaos in the international legal order, does not appear to have materialised in any meaningful way, at least not in the limited case studies examined in this thesis. Although the two case studies involve third-party countermeasures of different scopes, they have a few features in common: Firstly, the rationale for third-party countermeasures by individual states is relatively broad, responding to the breach of a communitarian norm. Security Council enforcement action, on the other hand, is limited to situations involving a threat to international peace and security. Secondly, the Security Council neither protested nor took decisions to limit the use of third-party countermeasures in the studied cases. Moreover, the broader rationale for third-party 
countermeasures may ensure a more comprehensive (non-forcible) response to breaches of communitarian norms, and can in this sense act to complement collective enforcement measures.

\section{Conclusion}

This thesis has examined the relationship between third-party countermeasures under the law of state responsibility and Security Council enforcement measures under Chapter VII of the UN Charter in the broader context of the enforcement of obligations erga omnes. It is submitted that the right of individual states to take third-party countermeasures is neither precluded nor subject to limitations in response to situations where the Security Council is also exercising its enforcement authority under Chapter VII of the UN Charter. Instead, the right to third-party countermeasures operates in parallel to Security Council enforcement mechanisms. The legal conditions and procedural safeguards that are applicable to countermeasures in general under Articles 49-53 ARSIWA will be applicable by analogy also to third-party countermeasures. It seems that the principle of proportionality will be sufficient to moderate the use of thirdparty countermeasures, in particular where several states are acting or where third-party countermeasures are taken concurrently with Security Council enforcement action. It is interesting that the risks of abuse that were initially highlighted during the drafting process of the law of state responsibility regarding the proposal for 'collective countermeasures' do not appear to have materialised in the actual practice of states. The case studies demonstrate that the use of third-party countermeasures has not come into conflict with the Security Council-mandated sanctions regimes or in any other way undermined their effective application. The rationale for third-party countermeasures is generally been much broader than that of the Security Council. In fact, it seems that third-party countermeasures adopted prior to or concurrently with Security Council measures have reinforced the objectives pursued through the latter. This is illustrated by the Sudan case study in which unilateral coercive measures, some of which likely constituted third-party countermeasures, were maintained in force on basis of a relatively broad rationale of on going violations of human rights and humanitarian law. The Security Council resolution adopted in 1996 on Sudan had a much more narrow 
focus that related to Sudan's alleged support for international terrorism, which is clearly in line with the Security Council's otherwise limited mandate for the maintenance of international peace and security under Article 24 of the UN Charter The international response to the rapidly unfolding situation in Libya also serves to illustrate this point, as the third-party countermeasures adopted prior to any Security Council action were implicitly approved once the Security Council first imposed non-forcible measures under Article 41 of the UN Charter. In the following, some concluding remarks will be offered with regard to each of the arguments explored in the main body chapters.

The relationship between the use of third-party countermeasures and Security Council enforcement action under Chapter VII of the UN Charter raises complex questions of the coexistence and coordination of two distinct bodies of law. One such question is the role of the Security Council within the UN Charter framework for collective security as for the protection of the shared values and interests of the international community. This is fundamentally a question of whether the enforcement of community interests should take place within a unilateral or institutional framework. This is why the emergence of a customary right to third-party countermeasures must be examined not in isolation but in a broader context of the enforcement of norms expressing community interests. The conceptualisation of the UN Charter as a 'constitution' for the international community has led to an emphasis on the central role of the Security Council in taking measures to protect and enforce community interests. The Security Council has assumed this role in practice, drawing on expansive interpretations of what constitutes a threat to the peace under Article 39 of the UN Charter, and has increasingly responded to what are essentially internal situations involving a threat to the peace. In doing so, it has integrated into its finding of fact (a threat to the peace) a finding of law (a breach of international law), with the breach becoming an integral part of the security fabric. The Security Council's responses can therefore be described as a form of collective response to breaches of norms established for the protection of a collective interest, acting on behalf of the international community, centralising the determination of a breach as well as the response to such breaches. However, the competences of the Security Council are significantly limited given that the mandate is of a political nature and that any response to the breach of a communitarian norm must be linked to international peace and security. The lack of effective enforcement action from the Security Council in response 
to recent humanitarian catastrophes in Syria and Myanmar clearly illustrates that even the Security Council's broadened competences under Chapter VII of the UN Charter do not necessarily correspond to all breaches of communitarian norms. As such, the view of the Security Council as the guardian of community interests is problematic and at odds with achieving the effective protection and enforcement of such interests.

The current status in international law of the right to take third-party countermeasures in response to breaches of communitarian norms is linked not only to the emergence of community interests in the form of obligations erga omnes (and to some extent, norms jus cogens), but also to the lack of collective institutional mechanisms for the enforcement of communitarian norms. Third-party countermeasures are a deeply divisive concept of international law, which balance the need for effective enforcement of community interests, on one hand, and the fears of legitimising coercive behaviour and unlawful intervention by third states, on the other. The now substantial body of practice suggests that the right to third-party countermeasures is emerging as a matter of customary international law as a response to gross or well-attested violations of human rights or humanitarian law. If a right to third-party countermeasures is emerging as a right under customary law, both the law of state responsibility and the UN Charter system of collective security now provide for the legal consequences of breaches of norms or obligations expressing community interests. In particular, state practice suggests that there is significant overlap with regard to responses to breaches of communitarian norms, in particular violations of human rights and humanitarian law.

The relationship between third-party countermeasures and Security Council enforcement measures is perhaps best described as two parallel systems of law providing for the legal consequences of the breach of a communitarian norm, insofar as the Security Council interprets a situation as a threat to the peace under Article 39 of the UN Charter. The existence of two parallel systems of enforcement is problematic with regard to the need to preserve the coherence and unity of the international legal order under the UN Charter. This argument was raised also during the drafting process regarding the proposal for a regime of 'collective countermeasures', specifically that the right of third states to take countermeasures would in practice undermine the powers of the Security Council in providing a collective response to breaches of such norms. 
However, neither ARSIWA nor the UN Charter act to limit or preclude entirely the use of third-party countermeasures in situations where they are taken concurrently with Security Council enforcement. In this regard, Article 59 ARSIWA, read together with the supremacy clause in Article 103 of the UN Charter, cannot act to displace the operation of the law of state responsibility in these situations. Moreover, nothing in the structure or terms of the UN Charter appears to place a limit on the use of third-party countermeasures. The analogy to Article 51 of the UN Charter on the right of selfdefence is clearly inappropriate given the lack of textual parallels between the framework for the use of force and the right to take countermeasures under the law of state responsibility. Similarly, the argument that there is an implied limitation under the UN Charter to cease with third-party countermeasures once the Security Council has acted in response to a situation lacks support in the structure or terms of the Charter and is ultimately unsustainable.

State practice of third-party countermeasures confirms that the relationship between third-party countermeasures and Security Council enforcement measures is rarely controversial or even conflicting in the actual practice of states. This is illustrated by the rapid response of the international community to serious violations of human rights and humanitarian law committed in Libya during the uprising and civil war in 2011. In less than one week, multiple third states had adopted unilateral coercive measures, mostly in the form of asset freezes targeting senior officials of the Libyan government and military. The Security Council resolution (1970) that was subsequently adopted authorised the same type of asset freezes and had an almost identical list of targets to the unilateral coercive measures already adopted, indirectly approving the latter and mooting any legal issues raised. In the case of Sudan (and subsequently South Sudan), third-party countermeasures have supplemented and continue to supplement Security Council enforcement measures by operating on a much broader rationale and remaining in force for a significantly longer period of time. The difference in the scope of action between the Security Council and third-party countermeasures indicates that there is not necessarily a conflict between the two, but rather that there is significant overlap in terms of the objectives that they pursue (albeit on the basis of distinct legal rationales). It is noteworthy that the Security Council has so far refrained from exercising its competence to limit the use of third-party countermeasures, acting as an institutional 
safeguard, or otherwise intervened to restrain the use of third-party countermeasures. On the basis of these case studies, there is no indication that the use of third-party countermeasures has contradicted or undermined the enforcement measures taken by the Security Council. This may of course be due to the simple fact that most of the states resorting to third-party countermeasures in response to situations of which the Security Council is seized or actively taking measures are the same states that are members of the Security Council. State practice also appears to confirm the conclusions drawn with regard to the theoretical framework relating to the relationship between third-party countermeasures and Security Council enforcement action under Chapter VII of the UN Charter, namely that their use is not limited by concurrent enforcement measures taken by the Security Council. It must be noted, however, that it is entirely possible that the Security Council would have been more active in taking decisions to limit the use of third-party countermeasures if such measures had been taken by states that were not members of the Council.

The triggering of Security Council enforcement action under Chapter VII of the UN Charter does not in and by itself end any entitlement of third states to take countermeasures in the collective interest. Interestingly, the instances of state practice studied above indicate a relatively uncontroversial relationship between the two, with one enforcement mechanism supplementing or perhaps even reinforcing the other. In conclusion, the 'uncertain' relationship between third-party countermeasures and Security Council enforcement measures appears largely to be a theoretical problem with risks that have not materialised in practice. 


\section{Bibliography}

\section{Literature}

Acevedo. D-E. (1984), 'The U.S Measures Against Argentina Resulting from the Malvinas Conflict', American Journal of International Law, Vol. 78, No. 2, 323-344.

Akehurst, M. (1970), 'Reprisals by Third States', British Yearbook of International Law, Vol. 44, No. 1, 1-18.

Alland, D. (2002), 'Countermeasures of General Interest', European Journal of International Law, Vol. 13, No. 5, 1221-1239.

Alland. D. (2010), 'The Definition of Countermeasures', in Crawford, J., Pellet, A., and Olleson, S. (eds.), The Law of International Responsibility, Oxford: Oxford University Press, 1127-1136.

Allot, P. (1990), Eunomia: A New Order for a New World, Oxford: Oxford University Press.

Annacker, C. (1994), 'The Legal Régime of Erga Omnes Obligations in International Law, Austrian Journal of Public International Law, Vol. 46, No. 2, 113 ff.

Arangio-Ruiz, G. (2000), 'Article 39 of the ILC Draft Articles on State Responsibility', 80 Rivista di diritto internazionale 747.

Benvenisti, E., and Nolte, G. (2018), 'Introduction', in Benvenisti, E., and Nolte, G. (eds.), Community Interests Across International Law, Oxford: Oxford University Press, $3-16$. 
Besson, S. (2018), 'Community Interests in International Law', in Benvenisti, E., and Nolte, G. (eds.), Community Interests Across International Law, Oxford: Oxford University Press, 36-49.

Bird, A. (2011), 'Third State Responsibility for Human Rights Violations', European Journal of International Law, Vol. 21, No. 4, 883-890.

Boisson de Chazournes, L. (1998), 'Les résolutions des organes des Nations Unies, et en particulier celles du Conseil de sécurité en tant que source du droit international humanitaire', in Condorelli, L., la Rosa, A-M., Scherrer, S. (eds.), Les Nations Unies et le droit international humanitaire, Paris: Pedone, 149-173.

Bollecker-Stern, B. (1973), Le préjudice dans la théorie de la responsabilité internationale, Paris, Pubications de la Revue générale de droit international public.

Brownlie, I., (2008), Principles of Public International Law, 7 ed., Oxford: Oxford University Press.

Calamita, N.J. (2009), 'Sanctions, Countermeasures, and the Iranian Nuclear Issue', in Vanderbilt Journal of Transnational Law, Vol. 42, No. 5, 1437-1441.

Cannizzaro, E. (2001), 'The Role of Proportionality in the Law of International Countermeasures', in European Journal of International Law, Vol. 12, No. 5, 889-916.

Cassese, A., (2005), International Law, 2 ed., Oxford, Oxford University Press.

Charney, J.I. (1989), ‘Third-State Remedies in International Law', in Michigan Journal of International Law, Vol. 10, No. 1, 57-101.

Crawford, J. (2012), Brownlie's Principles of Public International Law, Oxford: Oxford University Press. 
Crawford, J. (2013), State Responsibility: The General Part, Cambridge: Cambridge University Press.

Criddle, E.J. (2013), 'Humanitarian Financial Intervention', in European Journal of International Law, Vol. 24, No. 2, 583-615.

Darcy, S. (2015), 'Retaliation and Reprisal', in Weller, M. (ed.), The Oxford Handbook on the Use of Force in International Law, Oxford: Oxford University Press, 879-892.

Dawidowicz, M. (2006), 'Public Law Enforcement without Public Law Safeguards? An Analysis of State Practice on Third-Party Countermeasures and their Relationship to the UN Security Council', British Yearbook of International Law, Vol. 77, No. 1, 333-418.

Dawidowicz, M. (2017), Third-Party Countermeasures in International Law, Cambridge: Cambridge University Press.

De Hoogh, A. (1996), Obligations Erga Omnes and International Crimes: A Theoretical Inquiry into the Implementation and Enforcement of the International Responsibility of States, London: Kluwer International Law.

Dupont, P-E. (2012), 'Countermeasures and Collective Security: The Case of the EU Sanctions Against Iran', in Journal of Conflict and Security Law, Vol. 17, 301-336.

Dupuy, P-M. (1993), 'Sécurité collective et organisation de la paix', in Revue générale de droit international, Vol. 97, No. 3, 617-627.

Dupuy, P-M. (1997), 'The Constitutional Dimension of the Charter of the United Nations Revisited', in Max Planck Yearbook of United Nations Law, Vol. 1, 1-34.

Elagab, O.Y. (1988), The Legality of Non-Forcible Counter-measures in International Law, Oxford: Clarendon Press. 
Feichtner, I. (2007), 'Community Interest', in Max Planck Encyclopaedia of International Law.

Friedmann, W.G. (1964), The Changing Structure of International Law, London: Stevens.

Frowein, J. (1994), 'Reactions by Not Directly Affected States to Breaches of Public International Law', 248 Recueil des Cours de l'Académie de Droit International, 345437.

Frowein, J. (2001), 'Implementation of Security Council Resolutions', in GowllandDebbas, V. (ed.), United Nations Sanctions and International Law, The Hague: Kluwer Law International.

Gaja, G. (1989), 'Obligations Erga Omnes, International Crimes and Jus Cogens: A Tentative Analysis of Three Related Concepts', in Weiler, J.H., Cassese, A., and Spinedi, M., (eds.), International Crimes of State: A Critical Analysis of the ILC's Draft Article 19 on State Responsibility, Berlin/New York: Walter de Gruyter, 151-160.

Gaja, G. (1993), 'Réflexions sur le rôle du Conseil de sécurité dans le nouvel ordre mondial à propos des rapports entre maintien de la paix et crimes internationaux des Etats', in Revue générale de droit international public, Vol. 97(2), 297-310.

Gaja, G. (2010), 'The Concept of an Injured State', in Crawford, J., Pellet, A., Olleson, S. (eds.), The Law of International Responsibility, Oxford: Oxford University Press, 941-948.

Gaja, G. (2013), 'The Protection of General Interests in the International Community', 364 Recueil des Cours de l'Académie de Droit International, 9-185.

Gowlland-Debbas, V. (1990), Collective Responses to Illegal Acts in International Law, Dordrecht: Nijhoff. 
Gowlland-Debbas, V. (2001a), 'UN Sanctions and International Law: An Overview', in Gowlland-Debbas, V. (ed.), United Nations Sanctions and International Law, The Hague: Kluwer Law International, 1-29.

Gowlland-Debbas. V. (2001b), 'The Functions of the United Nations Security Council in the International Legal System', in Byers, M. (ed.), The Role of Law in International Politics: Essays in International Relations and International Law, Oxford: Oxford University Press, 277-313.

Gowlland-Debbas, V. (2010), 'Responsibility and the United Nations Charter', in Crawford, J., Pellet, A., Olleson, S. (eds.), The Law of International Responsibility, Oxford: Oxford University Press, 115-138.

Gray, C. (2018), International Law and the Use of Force, 4 ed., Oxford: Oxford University Press.

Greig, D. (2002), “'International Community”, "Interdependence” and All That... Rhetorical Correctness?', in Kreijen, G., et al., State, Sovereignty, and International Governance, Oxford: Oxford University Press, 521-603.

Hakimi, M. (2014), 'Unfriendly Unilateralism', in Harvard International Law Journal, Vol. 55, No. 1, 105-150.

Higgins, R. (1963), The Development of International Law through the Political Organs of the United Nations, London: Royal Institute of International Affairs.

Hillgruber, C. (2006), 'The Right of Third States to Take Countermeasures', in Tomuschat, C., and Thouvenin, J-M. (eds.), The Fundamental Rules of the International Legal Order: Jus Cogens and Obligations Erga Omnes, Leiden/Boston: Martinus Nijhoff Publishers, 265-294.

Human Rights Watch (2009), Truth and Justice Can't Wait: Human Rights Developments in Libya Amid Institutional Obstacles. 
Hutchinson, D.N. (1988), 'Solidarity and Breaches of Multilateral Treaties', in British Yearbook of International Law, Vol. 59, No. 1, 151-215.

Hutchinson, D.N. (2015), 'The Doctrinal Method: Incorporation Interdisciplinary Methods in Reforming the Law', Erasmus Law Review, Vol. 8, No. 3, 130-139.

IDI (2005), Fifth Commission: Obligations and Rights Erga Omnes in Internatoinal Law/Cinquième Commission: Les obligations et les droits erga omnes en droit international, http://www.idiiil.org/app/uploads/2017/06/2005_kra_01_en.pdf (accessed 20 May 2019).

Jessup, P.C. (1948), A Modern Law of Nations: An Introduction, New York: MacMillan.

Kadelblach, S. (2006), 'Jus Cogens, Obligations Erga Omnes and Other Rules - The Identification of Fundamental Norms', in Tomuschat, C., and Thouvenin, J-M. (eds.), The Fundamental Rules of the International Legal Order: Jus Cogens and Obligations Erga Omnes, Leiden/Boston: Martinus Nijhoff Publishers, 21-40.

Katselli Proukaki, E. (2010), The Problem of Enforcement in International Law: Countermeasures, the Non-Injured State and the Idea of International Community, London/New York: Routledge.

Kelsen, H. (1950), The Law of the United Nations: A Critical Analysis of Its Fundamental Problems, London: Institute of World Affairs

Kirchner, S. (2004), 'Relative Normativity and the Constitutional Dimension of International Law: A Place for Values in the International Legal System?', in German Law Journal, Vol. 5, No. 1, 47-64.

Kolb, R. (2017), The International Law of State Responsibility: An Introduction, Cheltenham: Edward Elgar Publishing. 
Koskenniemi, M. (2001), 'Solidarity Measures: State Responsibility as a New International Order?', British Yearbook of International Law, Vol. 72, No. 1, 337-356.

Lesaffre, H. (2010), 'Circumstances Precluding Wrongfulness in the ILC Articles on State Responsibility: Countermeasures', in Crawford, J., Pellet, A., Olleson, S. (eds.), The Law of International Responsibility, Oxford: Oxford University Press, 469-474.

Macdonald, R. ST. J. (1986), 'The Charter of the United Nations and the Development of Fundamental Principles of International Law', in Cheng, B., and Brown, E.D. (eds.), Contemporary Problems of International Law. Essays in Honour of Georg Schwarzenberger on his Eightieth Birthday, London: Stevens, 196-215.

Macdonald, R. ST. J. (1987), 'Fundamental Norms in Contemporary International Law', Canadian Yearbook of International Law, Vol. 25, 115-149.

Macdonald, R. ST. J. (1993), in Dominicé, C., and Lalive, P. (eds.), Etudes de droit international en l'honneur de Pierre Lalive, Bâle: Helbing und Lichtenhahn, 275 ff.

Orakhelashvili, A. (2006), Peremptory Norms in International Law, New York: Oxford University Press.

Palchetti, E. (2014), 'Consequences for Third States as a Result of an Unlawful Use of Force', in Weller, M. (ed.), The Oxford Handbook of the Use of Force in International Law, Oxford: Oxford University Press, 1224 ff.

Perrin de Brichambaut, M. (2001), 'The Role of the United Nations Security Council in the International Legal System', in Byers, M. (ed.), The Role of Law in International Politics: Essays in International Relations and International Law, Oxford: Oxford University Press, 269-276.

Ragazzi, M. (1997), The Concept of International Obligations Erga Omnes, Oxford: Clarendon. 
Sachariew, K. (1988), 'State responsibility for multilateral treaty violations: identifying the "injured State" and its legal status', in Netherlands International Law Review, vol. 35, No. 3, 273-289.

Sarooshi, D. (1999), The United Nations and the Development of Collective Security: The Delegation by the UN Security Council of its Chapter VII Powers, Oxford: Clarendon.

Schachter, O. (1982), 'International Law in Theory and Practice: General Course in Public International Law', 178 Recueil des Cours de l'Académie de Droit International, 9-395.

Shaw, M. (2017), International Law, 8 ed., Cambridge: Cambridge University Press.

Sicilianos, L-A. (1990), Les réactions décentralisées à l'illicite: Des contre-mesures à la légitime défense, Paris: Librairie générale de droit et de jurisprudence.

Sicilianos, L-A. (2002), 'The Classification of Obligations and the Multilateral Dimension of the Relations of International Responsibility', in European Journal of International Law, Vol. 13, No. 5, 1127-1145.

Sicilianos, L-A. (2005), 'La codification des contre-mesures par la Commission du droit international', in Revue belge de droit international, 2005/1-2, 484-490.

Sicilianos, L-A. (2010), 'Countermeasures in Response to Grave Violations of Obligations Owed to the International Community', in Crawford, J., Pellet, A., Olleson, S. (eds.), The Law of International Responsibility, Oxford: Oxford University Press, $1137-1148$

Simma, B. (1989), 'Bilateralism and community interest in the law of State responsibility', in Rosenne, S., Dinstein, Y., and Tabory, M. (eds.), International Law at 
a Time of Perplexity: Essays in Honour of Shabtai Rosenne, Dordrecht: Nijhoff, 821844.

Simma, B. (1994), 'From Bilateralism to Community Interest in International Law', 250 Recueil des Cours de l'Académie de Droit International, 217-384.

Simma, B. (2007), 'Human Rights and State Responsibility', in Reinisch, A., and Kriebaum, U. (eds.), The Law of International Relations - Liber Amicorum Hanspeter Neuhold, Utrecht: Eleven International Publishing, 359 ff.

Simma, B. (2012), The Charter of the United Nations: A Commentary, Vols. 1-3, 3 ed., Oxford: Oxford University Press.

Spinedi, M. (1989), 'International Crimes of State: The Legislative History', in Weiler, J.H., Cassese, A., and Spinedi, M., (eds.), International Crimes of State: A Critical Analysis of the ILC's Draft Article 19 on State Responsibility, Berlin/New York: Walter de Gruyter, 7-140.

Tams, C. (2005), Enforcing Obligations Erga Omnes in International Law, Cambridge: Cambridge University Press.

Tams, C. (2011), 'Individual States as Guardians of Community Interests', in Fastenrath, U., Simma, B., (eds.), From Bilateralism to Community Interest: Essays in Honour of Bruno Simma, Oxford: Oxford University Press, 379 ff.

Tomuschat, C. (1993), 'Obligations Arising for States Without or Against their Will', 241 Recueil des Cours de l'Académie de Droit International, 195-374.

Tsagourias, N., and White, N.D. (2013), Collective Security: Theory, Law and Practice, Cambridge: Cambridge University Press. 
Ugarte, B.S., and Genser, J. (2014), 'Evolution of the Security Council's Engagement on Human Rights', in Ugarte, B.S., and Genser, J. (eds.), The United Nations Security Council in the Age of Human Rights, New York: Cambridge University Press, 3-32.

Villalpando, S. (2005), L'émergence de la communauté internationale dans la responsabilité des Etats, Geneva: Graduate Institute Publications.

Villalpando, S. (2010), 'The Legal Dimension of the International Community: How Community Interests are Protected in International Law', in European Journal of International Law, Vol. 21, No. 2, 387-419.

Von Geusau F.A.M (1999), 'Recent and Problematic: The Imposition of Sanctions by the UN Security Council', in Van Genugten, W.J.M., de Groot, G.A (eds.), United Nations Sanctions: Effectiveness and Effects, Especially in the Field of Human Rights: A Multi-Disciplinary Approach, Antwerpen: Intersentia Law Publishers, $1 \mathrm{ff}$.

Weil, P. (1983), 'Towards Relative Normativity in International Law', American Journal of International Law, Vol. 77, $413 \mathrm{ff}$.

Wellens, K. (2003), 'The UN Security Council and New Threats to the Peace: Back to the Future', in Journal of Conflict and Security Law, Vol. 8, No. 1, 15-70.

White, N.D, and Abass, A. (2003), 'Countermeasures and Sanctions', in Evans, M. (ed.), International Law, Oxford: Oxford University Press.

Zoller, E. (1984), Peacetime Unilateral Remedies: An Analysis of Countermeasures, Dobbs Ferry/New York: Transnational Publishers.

\section{Electronic Sources}

Al-Jazeera, 'Arab League Decides to Suspend Syria', Al-Jazeera, https://www.aljazeera.com/news/middleeast/2011/11/201111121342948333.html, 13 November 2011 (accessed 23 May 2019). 
Al-Jazeera, 'Russia Marks Five Years Since Annexation of Ukraine's Crimea', $A l$ Jazeera, https://www.aljazeera.com/news/2019/03/russia-marks-years-annexationukraine-crimea-190318072208651.html, 18 March 2019 (accessed 23 May 2019).

BBC News, 'East Ukraine Separatists Seek Union with Russia', $B B C$ News, https://www.bbc.com/news/world-europe-27369980, 12 May 2014 (accessed 23 May 2019).

'Clinton Calls for "Friends of Democratic Syria" to Unite Against Bashar al-Assad', Syal, R., The Guardian, https://www.theguardian.com/world/2012/feb/05/hillaryclinton-syria-assad-un, 5 February 2012 (accessed 23 May 2019).

Human Rights Watch, 'World Report 2011: Libya (Events of 2010)', https://www.hrw.org/world-report/2011/country-chapters/libya (accessed 23 May 2019).

OHCHR, UN Treaty Body Database, Ratification Status for Libya, available https://tbinternet.ohchr.org/_layouts/15/TreatyBodyExternal/Treaty.aspx?CountryID=99 \&Lang=EN (accessed 2019-05-22).

'Organization of Islamic Cooperation Suspends Syria', 1sharif, A., Reuters, https://www.reuters.com/article/us-syria-crisis-islamic-summit/organization-of-islamiccooperation-suspends-syria-idUSBRE87E19F20120816, 16 August 2012 (accessed 23 May 2019).

'Russian “invasion” of Crimea Fuels Fear of Ukraine Conflict', Walker, S., Salem, H., and MacAskill, E., The Guardian, https://www.theguardian.com/world/2014/feb/28/russia-crimea-white-house, 1 March 2014 (accessed 23 May 2019).

United States Congressional Research Service, 'Venezuela: Overview of U.S. Sanctions' (2019), https://fas.org/sgp/crs/row/IF10715.pdf, (accessed 22 May 2019). 


\section{Official Documents and Reports}

\section{International Law Commission (ILC)}

\section{Official Documents}

ILC, Draft Articles on Responsibility of States for Internationally Wrongful Acts, November 2001, Supplement No. 10 (A/56/10).

ILC, Draft Articles on Responsibility of States for Internationally Wrongful Acts, with Commentaries (2001).

ILC, Report of the Drafting Committee: State Responsibility - Draft Articles Provisionally Adopted by the Drafting Committee on Second Reading, A/CN.4/L.600 (21 August 2000).

ILC, Report of the International Law Commission at its Fifty-Eigth Session (1 May-9 June and 3 July-11 August 2006), UN Doc. A/61/10 (2006).

ILC, Report on the Fragmentation of International Law: Difficulties Arising from the Diversification and Expansion of International Law, UN Doc. A/CN.4/L.682 (13 April 2006).

YbkILC (1958), Vol. II.

YbkILC (1992), Vol. I.

YbkILC (2000), Vol. I.

YbkILC (2000), Vol. II(1).

YbkILC (2000), Vol. II(2).

YbkILC (2001), Vol. I.

YbkILC (2001), Vol. II(1).

YbkILC (2001), Vol. II(2). 
Reports by Special Rapporteurs to the ILC

Ago, R., Fifth Report on State Responsibility, by Mr. Roberto Ago, Special Rapporteur, UN Doc. A/CN.4/291 and Add. 1-2 (1976).

Arangio-Ruiz, G., Fourth Report on State Responsibility, by Mr. Arangio-Ruiz, Special Rapporteur, UN Doc. A/CN.4/444, Add. 1 and 2-3 (1992).

Arangio-Ruiz, G. Seventh Report on State Responsibility, by Mr. Arangio-Ruiz, Special Rapporteur, UN Doc. A/CN.4/469 and Add. 1-2 (1995).

Arangio-Ruiz, G., Third Report on State Responsibility, by Mr. Gaetano Arangio-Ruiz, Special Rapporteur, UN Doc. A/CN.4/440 and Add. 1 (1993).

Crawford, J., First Report on State Responsibility, by Mr. James Crawford, Special Rapporteur, UN Doc. A/CN.4/490 and Add. 1-7 (1998).

Crawford, J. Fourth Report on State Responsibility, by Mr. James Crawford, Special Rapporteur, UN Doc. A/CN.4/517 and Add. 1 (2001).

Crawford, J., Third Report on State Responsibility, by Mr. James Crawford, Special Rapporteur, UN Doc. A/CN.4/507 and Add. 1-4 (2000).

Riphagen, W., Sixth Report on State Responsibility, by Mr. Riphagen, Special Rapporteur UN Doc. A/CN.4/389 (1985).

Riphagen, W., Third Report on State Responsibility, by Mr. Riphagen, Special Rapporteur UN Doc. A/CN.4/354 and Add. 1-2 (1982). 


\section{United Nations (UN)}

\section{General Assembly (UNGA)}

UNGA, In Larger Freedom: Towards Development, Security and Human Rights for All, UN Doc. A/59/2005 (21 March 2005).

UNGA, Sixth Committee, Statement by Algeria (UN Doc. A/C.6/55/SR.18, 2).

UNGA, Sixth Committee, Statement by Argentina (UN Doc. A/C.6/55/SR.15, 10).

UNGA, Sixth Committee, Statement by Austria (UN Doc. A/CN.4/515, 88-92).

UNGA, Sixth Committee, Statement by Australia (UN Doc. A/C.6/55/SR.16, 7).

UNGA, Sixth Committee, Statement by Botswana (UN Doc. A/C.6/55/SR/15, 10).

UNGA, Sixth Committee, Statement by Brazil (UN Doc. A/C.6/56/SR.16, 2).

UNGA, Sixth Committee, Statement by Cameroon (UN Doc. A/C.6/55/SR.24, 11).

UNGA, Sixth Committee, Statement by Chile (UN Doc. A/C.6/55/SR.17, 8).

UNGA, Sixth Committee, Statement by China (UN Docs. A/CN.4/515, 69-70;

A/C.6/56/SR.11, 10).

UNGA, Sixth Committee, Statement by Colombia (UN Doc. A/C.6/56/SR.16, 7).

UNGA, Sixth Committee, Statement by Costa Rica (UN Doc. A/C.6/55/SR.17, 11).

UNGA, Sixth Committee, Statement by Cuba (UN Doc. A/C.6/55/SR.18, 11).

UNGA, Sixth Committee, Statement by Finland, on behalf of the Nordic countries (UN Doc. A/C.6/56/SR.11, 5).

UNGA, Sixth Committee, Statement by France (UN Doc. A/CN.4/515/Add.2, 15-16).

UNGA, Sixth Committee, Statement by Germany (UN Doc. A/C.6/55/SR.14, 10).

UNGA, Sixth Committee, Statement by Greece (UN Doc. A/CN.6/55/SR.17, 14).

UNGA, Sixth Committee, Statement by India (UN Doc. A/C.6/55/SR.15, 5-6).

UNGA, Sixth Committee, Statement by Iran (UN Doc. A/C.6/55/SR.15, 3).

UNGA, Sixth Committee, Statement by Israel (UN Doc. A/C.6/55/SR.15, 5).

UNGA, Sixth Committee, Statement by Italy (UN Doc. A/C.6/55/SR.16, 5, para. 28).

UNGA, Sixth Committee, Statement by Japan (UN Doc. A/CN.4/515, 79).

UNGA, Sixth Committee, Statement by Jordan (UN Doc. A/C.6/55/SR.18, 4).

UNGA, Sixth Committee, Statement by Libya (UN Doc. A/C.6/55/SR.22, 8).

UNGA, Sixth Committee, Statement by Mexico UN Doc. A/CN4/515/Add.1, 9-10). 
UNGA, Sixth Committee, Statement by Mongolia (UN Doc. A/C.6/56/SR.14, 9).

UNGA, Sixth Committee, Statement by Morocco (UN Doc. A/C.6/56/SR.11, 7).

UNGA, Sixth Committee, Statement by the Netherlands (UN Doc. A/CN.4/515, 87).

UNGA, Sixth Committee, Statement by New Zealand (UN Doc. A/C.6/56/SR.11, 8).

UNGA, Sixth Committee, Statement by Poland (UN Docs. A/CN.4/515/Add.2, 18-19, A/C.6/55/SR.18).

UNGA, Sixth Committee, Statement by Russia (UN Doc. A/C.6/55/SR.18, 9).

UNGA, Sixth Committee, Statement by Slovenia (UN Doc. A/C.6/55/SR.18, 6).

UNGA, Sixth Committee, Statement by South Africa, on behalf of SADC (UN Doc. A/C.6/56/SR.12)

UNGA, Sixth Committee, Statement by Switzerland (UN Doc. A/C.6/55/SR.18/, 14).

UNGA, Sixth Committee, Statement by Tanzania (UN Doc. A/C.6/55/SR.14, 9).

UNGA, Sixth Committee, Statement by the United States (UN Doc. A/CN.4/515, 52)

UNGA, Sixth Committee, Topical Summary of Government Comments in the Sixth Committee (UN Doc. A/CN.4/472/Add. 1).

UNGA, Statement of President Bush before the General Assembly at its $59^{\text {th }}$ Session, UN Doc. A/59/PV.3 (21 September 2004).

\section{Human Rights Council (UNHRC)}

UNHRC, Report of the Independent International Fact-Finding Mission on Myanmar, UN Doc. A/HRC/39/64 (12 September 2018).

UNHRC Report of the International Commission of Inquiry on Libya, UN Doc. A/HRC/19/68 (8 March 2012).

UNHRC Report of the Working Group on the Universal Periodic Review: Libyan Arab Jamahiriya, UN Doc. A/HRC/16/15 (4 January 2011). 
UNHRC, Report of the Special Rapporteur on the Negative Impact of Unilateral Coercive Measures on the Enjoyment of Human Rights, Idriss Jazairy, UN Doc. A/HRC/30/45 (10 August 2015).

UNHRC, Report of the Human Rights Council on its Fifteenth Special Session, UN Doc. A/HRC/S-15/1 (25 February 2011).

Office of the High Commissioner for Human Rights (OHCHR)

OHCHR, 'Darker and More Dangerous: High Commissioner Updates the Human Rights Council on Human Rights Issues in 40 Countries (Opening Statement by Zeid Ra'ad Al Hussein, United Nations High Commissioner for Human Rights, at the $36^{\text {th }}$ Session of the Human Rights Council, Geneva, 11 September 2017), https://www.ohchr.org/EN/NewsEvents/Pages/DisplayNews.aspx?NewsID=22041\&La $\underline{n g I D}=\mathrm{E},($ accessed 23 May 2019).

OHCHR, Deepening Crisis in Darfur: Two Months after the Darfur Peace Agreement: An Assessment, Fourth Periodic Report of the United Nations High Commissioner for Human Rights on the Situation of Human Rights in the Sudan (2006), https://www.ohchr.org/Documents/Countries/4thOHCHRjuly25final.pdf (accessed 23 May 2019).

OHCHR, Human Rights Violations in the Bolivarian Republic of Venezuela: A Downward Spiral with no End in Sight, Report by the Office of the United Nations Higher Commissioner for Human Rights (June 2018), https://www.ohchr.org/Documents/Countries/VE/VenezuelaReport2018_EN.pdf (accessed 23 May 2019).

OHCHR, Report on the Human Rights Situation in Ukraine (15 April 2014), https://www.ohchr.org/EN/Countries/ENACARegion/Pages/UAReports.aspx (accessed 23 May 2019). 
OHCHR, Second Periodic Report of the United Nations High Commissioner for Human Rights on the Human Rights Situation in Sudan (27 January 2006), https://www.ohchr.org/Documents/Countries/sudanjanuary06.pdf (accessed 23 May 2019).

Security Council (UNSC)

UNSC, Security Council Press Statement on Libya, SC/10180-AFR-2120 (22 February 2011), https://www.un.org/press/en/2011/sc10180.doc.htm (accessed 23 May 2019). UNSC, Statement by the President of the Council, S/PRST/2017/22 (6 November 2017) (accessed 23 May 2019), https://undocs.org/S/PRST/2017/22 (23 May 2019).

\section{European Union (EU)}

Council of the European Union, Common Position 2004/31/CFSP of 9 January 2004 concerning the imposition of an embargo on arms, munitions and military equipment on Sudan [2004] OJ L 6.

Council of the European Union, Common Position 2005/411/CFSP of 30 May 2005 concerning restrictive measures against Sudan repealing Common Position 2004/31/CFSP [2005] OJ L 139.

Council of the European Union, Common Position 2004/510/CFSP of 10 June 2004 amending Common Position 2004/31/CFSP concerning the imposition of an embargo on arms, munitions and military equipment on Sudan [2004] OJ L 209/28.

Council of the European Union, Decision 94/165/CFSP of 15 March 1994 on the common position defined on the basis of Article J.2 of the Treaty on European Union concerning the imposition of an embargo on arms, munitions and military equipment on Sudan [1994] OJ L 075.

Council of the European Union, Decision 2011/273/CFSP of 9 May 2011 concerning restrictive measures against Syria [2011] OJ L 121/11. 
Council of the European Union, Decision 2011/423/CFSP of 18 July 2011 concerning restrictive measures against Sudan and South Sudan and repealing Common Position 2005/411/CFSP.

Council of the European Union, Decision 2011/782/CFSP of 1 December 2011 concerning restrictive measures against Syria and repealing Decision 2011/273/CFSP [2011] OJ L 319/56.

Council of the European Union, Decision 2014/145/CFSP of 17 March 2014 concerning restrictive measures in respect of actions undermining of threatening the territorial integrity, sovereignty and independence of Ukraine [2014], OJ L 78/16.

Council of the European Union, Decision 2017/2074 of 13 November 2017 concerning restrictive measures in view of the situation in Venezuela [2017] OJ L 295/60.

Council of the European Union, Decision 2018/2054 of 21 December 2018 amending Decision 2013/184/CFSP concerning restrictive measures against Myanmar/Burma; Council Implementing Regulation (EU) 2018/2053 [2018] OJ LI 327/5.

Council of the European Union, Decision 2019/678 of 29 April 2019 amending Decision 2013/184/CFSP concerning restrictive measures against Myanmar/Burma [2019] OJ L 114/18.

Council of the European Union, Declaration by the High Representative on Behalf of the EU on the Alignment of Certain Countries with Council Decision concerning Restrictive Measures against Myanmar/Burma, 7 February 2019, OJ L 3271/5.

Council of the European Union, Implementing Decision 2014/151/CFSP of 21 March 2014 implementing Decision 2014/145/CFSP concerning restrictive measures in respect of actions undermining of threatening the territorial integrity, sovereignty and independence of Ukraine [2014] OJ 86/30. 
Council of the European Union, Implementing Regulation 2019/672 of 29 April 2019 implementing Regulation (EU) No 401/2013 concerning restrictive measures in respect of Myanmar/Burma [2019] OJ L 114/1.

Council of the European Union, Libya: EU Imposes Arms Embargo and Targeted Sanctions, 28 February 2011, OJ L 7081/11.

Council of the European Union, Libya: Six Ports Targeted by New EU Sanctions, 7 June 2011, OJ L 11221/11.

Council of the European Union, Myanmar/Burma: EU Adds 7 Military and Border Guard Police Officials Responsible for Human Rights Violations to Sanctions List, 21 December 2018, OJ L 822/18.

Council of the European Union, Press Release, 3 March 2014, OJ 7196/14, https://www.consilium.europa.eu/media/28852/141294.pdf (accessed 23 May 2019).

Council of the European Union, Regulation No 838/2005 of 30 May 2005 amending Regulation No 131/2004 concerning certain restrictive measures in respect of Sudan.

Council of the European Union, Regulation 2017/2063 of 13 November 2017 concerning restrictive measures in view of the situation in Venezuela [2017] OJ L $295 / 21$.

\section{Other Documents and Statements}

Russian Federation, Ministry of Foreign Affairs, 'Comment by the Russian Ministry of Foreign Affairs regarding the Continuing Anti-Russian Sanctions of the United States', 30 July 2014, www.mid.ru/brp_4.nsf/main_eng (accessed 20 May 2019).

Statement of G-7 Leaders on Ukraine, 12 March 2014, available at https://www.g7germany.de/Content/DE/_Anlagen/G7_G20/G7-leaders_statement-ukr2014-03-12-eng nn=1282094.html (accessed 23 May 2019). 
Switzerland, Federal Council, Ordonnance instituant des mesures à l'encontre de la Libye, decision of 30 March 2011.

Switzerland, Federal Council, Ordonnance instituant des mesures à l'encontre de certaines personnes originaires de la Libye, decision of 21 February 2011.

United States, The President, Executive Order 13067: Blocking Sudanese Government Property and Prohibiting Transactions with Sudan, 3 November 1997.

United States, The President, Executive Order: 13566: Blocking Property and Prohibiting Certain Transactions Related to Libya, 25 February 2011.

United States, The President, Executive Order 13850: Blocking Property of Additional Persons Contributing to the Situation in Venezuela, 1 November 2018.

United States, The President, Executive Order 13857: Taking Additional Steps to Address the National Emergency With Respect to Venezuela, 25 January 2019.

United States, Department of the Treasury, Press Releases, Treasury Sanctions Commanders and Units of the Burmese Security Forces for Serious Human Rights Abuses, 17 August 2018, https://home.treasury.gov/news/press-releases/sm460 (accessed 23 May 2019).

United States, White House Press Release, Statement by the President on New Sanctions Related to Russia', 11 September 2014, https://obamawhitehouse.archives.gov/thepress-office/2014/09/11/statement-president-new-sanctions-related-russia (accessed 22 May 2019). 


\section{UN Resolutions}

\section{General Assembly (UNGA)}

40/64 Policies of Apartheid of the Government of South Africa (UN Doc. $\mathrm{A} / \mathrm{RES} / 40 / 64)$.

47/142 The Situation in the Sudan (UN Doc. A/RES/47/142).

48/147 Situation of Human Rights in the Sudan (UN Doc. A/RES/48/147).

49/198 Situation of Human Rights in the Sudan (UN Doc. A/RES/49/198).

50/197 Situation of Human Rights in the Sudan (UN Doc. A/RES/50/197).

51/112 Situation of Human Rights in the Sudan (UN Doc. A/RES/51/112).

60/1 2005 World Summit Outcome (UN Doc. A/RES/60/1).

60/251 Human Rights Council (UN Doc. A/RES/60/251).

63/308 The Responsibility to Protect (UN Doc. A/RES/63/308).

65/265 Suspension of the Rights of Membership of the Libyan Arab Jamahiriya in the Human Rights Council (UN Doc. A/RES/65/265).

66/11 Restoration of the Rights of Membership of Libya in the Human Rights Council (UN Doc.A/RES/66/11).

68/262 Territorial Integrity of Ukraine (UN Doc. A/RES/68/262).

71/205 Situation of Human Rights in the Autonomous Republic of Crimea and the City of Sevastopol (Ukraine) (UN Doc. A/RES/71/205).

72/248 Situation of Human Rights in Myanmar (UN Doc. A/RES/72/248).

73/263 Situation of Human Rights in the Autonomous Republic of Crimea and the City of Sevastopol, Ukraine (UN Doc. A/RES/73/263).

377 (V) Uniting for Peace (UN Doc. A/RES/377(V)).

\section{Security Council (UNSC)}

161 B The Congo Question (UN Doc. S/RES/161 B).

$418 \quad$ South Africa (UN Doc. S/RES/418).

733 Somalia (UN Doc. S/RES/733).

757 Bosnia and Herzegovina (Un Doc. S/RES/757).

$788 \quad$ Liberia (UN Doc. S/RES/788). 
The Expansion of the Mandate of the UN Assistance Mission for Rwanda and Imposition of An Arms Embargo on Rwanda (UN Doc. S/RES/918).

1044 Letter Dated 9 January 1996 from the Permanent Representative of Ethiopia to the United Nations Addressed to the President of the Security Council Concerning the Extradition of the Suspects wanted in the Assassination Attempt on the Life of the President of the Arab Republic of Egypt in Addis Ababa (UN Doc. S/RES/1044).

1054 Letter Dated 9 January 1996 from the Permanent Representative of Ethiopia to the United Nations Addressed to the President of the Security Council Concerning the Extradition of the Suspects wanted in the Assassination Attempt on the Life of the President of the Arab Republic of Egypt in Addis Ababa (UN Doc. S/RES/1054).

1070 Letter Dated 9 January 1996 from the Permanent Representative of Ethiopia to the United Nations Addressed to the President of the Security Council Concerning the Extradition of the Suspects wanted in the Assassination Attempt on the Life of the President of the Arab Republic of Egypt in Addis Ababa (UN Doc. S/RES/1070).

1372 Sudan (UN Doc. S/RES/1372).

1591 Reports of the Secretary-General on the Sudan (UN Doc. S/RES/1591).

1674 Protection of Civilians in Armed Conflict (UN Doc. S/RES/1674).

$1970 \quad$ Libya $(\mathrm{S} / \mathrm{RES} / 1970)$.

1973 Libya (UN Doc. S/RES/1973).

2009 Libya (UN Doc. S/RES/2009).

2016 The Situation in Libya (UN Doc. S/RES/2016).

2206 Sudan and South Sudan (UN Doc. S/RES/2206).

S/2014/189

Albania, Australia, Austria, Belgium, Bulgaria, Canada,

Croatia, Cyprus, Czech Republic, Denmark, Estonia,

Finland, France, Georgia, Germany, Greece, Hungary,

Iceland, Ireland, Italy, Japan, Latvia, Liechtenstein, 
Lithuania, Luxembourg, Malta, Montenegro, Netherlands, New Zealand, Norway, Poland, Portugal, Republic of Moldova, Romania, Slovakia, Slovenia, Spain, Sweden, Turkey, Ukraine, United Kingdom of Great Britain and Northern Ireland and United States of America: Draft Resolution.

S/2019/186 United States of America: Draft Resolution

S/2019/190 (2019) Russian Federation: Draft Resolution.

\section{Human Rights Council (HRC)}

34/22 Situation of Human Rights in Myanmar (UN Doc. A/HRC/RES/34/22).

39/1 Promotion and Protection of Human Rights in the Bolivarian Republic of Venezuela (UN Doc. A/HRC/RES/39/1).

39/2 Situation of Human Rights of Rohingya Muslims and Other Minorities in Myanmar (UN Doc. A/HRC/RES/39/2)

S-15/1 Situation of Human Rights in the Libyan Arab Jamahiriya (UN Doc.

A/HRC/RES/S-15/1).

\section{Commission of Human Rights (CHR)}

1994/79 Situation of Human Rights in the Sudan.

1995/77 Situation of Human Rights in the Sudan.

1996/73 Situation of Human Rights in the Sudan.

1997/59 Situation of Human Rights in the Sudan.

1998/67 Situation of Human Rights in the Sudan.

1999/15 Situation of Human Rights in the Sudan.

2000/27 Situation of Human Rights in the Sudan.

2005/82 Situation of Human Rights in the Sudan. 


\section{International Treaties and Conventions}

GATS, General Agreement on Trade in Services, 15 April 1994, Marrakesh Agreement Establishing the World Trade Organisation, Annex 1B, 1869 UNTS 183, 33 I.L.M 1167 (1994)

GATT 1994, General Agreement on Tariffs and Trade, 15 April 1994, Marrakesh Agreeement Establishing the World Trade Organisation, Annex 1A, 1867 UNTS 187, 33 I.L.M 1153 (1994)

League of Arab States, Charter of the Arab League, 22 March 1945 (1945).

Organisation of African Unity (OAU), Charter of the Organization of African Unity, 25 May 1963 (1963).

$\mathrm{UN}$, Charter of the United Nations and the Statute of the International Court of Justice, 24 October 1945, 1 UNTS XVI (1945).

UN, Vienna Convention on the Law of Treaties, 23 May 1969, UNTS Vol. 1155, 331 (1969).

UNGA Convention on the Prevention and Punishment of the Crime of Genocide, 9 December 1948, United Nations, Treaty Series, Vol. 78, 277 (1948).

UNGA, International Covenant on Civil and Political Rights, 16 December 1966, UNTS, Vol. 999, p. 171 (1966).

UNGA, Convention Against Torture and Other Cruel, Inhuman or Degrading Treatment or Punishment, 10 December 1984, UNTS, Vol. 1465, p. 85 (1984). 


\section{Table of Cases}

\section{International Court of Justice (ICJ)}

Application of the Convention on the Prevention and Punishment of the Crime of Genocide (Bosnia and Herzegovina v. Serbia and Montenegro), Judgment, I.C.J. Reports 2007, 43.

Barcelona Traction, Light and Power Company, Limited, Judgment, I.C.J. Reports, 1970, 3 .

Certain Expenses of the United Nations (Article 17, paragraph 2, of the Charter), Advisory Opinion of 20 July 1962, I.C.J. Reports 1962, 151, at 168.

East Timor (Portugal v. Australia), Judgment, I.C.J. Reports 1995, 90.

Gabcikovo-Nagymaros Project (Hungary/Slovakia), Judgment, I.C.J. Reports 1997, 7.

Legal Consequences of the Construction of a Wall in the Occupied Palestinian Territory, Advisory Opinion, I.C.J. Reports 2004, 136.

Military and Paramilitary Activities in and against Nicaragua (Nicaragua v. United States of America), Merits, Judgment, I.C.J. Reports 1986, 14.

Questions of Interpretation and Application of the 1971 Montréal Convention arising from the Aerial Incident at Lockerbie (Libyan Arab Jamahiriya v. United States), Preliminary Objections, Judgment, I.C.J. Reports 1998, 115.

Questions Relating to the Obligation to Prosecute or Extradite (Belgium v. Senegal), Judgment, I.C.J. Reports 2012, 422. 
Reparation for injuries suffered in the service of the United Nations, Advisory Opinion, I.C.J. Reports 1949, 174.

Reservations to the Convention on Genocide, Advisory Opinion, I.C.J. Reports 1951, 15.

United States Diplomatic and Consular Staff in Tehran (United States v. Iran) Judgment, I.C.J. Reports 1980, 3.

\section{Permanent Court of International Justice (PCIJ)}

S.S Wimbledon (United Kingdom et al., v. Germany), Judgment (1923), PCIJ Series A no 1 ICGJ 235 (PCIJ 1923), 17 August 1923, League of Nations, Permanent Court of International Justice (PCIJ).

\section{International Arbitral Awards}

Case Concerning the Air Service Agreement of 27 March 1946 between the United States of America and France, Arbitral Award of 91978.

Corn Products International Inc. v. Mexico, ICSID Case No. ARB(AF)/04/01, Decision on Responsibility, 15 Jan. 2008.

Island of Las Palmas (Netherlands, United States), arbitral award of 4 April 1928, UN Rep International Arbitral Awards, ii. 